\title{
RECOVERY OF WATER FROM BOILER FLUE GAS
}

FINAL TECHNICAL REPORT

January 1, 2006 to September 30, 2008

\author{
by \\ Edward Levy \\ Harun Bilirgen \\ Kwangkook Jeong \\ Michael Kessen \\ Christopher Samuelson \\ Christopher Whitcombe
}

Report Issued: December, 2008

DOE Award Number DE-FC26-06NT42727

\author{
Energy Research Center \\ Lehigh University \\ 117 ATLSS Drive \\ Bethlehem, PA 18015
}




\section{DISCLAIMER}

"This report was prepared as an account of work sponsored by an agency of the United States Government. Neither the United States Government nor any agency thereof, nor any of their employees, makes any warranty, express or implied, or assumes any legal liability or responsibility for the accuracy, completeness, or usefulness of any information, apparatus, product, or process disclosed, or represents that its use would not infringe privately owned rights. Reference herein to any specific commercial product, process, or service by trade name, trademark, manufacturer, or otherwise does not necessarily constitute or imply its endorsement, recommendation, or favoring by the United States Government or any agency thereof. The views and opinions of authors expressed herein do not necessarily state or reflect those of the United States Government or any agency thereof." 


\section{ACKNOWLEDGEMENTS}

In addition to the U.S. Department of Energy, the authors of this report are extremely grateful to Alstom Power, the Pennsylvania Infrastructure Technology Alliance and Lehigh University for supporting this project. 


\section{ABSTRACT}

This project dealt with use of condensing heat exchangers to recover water vapor from flue gas at coal-fired power plants. Pilot-scale heat transfer tests were performed to determine the relationship between flue gas moisture concentration, heat exchanger design and operating conditions, and water vapor condensation rate. The tests also determined the extent to which the condensation processes for water and acid vapors in flue gas can be made to occur separately in different heat transfer sections. The results showed flue gas water vapor condensed in the low temperature region of the heat exchanger system, with water capture efficiencies depending strongly on flue gas moisture content, cooling water inlet temperature, heat exchanger design and flue gas and cooling water flow rates. Sulfuric acid vapor condensed in both the high temperature and low temperature regions of the heat transfer apparatus, while hydrochloric and nitric acid vapors condensed with the water vapor in the low temperature region. Measurements made of flue gas mercury concentrations upstream and downstream of the heat exchangers showed a significant reduction in flue gas mercury concentration within the heat exchangers. A theoretical heat and mass transfer model was developed for predicting rates of heat transfer and water vapor condensation

and comparisons were made with pilot scale measurements. Analyses were also carried out to estimate how much flue gas moisture it would be practical to recover from boiler flue gas and the magnitude of the heat rate improvements which could be made by recovering sensible and latent heat from flue gas. 


\section{TABLE OF CONTENTS}

$\underline{\text { Page }}$

CHAPTER 1: INTRODUCTION

Background 1

Objectives and Scope of Project $\quad 4$

CHAPTER 2: CONDENSING HEAT EXCHANGER APPARATUS AND 5 PILOT-SCALE TEST SITES

CHAPTER 3: MEASUREMENTS OF WATER VAPOR CAPTURE RATES 9

$\begin{array}{ll}\text { Bare Tube Heat Exchangers } & 9\end{array}$

Tests with Combination of Bare Tube and Fin Tube Heat Exchangers 13

Comparison of Bare Tube and Fin Tube Heat Exchanger Performance 18

CHAPTER 4: CAPTURE OF ACIDS AND MERCURY FROM FLUE GAS 21

$\begin{array}{ll}\text { Sulfuric Acid Capture } & 21\end{array}$

Oil-Fired Test Data $\quad 21$

Coal-Fired Test Data 25

Nitrate and Chloride Capture

$\begin{array}{ll}\text { Oil-Fired Test Data } & 27\end{array}$

CHAPTER 5: THEORETICAL MODEL OF WATER VAPOR CONDENSATION 35 AND COMPARISON TO PILOT-SCALE DATA]

CHAPTER 6 - ESTIMATES OF MAXIMUM RECOVERABLE

FLUE GAS MOISTURE AND POTENTIAL HEAT RATE IMPROVEMENTS

$\begin{array}{ll}\text { INTRODUCTION } & 44\end{array}$

GROUP I HEAT EXCHANGERS: COLD BOILER FEEDWATER 46 AS HEAT SINK

Introduction 46

Supercritical Steam Turbine Cycle with FG-FWH Heat Recovery $\quad 46$

Analysis of Flue Gas Feedwater Heater: (Group I Heat Exchangers) 50

Steam Turbine Cycle Analysis: Supercritical Case 54

Steam Turbine Cycle with Flue Gas Feedwater Heater 56 
Page

Subcritical Steam Turbine Cycle 58

GROUP II HEAT EXCHANGERS: INLET COMBUSTION AIR AS 63 HEAT SINK

$\begin{array}{ll}\text { Introduction } & 63\end{array}$

GROUP III HEAT EXCHANGERS: USE OF ADDITIONAL AMBIENT 68 AIR AS HEAT SINK

ESTIMATED FRACTION OF COOLING TOWER MAKEUP WATER PROVIDED BY SYSTEM OF CONDENSING HEAT EXCHANGERS

$\begin{array}{lr}\text { NOMENCLATURE } & 80\end{array}$

$\begin{array}{lc}\text { ACRONYMS AND DEFINITIONS } & 81\end{array}$ 


\section{LIST OF FIGURES}

$\underline{\text { Figure }}$

$\underline{\text { Page }}$

1-1 Typical Makeup Cooling Water Requirements of a Coal-Fired Power Plant (Ref. 1).

1-2 Potential Locations of Flue Gas Heat Exchangers for Coal-Fired Units With and Without $\mathrm{SO}_{2}$ Scrubbers.

1-3 Applications of Condensing Heat Exchangers for Pretreating Boiler

Flue Gas Prior to Processing by Flue Gas $\mathrm{CO}_{2}$ Scrubbers and for Removing Moisture from Concentrated Streams of $\mathrm{CO}_{2}$ Prior to $\mathrm{CO}_{2}$ Compression.

2-1 Elevation View of Test Apparatus with Three Bare Tube Heat Exchangers (HX4 to HX6) in the Water Vapor Condensation Zone.

2-2 Elevation View of Test Apparatus with One Bare Tube Heat Exchanger (HX4) and One Fin Tube Exchanger (HXFIN) in the Water Vapor Condensation Zone.

2-3 Photograph of Two Bare Tube Heat Exchanger Bundles.

2-4 Fin-Tube Heat Exchanger Bundle Mounted in Duct.

3-1 Axial Variation of Flue Gas Water Vapor Concentration: Coal Tests. 10 Flue Gas Flows from Left to Right in Graph.

3-2 Axial Variations of Flue Gas Temperature: Coal Tests. Flue Gas Flows from Left to Right in Graph.

3-3 Axial Variations of Cooling Water Temperature: Coal Tests. Cooling Water Flows from Right to Left in Graph.

3-4 Water Vapor Capture Efficiency vs. Inlet Cooling Water

Temperature: Coal Tests.

3-5 Water Capture Efficiency vs. Cooling Water Flow Rate: Coal Tests.

3-6 Variation of Total Water Capture Efficiency with Inlet Cooling Water Temperature: Tests at Oil-Fired Boiler.

3-7 Total Water Capture Efficiency vs. Flue Gas Flow Rate: Tests at Oil-Fired Boiler. 


\section{LIST OF FIGURES (continued)}

Figure

Page

3-8 Effect of Inlet Cooling Water Temperature on Distribution of Water Vapor Mole Fraction through Combined Bare Tube-Fin Tube Heat Exchanger Array.

3-9 Effect of Inlet Cooling Water Temperature on Distribution of Flue Gas Temperature Through Combined Bare Tube-Fin Tube Heat Exchanger Array.

3-10 Effect of Inlet Cooling Water Temperature on Distribution of Cooling Water Temperature Through Combined Bare Tube-Fin Tube Heat Exchanger Array.

3-11 Effect of Inlet Cooling Water Temperature on Total Water Vapor Capture Efficiency in Combined Bare Tube-Fin Tube Heat Exchanger Array.

3-12 Effect of Dry Flue Gas Flow Rate on Total Water Vapor Capture Efficiency in Combined Bare Tube-Fin Tube Heat Exchanger Array.

3-13 Temporal Variation of Inlet Flue Gas Water Vapor Volume Fraction During Tests Over Range of Flue Gas Flow Rates.

Effect of Inlet Moisture Fraction on Total Water Capture

Efficiency. Fin-Tube Array with $74^{\circ} \mathrm{F}$ Inlet Water Temperature.

3-15 Variation of Heat Transfer to cooling Water with Inlet Cooling Water Temperature. Comparison between Bare Tube and Fin Tube Heat Transfer Bundles.

3-16 Comparison of Rates of Heat Transfer to Cooling Water in HXFin, HX6 and HX5.

3-17 Comparison of Water Vapor Capture Efficiencies of HXFin, $\mathrm{HX} 6$ and $\mathrm{HX} 5$.

4-1 Axial Variations of Flue Gas Sulfuric Acid Concentration. Oil Test Data with $48^{\circ} \mathrm{F}$ Inlet Cooling Water Temperature.

4-2 Axial Variation of Average Flue Gas Sulfuric Acid Concentration. Oil Test Data with $48^{\circ} \mathrm{F}$ Inlet Cooling Water Temperature. 


\section{LIST OF FIGURES (continued)}

Figure

$\underline{\text { Page }}$

4-3 Axial Variation of Water Vapor Concentration. Oil Test Data

22 with $48^{\circ} \mathrm{F}$ Inlet Cooling Water Temperature.

4-4 Axial Variations of Flue Gas and Tube Wall Temperatures. Oil

Test Data with $48^{\circ} \mathrm{F}$ Inlet Cooling Water Temperature.

4-5 Water Vapor Dew Point Temperature vs. Volumetric Concentration.

24

4-6 Sulfuric Acid Dew Point Temperature vs. Acid and Water Vapor Volumetric Concentrations.

4-7 Axial Variations of Flue Gas Sulfuric Acid Concentration. Coal Test Data with $76^{\circ} \mathrm{F}$ and $100^{\circ} \mathrm{F}$ Inlet Cooling Water Temperatures.

4-8 Axial Variation of Water Vapor Concentration. Coal Test Data with $77^{\circ} \mathrm{F}$ Inlet Cooling Water Temperature.

4-9 Axial Variations of Flue Gas and Tube Wall Temperatures. Coal

Test Data with $77^{\circ} \mathrm{F}$ Inlet Cooling Water Temperature.

4-10 Nitrate Concentration in Condensed Water Vapor from Heat

Exchangers HX4 to HX6. Oil Test Data with Inlet Cooling Water

Temperatures from 42 to $90^{\circ} \mathrm{F}$.

4-11 Nitrate Flow Rates from Heat Exchangers HX4 to HX6 versus

Tube Wall Temperature. Oil Test Data with Inlet Cooling Water

Temperatures from 42 to $90^{\circ} \mathrm{F}$.

4-12 Chloride Concentration in Condensed Water Vapor from Heat

Exchangers HX4 to HX6. Oil Test Data with Inlet Cooling Water

Temperatures from 42 to $90^{\circ} \mathrm{F}$.

4-13 Chloride Flow Rates from Heat Exchangers HX4 to HX6 versus

Tube Wall Temperature. Oil Test Data with Inlet Cooling Water Temperatures from 42 to $90^{\circ} \mathrm{F}$.

4-14 $\mathrm{HCl}$ and $\mathrm{HNO}_{3}$ Dew Points versus Acid and Water Vapor Volumetric Concentrations. From Reference 4.

4-15 Nitrate Concentration in Condensed Water Vapor from Heat Water Temperature. 


\section{LIST OF FIGURES (continued)}

Figure

$\underline{\text { Page }}$

4-16 Nitrate Flow Rates from Heat Exchangers HX3 to HX6 versus

31

Tube Wall Temperature. Coal Test Data with $77^{\circ} \mathrm{F}$ Inlet Cooling Water Temperature.

4-17 Chloride Concentration in Condensed Water Vapor from Heat

Exchangers HX3 to HX6. Coal Test Data with $77^{\circ} \mathrm{F}$ Inlet Cooling Water Temperature.

4-18 Chloride Flow Rates from Heat Exchangers HX3 to HX6 versus Tube Wall Temperature. Coal Test Data with $77^{\circ} \mathrm{F}$ Inlet Cooling Water Temperature.

4-19 Variations of Flue Gas Mercury Concentrations at Inlet and Exit of Condensing Heat Exchanger System as Test Series Progressed. Coal Test Data with $70^{\circ} \mathrm{F}$ Inlet Cooling Water Temperature.

4-20 Variations of Flue Gas Mercury Concentrations at Inlet and Exit of Condensing Heat Exchanger System as Test Series Progressed. Coal Test Data with $100^{\circ} \mathrm{F}$ Inlet Cooling Water Temperature.

4-21 Variations in Flue Gas Mercury Concentrations at Inlet and Exit of Condensing Heat Exchanger System as Test Series Progressed. Coal Test Data with $70^{\circ} \mathrm{F}$ and $100^{\circ} \mathrm{F}$ Inlet Cooling Water Temperature.

5-1 Sketch of Heat and Mass Transfer Processes in Condensing Heat Exchanger.

5-2 Sketch of Smooth Wall Tube Heat Exchanger Apparatus.

5-3 Comparison of Measure and Predicted Water Condensation Rates. Inlet Cooling Water at $90.7^{\circ} \mathrm{F}$ and $1450 \mathrm{lbm} / \mathrm{hr}$.

5-4 Inlet Cooling Water at $87.8^{\circ} \mathrm{F}$ and $620 \mathrm{lbm} / \mathrm{hr}$. Comparison of Measured and Predicted Water Condensation Rates.

5-5 Inlet Cooling Water at $77.4^{\circ} \mathrm{F}$ and $820.3 \mathrm{lbm} / \mathrm{hr}$. Comparison of Measured and Predicted Water Condensation Rates.

5-6 Inlet Cooling Water at $99.6^{\circ} \mathrm{F}$ and $869.8 \mathrm{lbm} / \mathrm{hr}$. Comparison of Measured and Predicted Water Condensation Rates. 


\section{LIST OF FIGURES (continued)}

Figure

Page

5-7 Variation of Water Vapor Condensation Efficiency with Inlet

39 Cooling Water Temperature.

5-8 Variation of Water Vapor Condensation Efficiency with Cooling

39 Water Flow Rate.

5-9 Variation of Water Vapor Condensation Efficiency with Flue Gas Flow Rate (Inlet Cooling Water at 75.8 to $78^{\circ} \mathrm{F}$ ).

5-10 Variation of Water Vapor Condensation Rate with Flue Gas Flow Rate. (Inlet Cooling Water at $100^{\circ} \mathrm{F}$ ).

5-11 Predicted and Measured Condensation Efficiency. Coal-Fired Test Data.

5-12 Predicted and Measured Condensation Efficiency: Natural Gas-Fired Test Data.

5-13 Predicted and Measured condensation Efficiency: Oil-Fired Test Data. 43

5-14 Effect of Flow Rate Ratio of Cooling Water to Flue Gas on Water Vapor Condensation Efficiency for $0.5<\mathrm{m}_{\mathrm{cw}} / \mathrm{m}_{\mathrm{fg}}<3.5$.

6-1 Potential Locations of Flue Gas Heat Exchangers for Coal-Fired Units With and Without $\mathrm{SO}_{2}$ Scrubbers.

6-2 Flue Gas Cooling Process with Three Groups of Heat Exchangers.

6-3 Steam Turbine Cycle Diagram for Supercritical Unit.

6-4 Detailed View of Feedwater Heaters 1 to 3 with Extraction Flows $\mathrm{G}$ to $\mathrm{E}$.

6-5 Flue Gas Feedwater Heat Exchanger. 50

6-6 Heat Exchanger Effectiveness as a Function of Normalized Heat Exchanger Surface Area.

6-7 Comparison of Flue Gas Water Capture Efficiencies for FG-FWH Heat Exchanger Effectiveness Values of 0.85 and 1.00 .

6-8 Simplified Diagram of Steam Turbine Cycle. 


\section{LIST OF FIGURES (continued)}

$\underline{\text { Figure }}$

$\underline{\text { Page }}$

6-9 Steam Turbine Cycle with Flue Gas Feedwater Heater.

56

6-10 Comparison of Changes in Turbine Cycle Heat Rate with Flue Gas

58

Water Fraction with Heat Exchanger Effectiveness Values of

0.85 to 1.00 .

6-11 Steam Turbine Cycle Diagram of Subcritical Unit.

6-12 Flue Gas Feedwater Heat Exchanger - Subcritical Cycle

6-13 Variation of Flue Gas Water Capture Efficiency with Inlet

Flue Gas Moisture Fraction. Subcritical Steam Cycle with $\varepsilon=0.85$ and 1.00 .

6-14 Variation of Turbine Cycle Heat Rate Improvement with Inlet Flue Gas Moisture Fraction. Subcritical Turbine Cycle with $\varepsilon=0.85$ and 1.00 .

6-15 Effect of Feedwater Inlet Temperature on Water Capture Efficiency for an Effectiveness of 0.85.

6-16 Effect of Feedwater Inlet Temperature on Turbine Cycle Heat Rate for an Effectiveness of 0.85.

6-17 Process Diagram Showing FG-FWH and FG-AHX1 Integrated With Boiler and Auxiliary Components.

6-18 FG-AHX1 Impacts on Summer Water Capture Efficiency with FG-FWH $\varepsilon=0.85$.

6-19 FG-AHX1 Impacts on Summer Water Capture Efficiency with FG-FWH $\varepsilon=1.00$.

6-20 FG-AHX1 Impacts on Winter Water Capture Efficiency with with FG-FWH $\varepsilon=0.85$.

6-21 FG-AHX1 Impacts on Winter Water Capture Efficiency with FG-FWG $\varepsilon=1.00$.

6-22 Effects on Inlet Flue Gas Moisture Fraction on Overall Water Vapor Capture Efficiency. 


\section{LIST OF FIGURES (continued)}

\section{$\underline{\text { Figure }}$}

Page

6-23 Effects on Inlet Flue Gas Moisture Fraction on Overall Unit Heat Rate Improvement.

6-24 Flue Gas Cooling Process with FG-FWH, FG-AXH1 and

68 FG-AHX2 Heat Exchangers Integrated with Boiler and Auxiliary Components.

6-25 Total Water Capture Efficiency as a Function of Inlet Flue Gas Moisture Fraction for Summer and Winter Conditions

6-26 Ratio of Cooling Air Mass Flow Rate for AHX2 to Combustion Air Mass Flow Rate.

6-27 Estimated Fraction of Cooling Tower Makeup Water Provided by Condensing Heat Exchangers. 


\section{LIST OF TABLES}

$\underline{\text { Table }}$

$\underline{\text { Page }}$

2-1 Heat Transfer Surface Area of each Heat Exchanger $\quad 7$

2-2 Typical Ultimate Analysis of Coal Used at the Test Site 8

3-1 Process Conditions for Fin Tube Tests with Variable Cooling Water 14 Temperature: Coal-Fired Boiler

3-2 Comparison of Rates of Heat Transfer to Cooling Water with Fin

Tube and Bare Tube Heat Exchangers

6-1 As-Received Coal Properties and Flue Gas Composition 51

6-2 Effect of Coal Type on Performance of Flue Gas Feedwater

51

Heater: Supercritical FG-FWH ASPEN Calculations with $\varepsilon=0.85$.

6-3 Supercritical FG-FWH ASPEN Calculations with $\varepsilon=1.00$

6-4 Supercritical Unit Component Performance $\quad 55$

6-5 Comparison of ASPEN Plus Steam Cycle Performance 55

Values to Turbine Kit Values

6-6 Effect of Flue Gas Feedwater Heater on Supercritical Steam $\quad 57$

Turbine Extraction Flow Rates

6-7 Effects of FG-FWH on Supercritical Turbine Cycle Power and 57 Heat Rate

6-8 Water Capture Results from the Three Flue Gas Heat Exchanger

69 Groups

6-9 Flue Gas-to-Air Heat Exchanger Results 


\section{EXECUTIVE SUMMARY}

As the U.S. population grows and demand for electricity and water increase, coal-fired power plants located in some parts of the country will find it increasingly difficult to obtain the large quantities of water needed to maintain operations. Most of the water used in a thermoelectric power plant is used for cooling, and DOE has been focusing on possible techniques to reduce the amount of fresh water needed for cooling. This project examined the technical issues involved in use of condensing heat exchangers for capturing water vapor from boiler flue gas. The project involved pilot scale water vapor condensation tests, an evaluation of the heat rate and emissions cobenefits of installing these at coal-fired power plants, and estimates of the maximum recoverable flue gas moisture as a function of flue gas moisture content.

Pilot-scale flue gas water vapor condensation tests were performed at a coalfired power plant and at a boiler which fires fuel oil and natural gas. The water-cooled heat exchangers included bare tube heat exchanger bundles in the high temperature end of the heat exchanger system and both bare tube and fin tube heat exchanger bundles in the low temperature end. The test data show that process parameters such as cooling water temperature and flow rate, flue gas flow rate and flue gas water vapor content, affect flue gas water vapor condensation rates. While the design of the heat exchanger system tested in this project was not optimized, the results suggest that water capture efficiencies greater than 70 percent will be possible for some process conditions. However, for other combinations of process conditions, much lower water capture efficiencies are to be expected. Both experimental and theoretical results show the ratio of cooling water to flue gas flow rates can have a large effect on rate of water capture, with capture efficiency decreasing steadily with a decrease in flow rate ratio to levels of capture efficiency from 10 to 30 percent for values of flow rate ratio between 0.5 and 1.0 .

Sorbent trap measurements were made of the mercury concentrations at the inlet and outlet of the condensing heat exchanger system. The data indicate approximately a 60 percent decrease in flue gas mercury concentration occurred due to the condensing heat exchangers. Measurements of sulfuric acid vapor and water vapor in the flue gas were made in both oil-fired and coal-fired tests. The regions over which the sulfuric acid and water vapor condensed were quite distinct in the oil-fired tests. The majority of the acid condensed in the high temperature heat exchanger while water vapor condensation was limited to the three low temperature heat exchangers. In contrast, acid condensation occurred within all of the heat exchangers in the coal-fired tests, with the water vapor condensation, once again, limited to the low temperature heat exchangers. The reasons for the differences between the location of sulfuric acid condensation in the coal and oil-based flue gas will be investigated by the project team in a follow-on investigation. Finally, the data also showed that hydrochloric and nitric acids condensed with water vapor in the low temperature heat exchangers.

A first-principle model of the heat and mass transfer processes occurring in the heat exchanger system was developed and used to compute both water vapor condensation rates in individual heat exchangers and the total rate of water vapor 
condensation. Comparisons with measured data for a range of process conditions show agreement between measurements and predictions to within a few percent.

Use of heat exchangers in the back end of the boiler to recover water vapor from flue gas also provides opportunities to improve unit heat rate. Under the right conditions, sensible and latent heat transferred from the flue gas can be used to preheat boiler feedwater, thus reducing the steam turbine extraction flows to the feedwater heaters and thereby reducing unit heat rate. Other heat exchangers can be used to preheat combustion air, thereby increasing boiler efficiency and reducing heat rate. The potential magnitude of the combined heat rate impact was determined from analyses carried out for a steam turbine cycle with an inlet feedwater temperature to the flue gas feedwater heater of $87.1^{\circ} \mathrm{F}$. The analyses were performed for four U.S. coals, ranging from a relatively low-moisture bituminous coal to a high-moisture lignite. The resulting estimated combined improvement in unit heat rate was in the 1.8 to 3.9 percent range. At the same time, the estimated combined water vapor capture efficiency ranged from 10 to 34 percent. Both estimated heat rate improvement and water capture efficiency increased with increasing inlet flue gas moisture concentration, decreasing inlet combustion air temperature, and increasing heat exchanger effectiveness.

Theoretical analyses were also performed in which three separate groups of heat exchangers were used to cool the flue gas and condense flue gas moisture: one for preheating boiler feedwater, a second for preheating inlet combustion air and a third for condensing much of the remaining flue gas moisture through use of low temperature ambient air as a heat sink. For the case of high moisture North Dakota lignite, the analyses predict overall water capture efficiencies of 88 percent for winter operation and 71 percent for summer operation. Overall capture efficiency depends strongly on flue gas moisture content or equivalently on coal moisture content, and the predicted winter and summer capture efficiencies decrease to 80 percent (winter operation) and 50 percent (summer operation) for low moisture bituminous coals.

Based on U.S. annual average cooling tower makeup water needs, the estimated percentage of cooling tower makeup water which could be provided by condensing heat exchangers was found to 6.4 to 8.5 percent for units firing low moisture bituminous coals, 14.1 to 16.5 percent for units firing Powder River Basin coals and 22.2 to 24.8 percent for units firing high moisture U.S. lignite coals.

There are potential applications of condensing heat exchangers in carbon capture and sequestration systems (CCS). Amine and ammonia $\mathrm{CO}_{2}$ scrubbers require inlet flue gas temperatures below $100^{\circ} \mathrm{F}$ for efficient operation, and the types of heat exchangers described in this report are candidates for use in pretreating boiler flue gas before it flows into a $\mathrm{CO}_{2}$ scrubber. In addition, it is expected that in most cases the concentrated streams of $\mathrm{CO}_{2}$ produced by post-combustion $\mathrm{CO}_{2}$ scrubber systems and by oxyfuel boilers will be compressed to over 2000 psia before being transported by pipeline to geologic sequestration sites. These concentrated streams of $\mathrm{CO}_{2}$ will contain high concentrations of water vapor which should be separated from the $\mathrm{CO}_{2}$ before compression, and here, too, condensing heat exchangers of the type described in this report may have an important role to play. 


\section{CHAPTER 1}

\section{INTRODUCTION}

\section{Background}

As the U.S. population grows and demand for electricity and water increase, power plants located in some parts of the country will find it increasingly difficult to obtain the large quantities of water needed to maintain operations. Most of the water used in a thermoelectric power plant is used for cooling, and DOE has been focusing on possible techniques to reduce the amount of fresh water consumed for cooling (Figure $1-1)$.

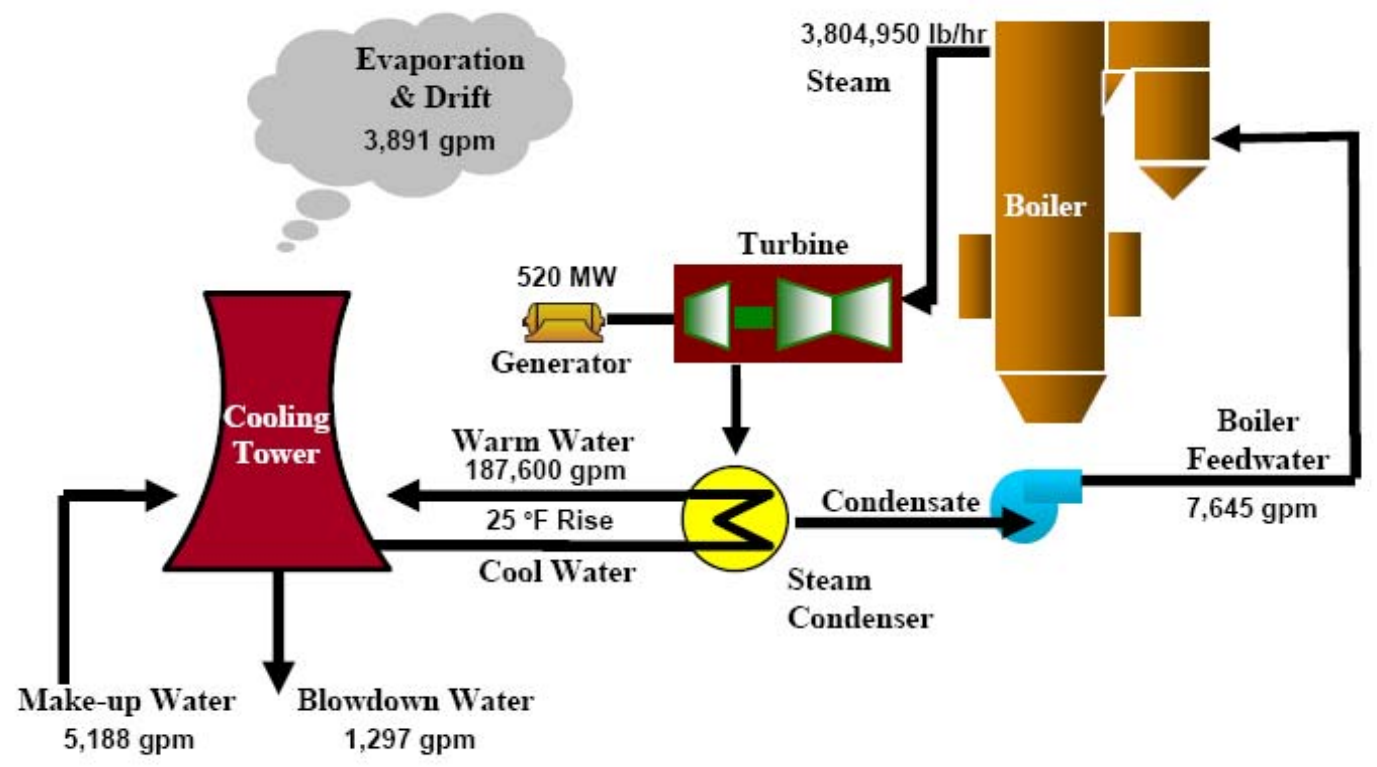

Figure 1-1: Typical Makeup Cooling Water Requirements of a Coal-Fired Power Plant (Ref 1).

DOE is also placing emphasis on recovery of usable water from sources not generally considered, such as mine water, water produced from oil and gas extraction, and water contained in boiler flue gas. This report deals with use of condensing heat exchangers to recover water vapor from boiler flue gas, and it describes the heat rate and emissions co-benefits of using these at coal-fired power plants.

The moisture in boiler flue gas comes from three sources ... fuel moisture, water vapor formed from the oxidation of fuel hydrogen, and water vapor carried into the boiler 
with combustion air. The amounts of $\mathrm{H}_{2} \mathrm{O}$ vapor in flue gas depend heavily on coal rank. Calculations for $585 \mathrm{MW}$ pulverized coal power plants show that flue gas moisture flow rates range from more than $200,000 \mathrm{lb} / \mathrm{hr}$ for units firing bituminous coals to $600,000 \mathrm{lbs} / \mathrm{hr}$ of water for units firing high moisture lignites. In contrast, for a 585 MW unit, typical flow rates of makeup water to an evaporative cooling tower are 2.1 million lbs/hr. Thus, coal-fired power plants, equipped with the means of extracting all the flue gas moisture and using it for cooling tower makeup water, would be able to supply from approximately 10 percent (for-low moisture bituminous coals) to approximately 18 percent (for Powder River Basin coals) to approximately 29 percent (for high moisture U.S. lignites) of the makeup water by this approach.

Flue gas from coal-fired boilers contains concentrations of sulfuric acid $\left(\mathrm{H}_{2} \mathrm{SO}_{4}\right)$ ranging up to $50 \mathrm{ppm}$ with acid dewpoints in the 230 to $300^{\circ} \mathrm{F}$ range. Stack emissions of $\mathrm{H}_{2} \mathrm{SO}_{4}$ from coal-fired boilers has emerged as a serious problem in recent years, particularly for some boilers equipped with $\mathrm{SCR}$ reactors for $\mathrm{NO}_{\mathrm{x}}$ control. A side benefit of cooling the flue gas to remove $\mathrm{H}_{2} \mathrm{O}$ is simultaneous removal of vapor phase $\mathrm{SO}_{3} / \mathrm{H}_{2} \mathrm{SO}_{4}$ and removal of other acidic compounds such as nitric acid $\left(\mathrm{HNO}_{3}\right)$ and hydrochloric acid $(\mathrm{HCl})$. As will be shown by test results generated in this project, the flue gas vapor phase mercury concentration also decreased between the inlet and exit of the heat exchanger.

There can also be boiler efficiency and heat rate benefits from cooling flue gas to dry it. If the rejected sensible and latent heat could be used beneficially in the boiler or turbine cycle, this would result in a decrease in net unit heat rate. In addition, the reduced stack gas flow rate would result in a lower power requirement for the induced draft fans. Some of these gains would be balanced out by an increase in gas side pressure drop due to the moisture removal equipment.

Different process arrangements will be possible, depending on the application. For power plants with cold side ESP's or baghouses for particulate control, but without wet flue gas $\mathrm{SO}_{2}$ scrubbers (FGD), the heat exchangers would be located between the cold side ESP or baghouse and the stack. For power plants with FGD's, one heat 
exchanger could be located between the ESP and FGD and additional heat exchangers could be located between the FGD and stack (see Figure 1-2).
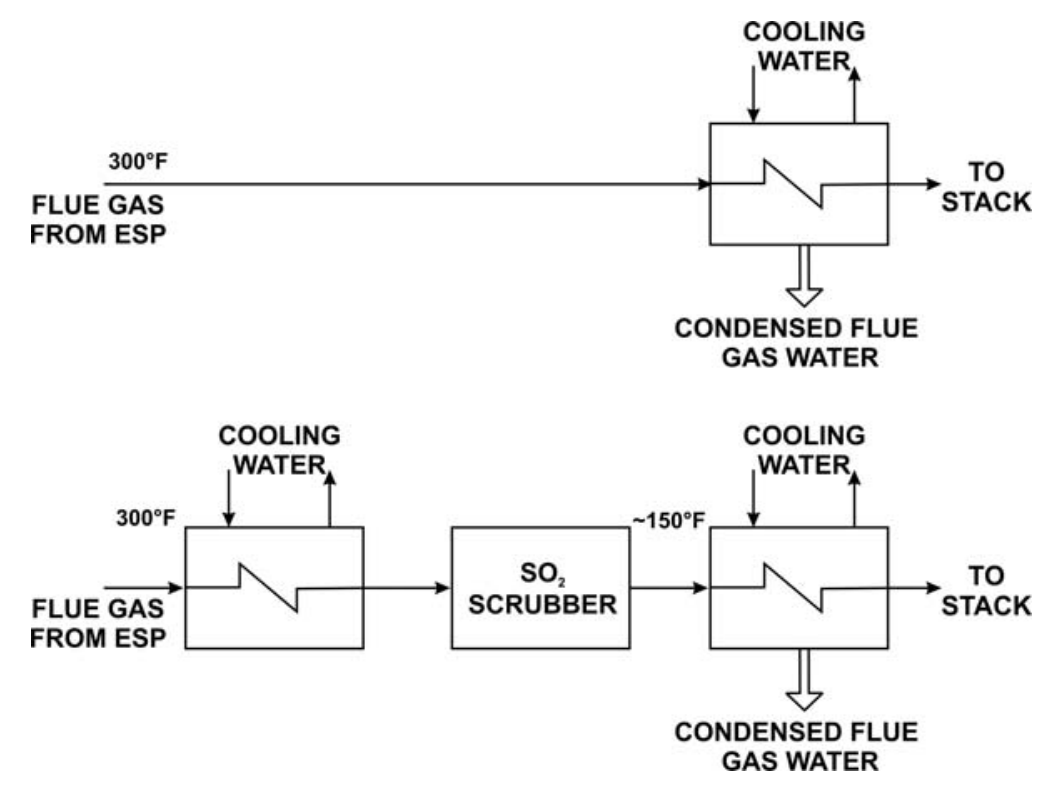

Figure 1-2: Potential Locations of Flue Gas Heat Exchangers for Coal-Fired Units With and Without $\mathrm{SO}_{2}$ Scrubbers.

There are also potential applications of condensing heat exchangers in carbon capture and sequestration systems (CCS). Amine and ammonia $\mathrm{CO}_{2}$ scrubbers require inlet flue gas temperatures of $60^{\circ} \mathrm{F}$ or lower for efficient operation, and the types of heat exchangers described in this report are candidates for use in pretreating boiler flue gas before it flows into a $\mathrm{CO}_{2}$ scrubber. In addition, it is expected that in most cases the concentrated streams of $\mathrm{CO}_{2}$ produced by post-combustion $\mathrm{CO}_{2}$ scrubber systems and by oxyfuel boilers will be compressed to over 2000 psia before being transported by pipeline to geologic sequestration sites. These concentrated streams of $\mathrm{CO}_{2}$ will contain high concentrations of water vapor which should be separated from the $\mathrm{CO}_{2}$ before compression, and here, too, condensing heat exchangers of the type described in this report may have an important role to play (Figure 1-3). 


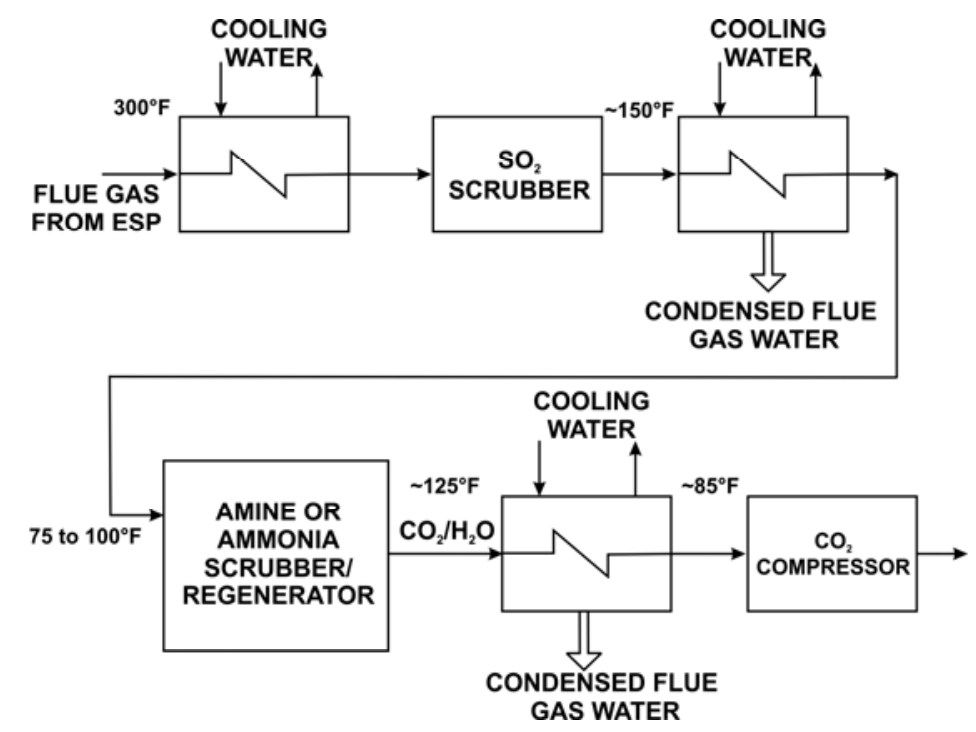

Figure 1-3: Applications of Condensing Heat Exchangers for Pretreating Boiler Flue Gas Prior to Processing by Flue Gas $\mathrm{CO}_{2}$ Scrubbers and for Removing Moisture from Concentrated Streams of $\mathrm{CO}_{2}$ Prior to $\mathrm{CO}_{2}$ Compression.

\section{Objectives and Scope of Project}

The objective of this project was to investigate the use of condensing heat exchangers to recover water vapor from flue gas at coal-fired power plants. Pilot scale heat transfer tests were performed to determine the relationship between flue gas moisture concentration, heat exchanger design and operating conditions, and water vapor condensation rate. The tests also determined the extent to which the condensation processes for water and acid vapors in flue gas can be made to occur separately in different heat transfer sections. Measurements were made of flue gas mercury concentrations upstream and downstream of the heat exchangers to determine if the heat exchangers would reduce flue gas mercury concentration. A theoretical heat and mass transfer model was developed for predicting rates of heat transfer and water vapor condensation and comparisons were made with pilot scale measurements. Analyses were also carried out to estimate how much flue gas moisture it would be possible to recover from boiler flue gas and the magnitude of the heat rate improvements which could be made by recovering sensible and latent heat from flue gas. 


\section{CHAPTER 2}

\section{CONDENSING HEAT EXCHANGER APPARATUS AND PILOT-SCALE TEST SITES}

The condensing heat exchanger apparatus developed and tested in this project consisted of a long rectangular duct containing water-cooled heat exchangers arranged in series (Figures 2-1 and 2-2). Hot flue gas entered the apparatus from the back end of the boiler and as it passed through the heat exchangers, the flue gas was cooled.

Two types of heat exchangers were used to condense water vapor at the low temperature end of the apparatus: heat exchangers with smooth wall tubes (bare tube heat exchangers) (Figure 2-1) and a combination of heat exchangers with smooth wall tubes and a heat exchanger with fins for enhanced heat transfer (Figure 2-2). The bare tube heat exchangers were fabricated from 0.5 inch OD tubing. The total length of tubing in each bare tube heat exchanger ranged up to $133.7 \mathrm{ft}$ with up to a $17.6 \mathrm{ft}^{2}$ surface area (See Figure 2-3).

The fin tube heat exchanger was made from 0.5 inch OD tubing, the total length of tubing used was $46.7 \mathrm{ft}$ and the total surface area was $29.31 \mathrm{ft}^{2}$ (see Table 2-1 for heat exchanger heat transfer surface areas). The spiral (edge wound) fins were 0.25 inch high, 0.015 inch thick and had a pitch of 5 fins per inch (Figure 2-4).

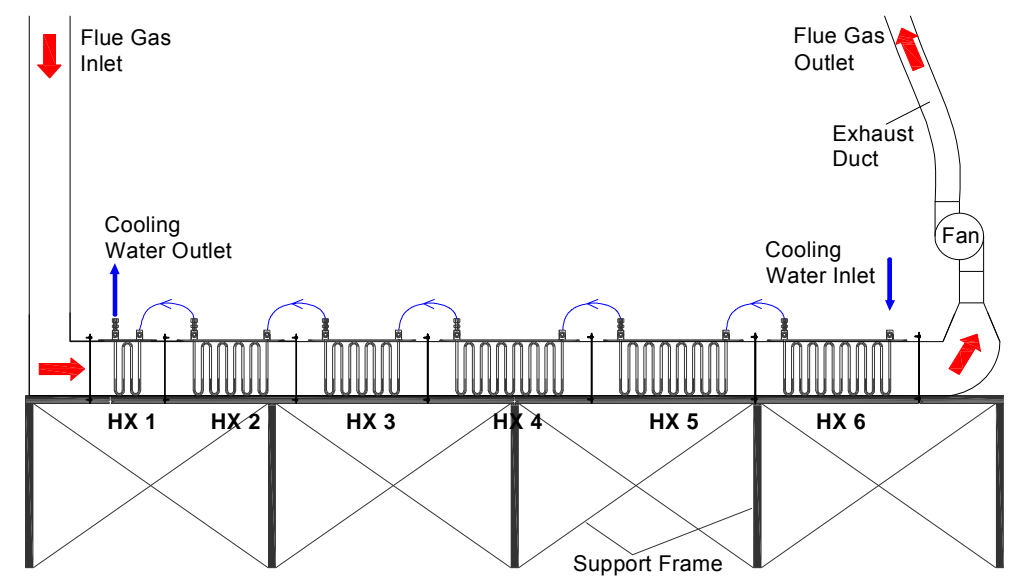

Figure 2-1: Elevation View of Test Apparatus with Three Bare Tube Heat Exchangers (HX4 to HX6) in the Water Vapor Condensation Zone. 


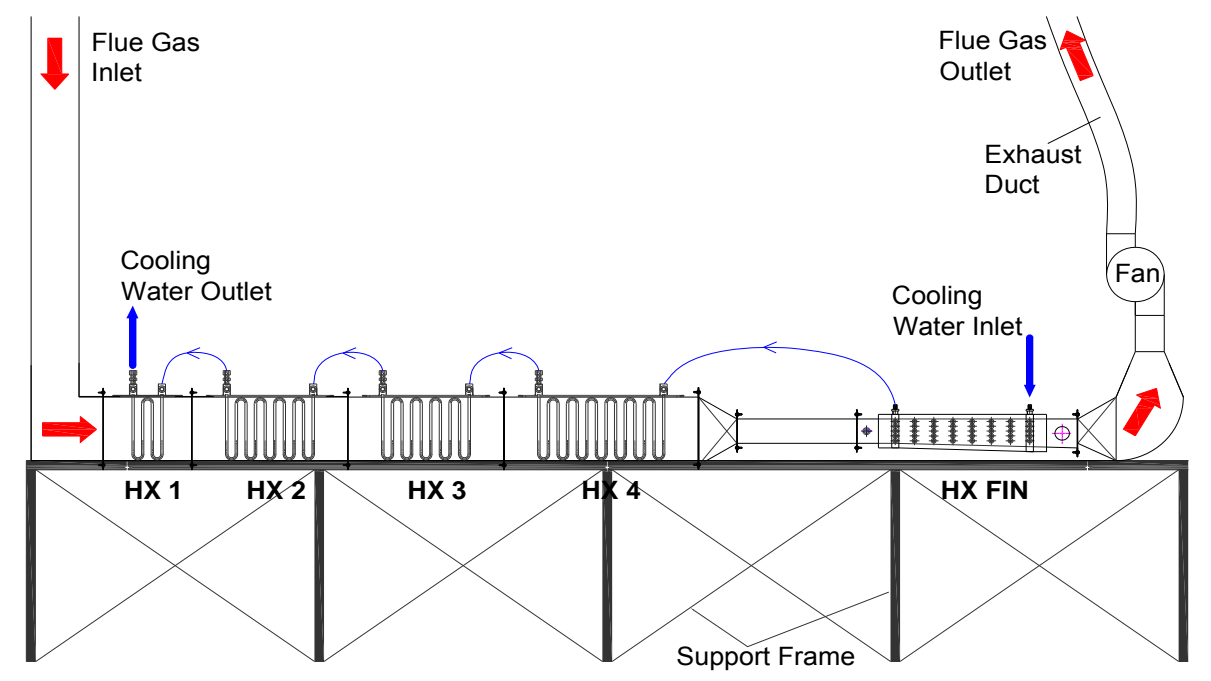

Figure 2-2: Elevation View of Test Apparatus with One Bare Tube Heat Exchanger (HX4) and One Fin Tube Heat Exchanger (HXFIN) in the Water Vapor Condensation Zone.

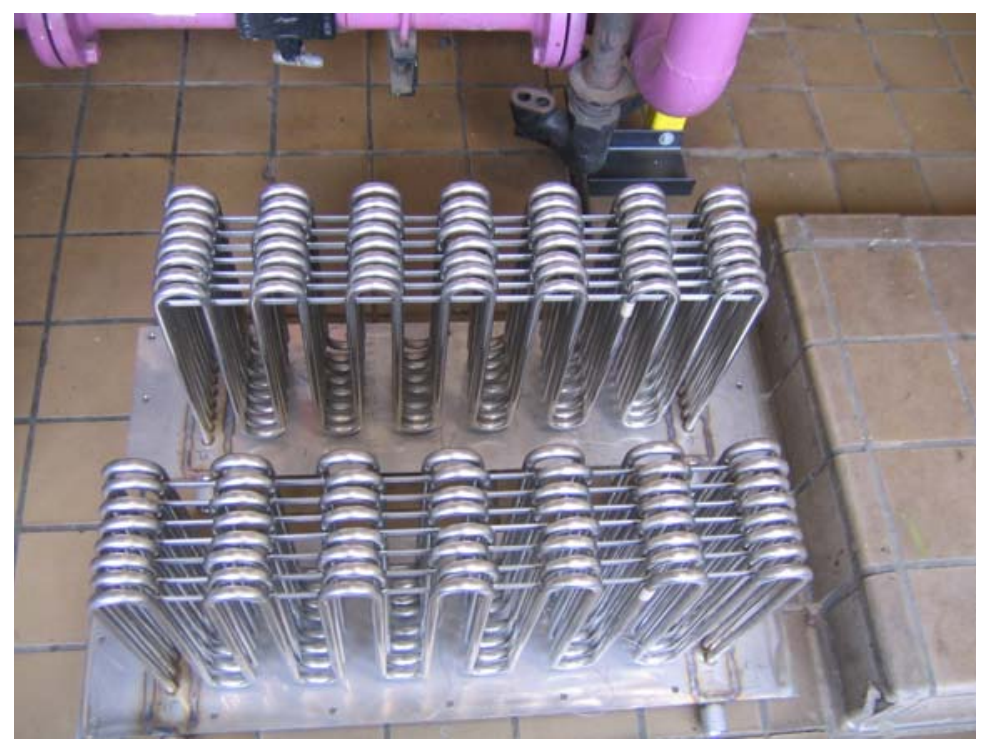

Figure 2-3: Photograph of Two Bare Tube Heat Exchanger Bundles. 
Table 2-1

Heat Transfer Surface Area of Each Heat Exchanger

\begin{tabular}{|c|c|c|c|}
\hline Bare Tube Array & Area $\left(\mathrm{ft}^{2}\right)$ & Combined $\mathrm{Ba}$ & $\begin{array}{l}\text { Tube Array } \\
\text { Area }\left(\mathrm{ft}^{2}\right)\end{array}$ \\
\hline HX1 & 5.05 & HX1 & 5.05 \\
\hline $\mathrm{HX} 2$ & 7.57 & $\mathrm{HX} 2$ & 7.57 \\
\hline $\mathrm{HX} 3$ & 12.59 & HX3 & 12.59 \\
\hline $\mathrm{HX} 4$ & 17.61 & $\mathrm{HX} 4$ & 17.61 \\
\hline $\mathrm{HX5}$ & 17.61 & HXFIN & 29.31 \\
\hline $\mathrm{HX6}$ & 17.61 & & \\
\hline
\end{tabular}

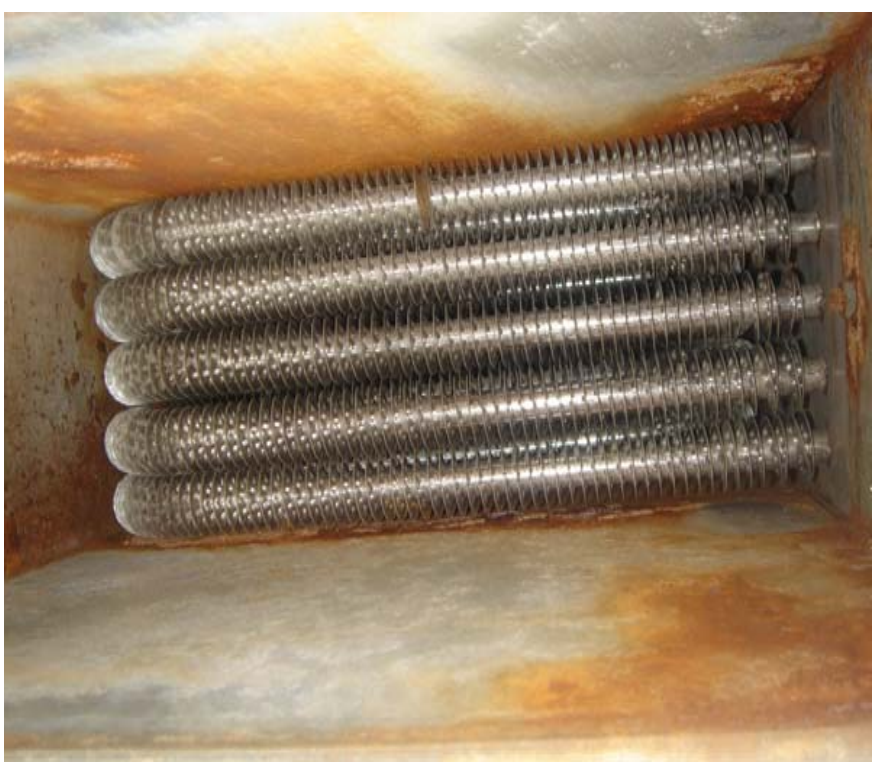

Figure 2-4: Fin-Tube Heat Exchanger Bundle Mounted in Duct.

All the heat exchangers operated in counterflow, with cooling water flowing through the tubes and flue gas flowing outside of the tubes.

The apparatus was instrumented with sensors to measure water and flue gas flow rates; flue gas, cooling water, and tube wall temperatures; and wet bulb and dry bulb temperatures of the flue gas as it exits from the apparatus. Condensed flue gas water vapor drained from the heat exchangers into collection jars, and rates of condensation of water vapor were determined by periodically emptying the collection jars and weighing the condensate. In addition, the Controlled Condensation method (Ref. 2) was used during some tests to determine flue gas $\mathrm{H}_{2} \mathrm{SO}_{4}$ concentrations before and after each of the heat exchangers. 
Pilot scale testing of the condensing heat exchangers was carried out at two boilers: a boiler which fires fuel oil and natural gas and a boiler at a coal-fired power plant. In tests at the oil and gas-fired boiler, a slip stream of flue gas was taken from downstream of the economizer. In tests at the coal-fired power plant, the apparatus was mounted on top of the flue gas duct between the ESP and stack, with hot flue gas which entered the apparatus from the ESP, being cooled as it passed through the heat exchangers. During some tests at the coal-fired boiler, sorbent traps (Method Appendix $\mathrm{K}$ ) were used to measure concentrations of $\mathrm{Hg}$ entering and exiting the heat exchanger assembly (Ref. 3).

The boiler providing flue gas for the experiments at the coal-fired power plant was operating with a high moisture, low sulfur coal (see Table 2-2). The flue gas moisture content ranged from approximately 13 to $15 \%$ (by volume) and $\mathrm{H}_{2} \mathrm{SO}_{4}$ concentrations entering the condensing heat exchanger apparatus were approximately 20 ppm.

Table 2-2

Typical Ultimate Analysis of Coal Used at the Test Site

\begin{tabular}{|c|c|c|}
\hline $\begin{array}{l}\text { Ultimate } \\
\text { Analysis } \\
\end{array}$ & $\%$ Dry Basis & $\begin{array}{c}\% \text { As- } \\
\text { Received } \\
\end{array}$ \\
\hline Carbon & 72.72 & 54.10 \\
\hline Hydrogen & 4.69 & 3.49 \\
\hline Nitrogen & 0.99 & 0.74 \\
\hline Oxygen & 20.3 & 15.10 \\
\hline Sulphur & 0.12 & 0.09 \\
\hline Moisture & 0.00 & 25.60 \\
\hline Ash & 1.21 & 0.90 \\
\hline Total & 100.03 & 100.02 \\
\hline $\mathrm{HHV}$ & & 9,439 \\
\hline
\end{tabular}

At the oil and gas fired boiler, the flue gas water vapor concentrations at the inlet to the heat exchanger apparatus were 11 to 13 vol\% during operation with oil and 13 to $17 \%$ during operation with natural gas. 


\section{CHAPTER 3}

\section{MEASUREMENTS OF WATER VAPOR CAPTURE RATES}

\section{Bare Tube Heat Exchangers}

Figures 3-1 to 3-3 show the flue gas moisture fractions (volume \%) and flue gas and cooling water temperatures during tests at the coal-fired power plant with inlet cooling water temperatures from 77 to $100^{\circ} \mathrm{F}$. These data were obtained with bare tube heat transfer bundles installed in the low temperature region of the heat exchange system (Figure 2-1). At the time these measurements were made, the unit was burning a high moisture coal, resulting in flue gas inlet moisture fractions of approximately 13.5 vol \%. The flue gas entered at $300^{\circ} \mathrm{F}$ and exited at temperatures ranging from approximately 85 to $110^{\circ} \mathrm{F}$. The total moisture capture efficiency, defined as

Capture Efficiency = (rate of water capture) / (water vapor flow rate in inlet flue gas)

is shown in Figure 3-4 as a function of inlet cooling water temperature, and this shows capture efficiencies from 48 to 75 wt percent over the range of inlet cooling water temperatures from $77 \mathrm{~F}$ to $100^{\circ} \mathrm{F}$. Figure $3-5$ shows how capture efficiency depended on inlet cooling water flow rate, increasing from 60 wt percent at $750 \mathrm{lb} / \mathrm{hr}$ to 68 percent at $1450 \mathrm{lb} / \mathrm{hr}$.

Figure 3-6 shows data on total water capture efficiency obtained at the oil fired boiler with inlet water temperatures from 41 to $75^{\circ} \mathrm{F}$ and with inlet cooling water and flue gas flow rates in the same range as those shown in Figures 3-4 and 3-5 for flue gas obtained while firing coal. The inlet flue gas water vapor concentration obtained while firing fuel oil ranged from 10.4 to $15.4 \mathrm{vol} \%$, with this wide variation possibly occurring due to changes in boiler fuel-to-air ratios. Figure 3-7 shows the variation of water capture efficiency as a function of inlet flue gas flow rate for this same set of data. 


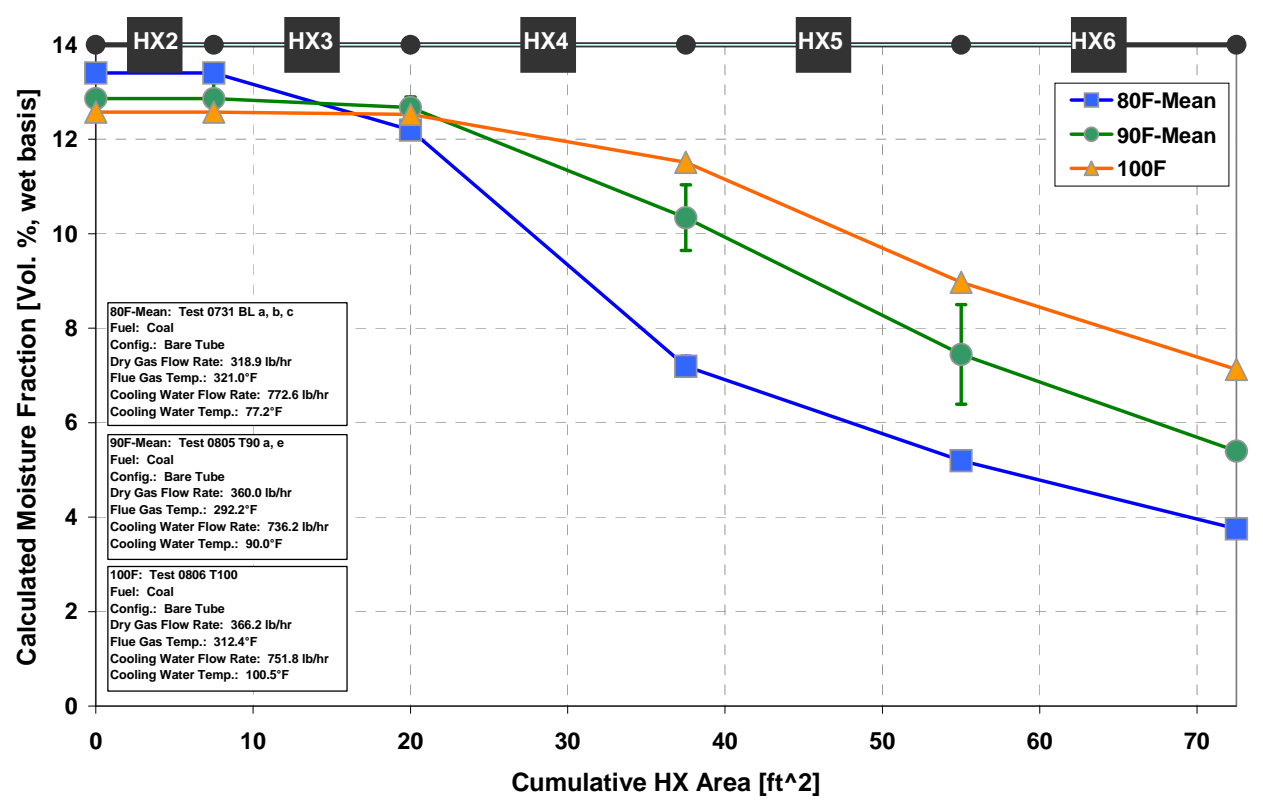

Figure 3-1: Axial Variation of Flue Gas Water Vapor Concentration: Coal Tests. Flue Gas Flows from Left to Right in Graph.

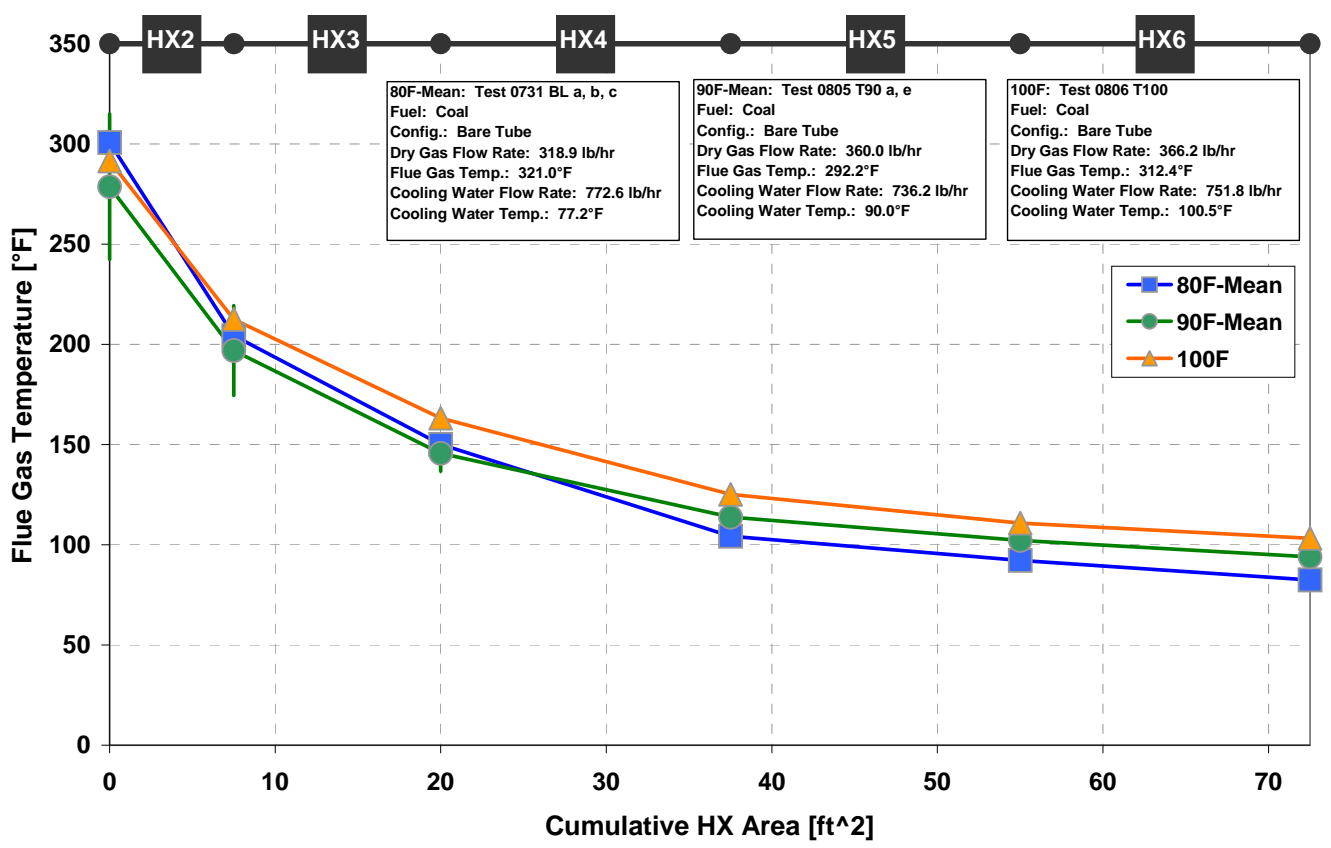

Figure 3-2: Axial Variations of Flue Gas Temperature: Coal Tests. Flue Gas Flows from Left to Right in Graph. 


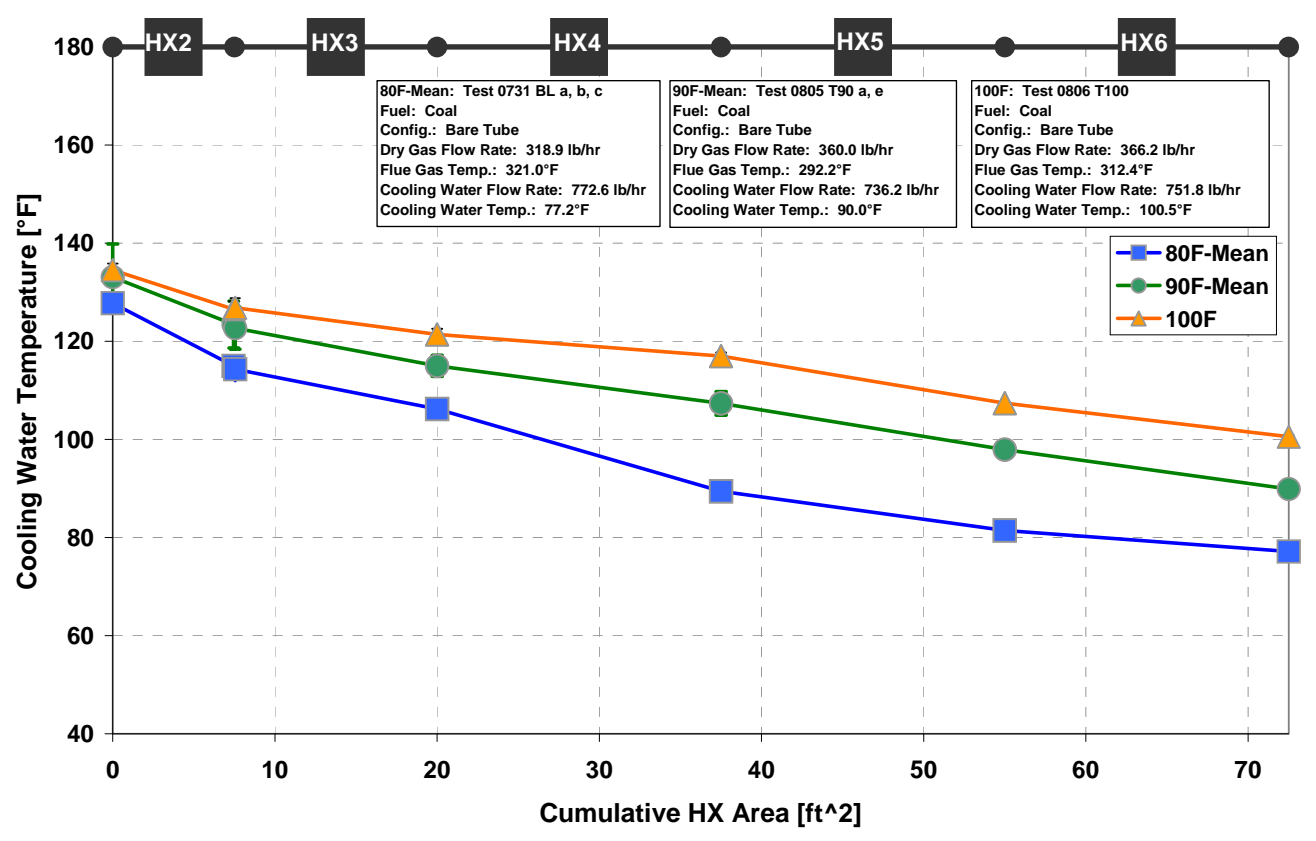

Figure 3-3: Axial Variations of Cooling Water Temperature: Coal Tests. Cooling Water Flows from Right to Left in Graph.

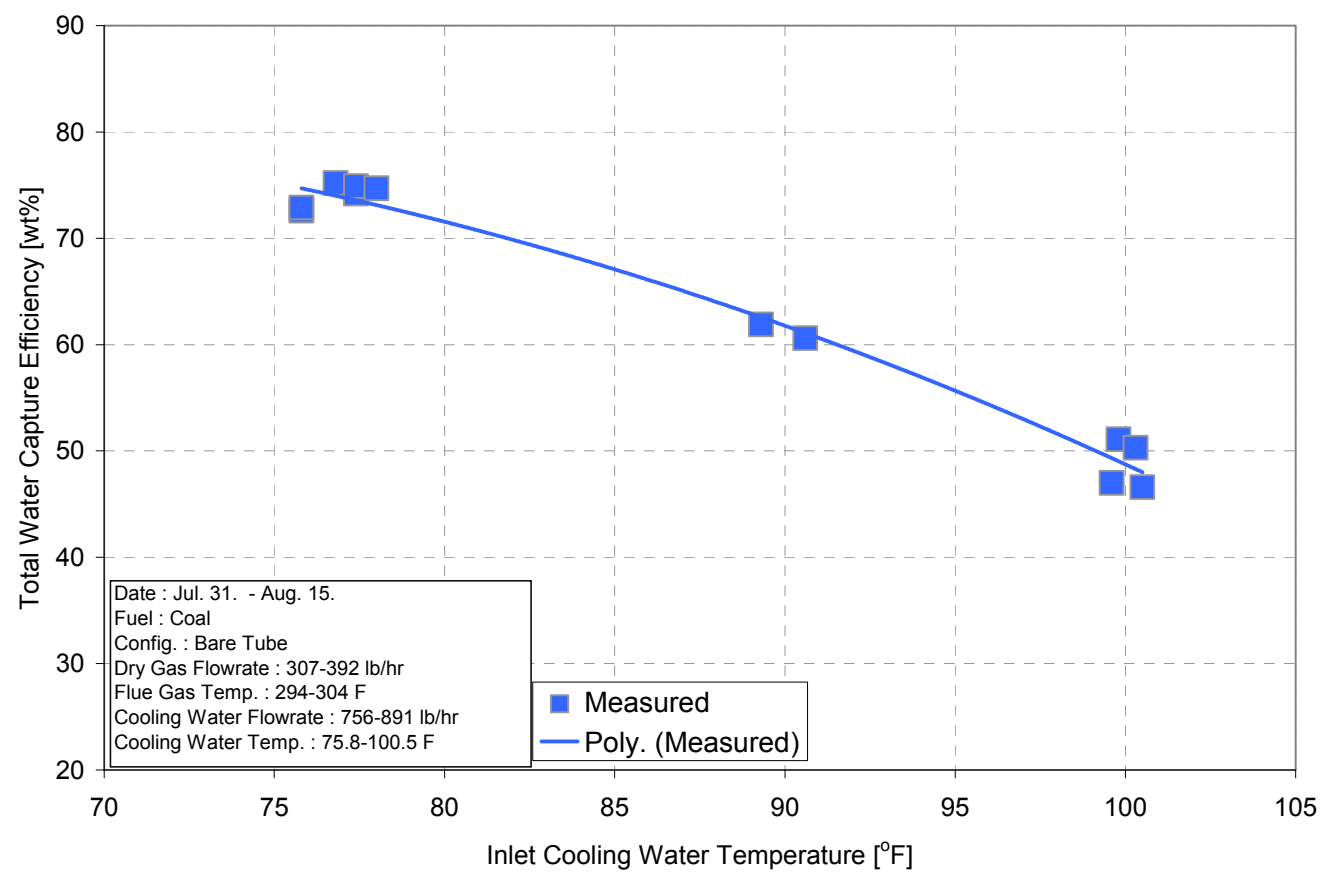

Figure 3-4: Water Vapor Capture Efficiency vs. Inlet Cooling Water Temperature: Coal Tests. 


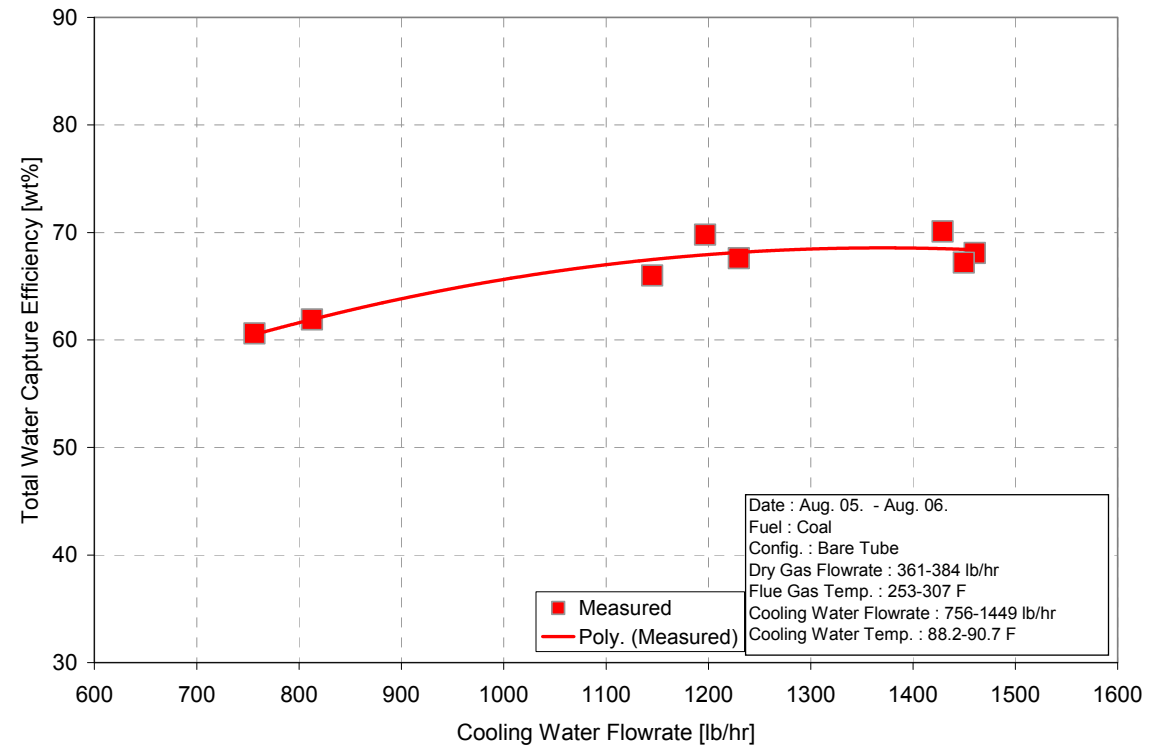

Figure 3-5: Water Capture Efficiency vs. Cooling Water Flow Rate: Coal Tests.

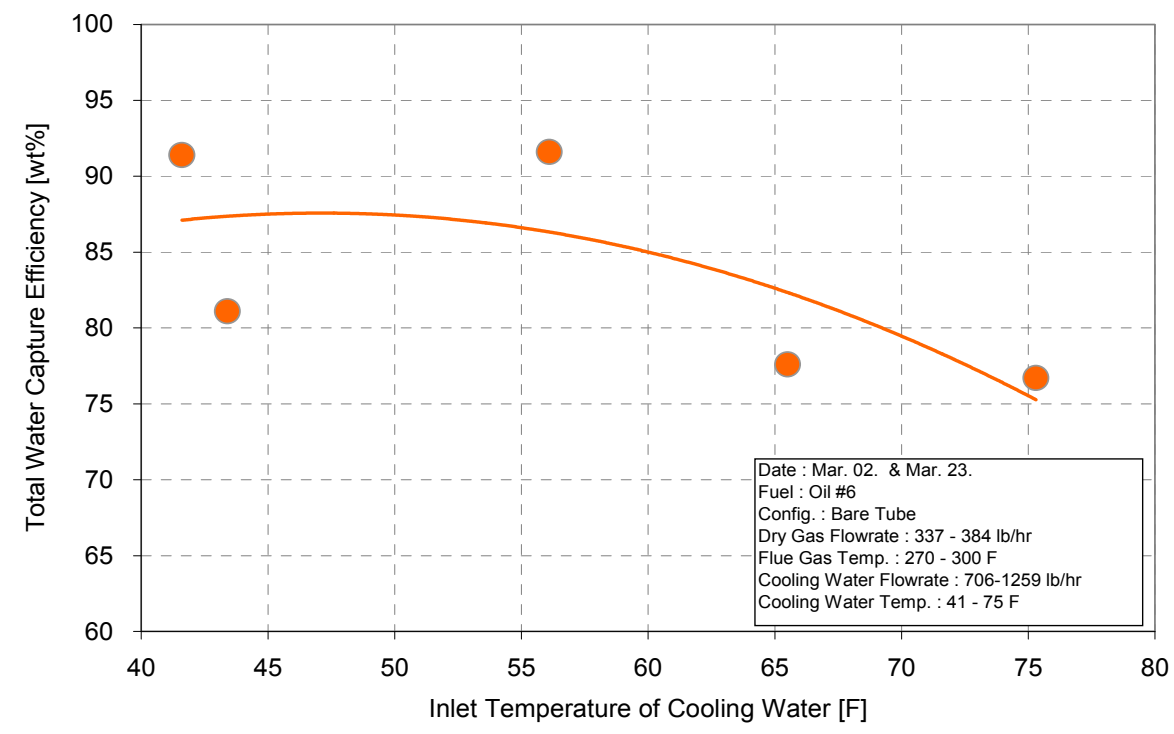

Figure 3-6: Variation of Total Water Capture Efficiency with Inlet Cooling Water Temperature: Tests at Oil-Fired Boiler. 


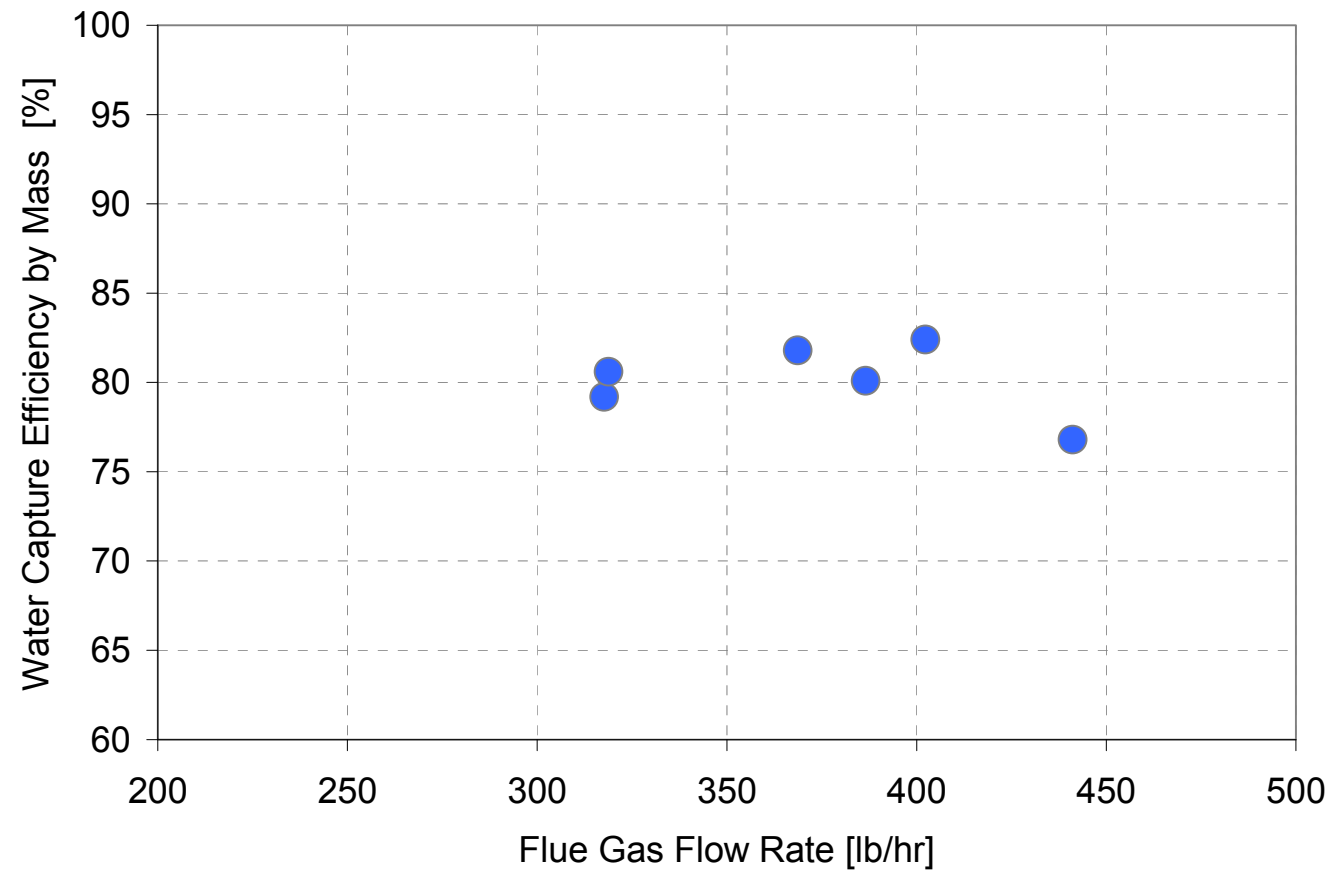

Figure 3-7: Total Water Capture Efficiency vs. Flue Gas Flow Rate: Tests at Oil-Fired Boiler.

\section{Tests with Combination of Bare Tube and Fin Tube Heat Exchangers}

Tests were performed with the combination of a bare tube heat exchanger ( $\mathrm{HX} 4)$ and the fin-tube heat exchanger (HXFIN) in the low temperature end of the heat transfer system (see Figure 2-2). These tests, performed at the coal-fired power plant, were run at three inlet cooling water temperatures, $\left(74^{\circ} \mathrm{F}, 90^{\circ} \mathrm{F}\right.$ and $\left.100^{\circ} \mathrm{F}\right)$, with replicate runs being made at $90^{\circ}$ and $100^{\circ} \mathrm{F}$. Table 3-1 summarizes the test conditions for this test series. The inlet $\mathrm{H}_{2} \mathrm{O}$ volume fraction averaged $14 \%$ for these tests and the inlet flue gas temperature ranged from $292^{\circ} \mathrm{F}$ to $314^{\circ} \mathrm{F}$. Flue gas and cooling water flow rates are shown in Table 3-1. 
Table 3-1

Process Conditions for Fin Tube Tests with Variable Cooling Water Temperature: Coal-Fired Boiler

\begin{tabular}{|c|c|c|c|c|c|}
\hline $\begin{array}{c}\text { Flue Gas Flow } \\
\text { Rate (Corrected) } \\
\mathrm{m}_{\mathrm{fg}, \text { dry gas }} \\
\mathrm{lb} / \mathrm{hr} \\
\end{array}$ & $\begin{array}{c}\text { Water Vapor } \\
@ \text { Inlet } \\
\text { m }_{w v} \\
\text { lb/hr }\end{array}$ & $\begin{array}{c}\text { Flue Gas Temp. } \\
\text { @ Inlet } \\
\mathrm{T}_{\mathrm{fg}} \\
{ }^{\circ} \mathrm{F} \\
\end{array}$ & $\begin{array}{c}\text { Moisture } \\
\text { Fraction @ Inlet } \\
\text { Ун2O, wet Basis } \\
\text { Vol. \% } \\
\end{array}$ & $\begin{array}{c}\text { Cooling Water } \\
\text { Flow Rate } \\
\text { m }_{\mathrm{cw}} \mathrm{lb} / \mathrm{hr}\end{array}$ & $\begin{array}{c}\text { Cooling Water } \\
\text { Temp. @ Inlet } \\
\mathrm{T}_{\mathrm{cw}} \\
{ }^{\circ} \mathrm{F} \\
\end{array}$ \\
\hline 361.0 & 32.8 & 291.5 & 13.3 & 730.0 & 73.4 \\
\hline 321.1 & 30.6 & 296.6 & 13.9 & 737.1 & 73.1 \\
\hline 271.7 & 29.5 & 301.0 & 15.5 & 759.9 & 74.1 \\
\hline 273.4 & 28.6 & 307.2 & 15.0 & 781.9 & 73.2 \\
\hline 285.8 & 26.3 & 312.5 & 13.5 & $\begin{array}{l}781.8 \\
\end{array}$ & 73.1 \\
\hline 302.7 & 27.9 & 313.9 & 13.5 & 781.8 & 75.0 \\
\hline 319.1 & 32.2 & 309.7 & 14.6 & 784.8 & 74.3 \\
\hline 310.7 & 31.0 & 305.6 & 14.4 & 778.9 & 100.6 \\
\hline 310.5 & 29.4 & 304.3 & 13.8 & 778.9 & 99.8 \\
\hline 318.9 & 31.5 & 306.3 & 14.3 & 773.6 & 100.2 \\
\hline 311.5 & 31.0 & 307.1 & 14.4 & 781.9 & 74.1 \\
\hline 316.4 & 31.6 & 312.8 & 14.4 & 1363.1 & 89.8 \\
\hline 318.0 & 30.3 & 296.7 & 13.9 & 1342.1 & 89.7 \\
\hline 280.3 & 27.5 & 292.9 & 14.2 & & 89.4 \\
\hline
\end{tabular}

Figures 3-8 to 3-10 give flue gas $\mathrm{H}_{2} \mathrm{O}$ volume fractions and flue gas and cooling water temperatures as functions of cumulative heat exchanger surface area, and Figure 3-11 shows the total water capture efficiencies for the three inlet cooling water temperatures.

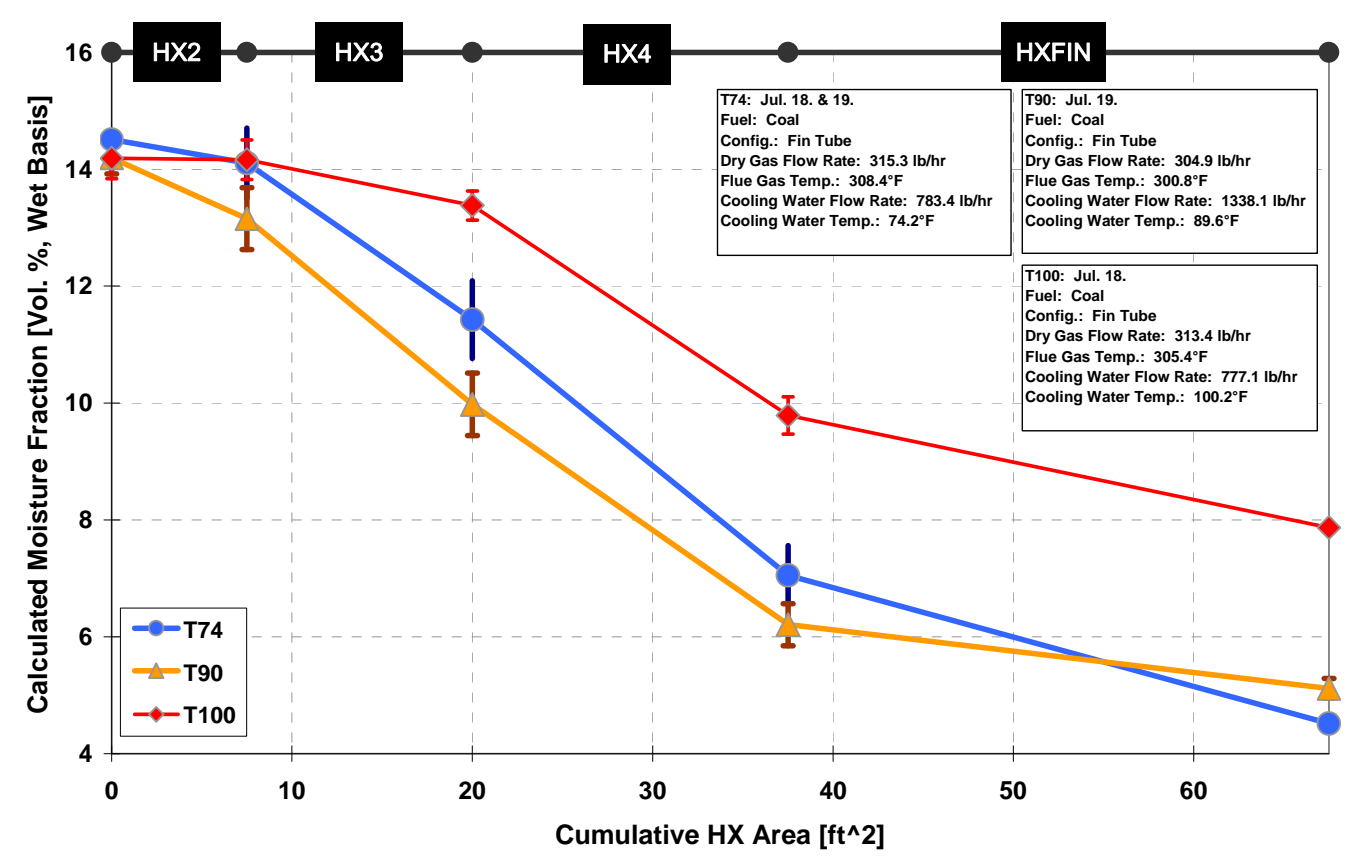

Figure 3-8: Effect of Inlet Cooling Water Temperature on Distribution of Water Vapor Mole Fraction through Combined Bare Tube-Fin Tube Heat Exchanger Array. 


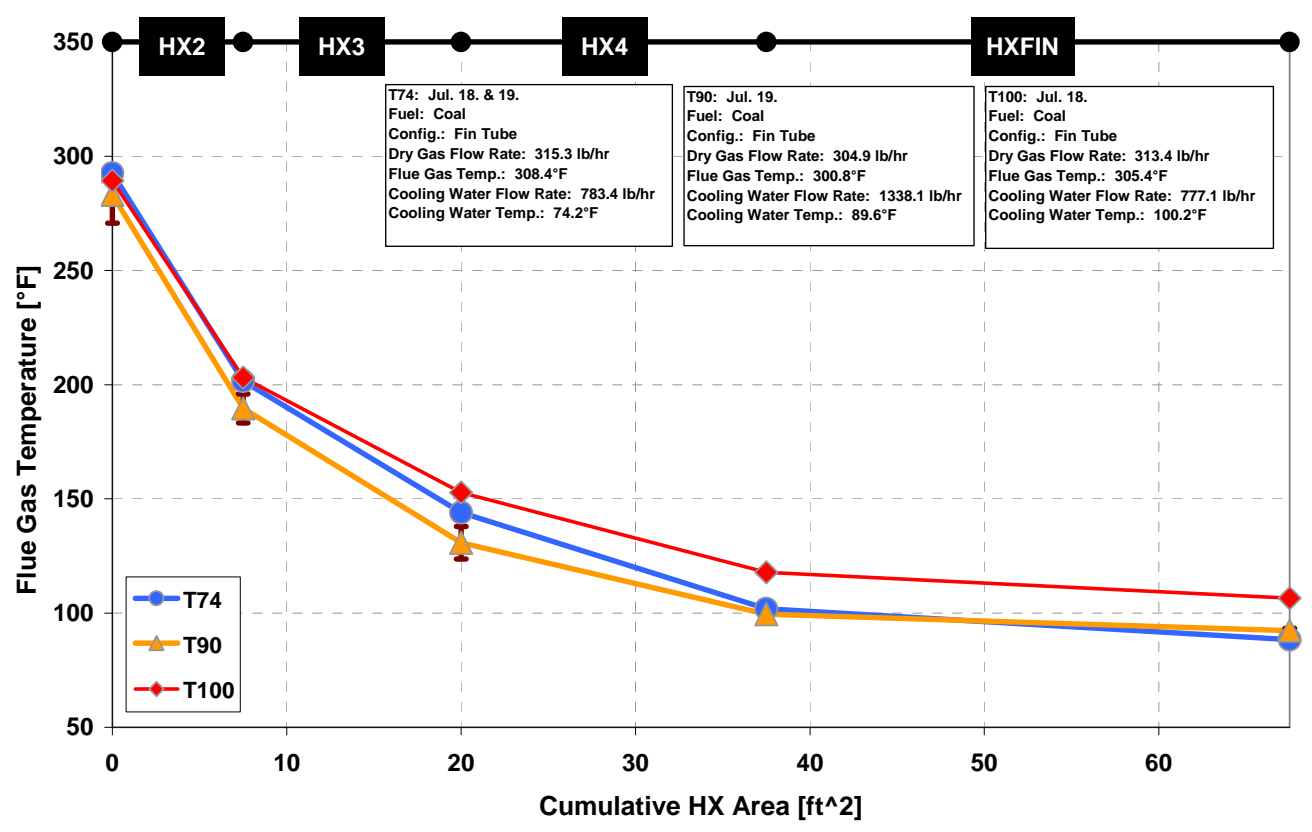

Figure 3-9: Effect of Inlet Cooling Water Temperature on Distribution of Flue Gas Temperature through Combined Bare Tube-Fin Tube Heat Exchanger Array.

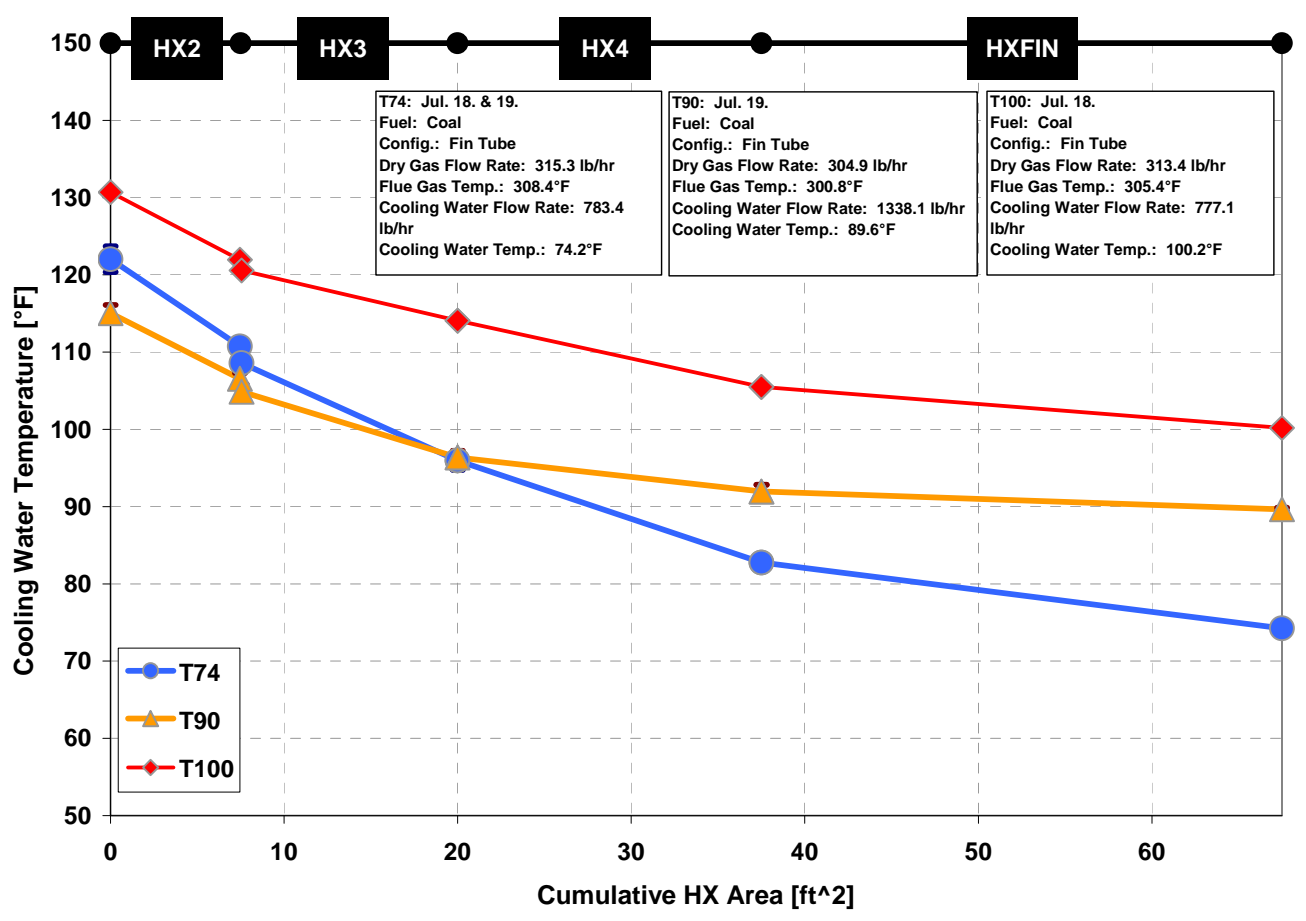

Figure 3-10: Effect of Inlet Cooling Water Temperature on Distribution of Cooling Water Temperature Through Combined Bare Tube-Fin Tube Heat Exchanger Array. 


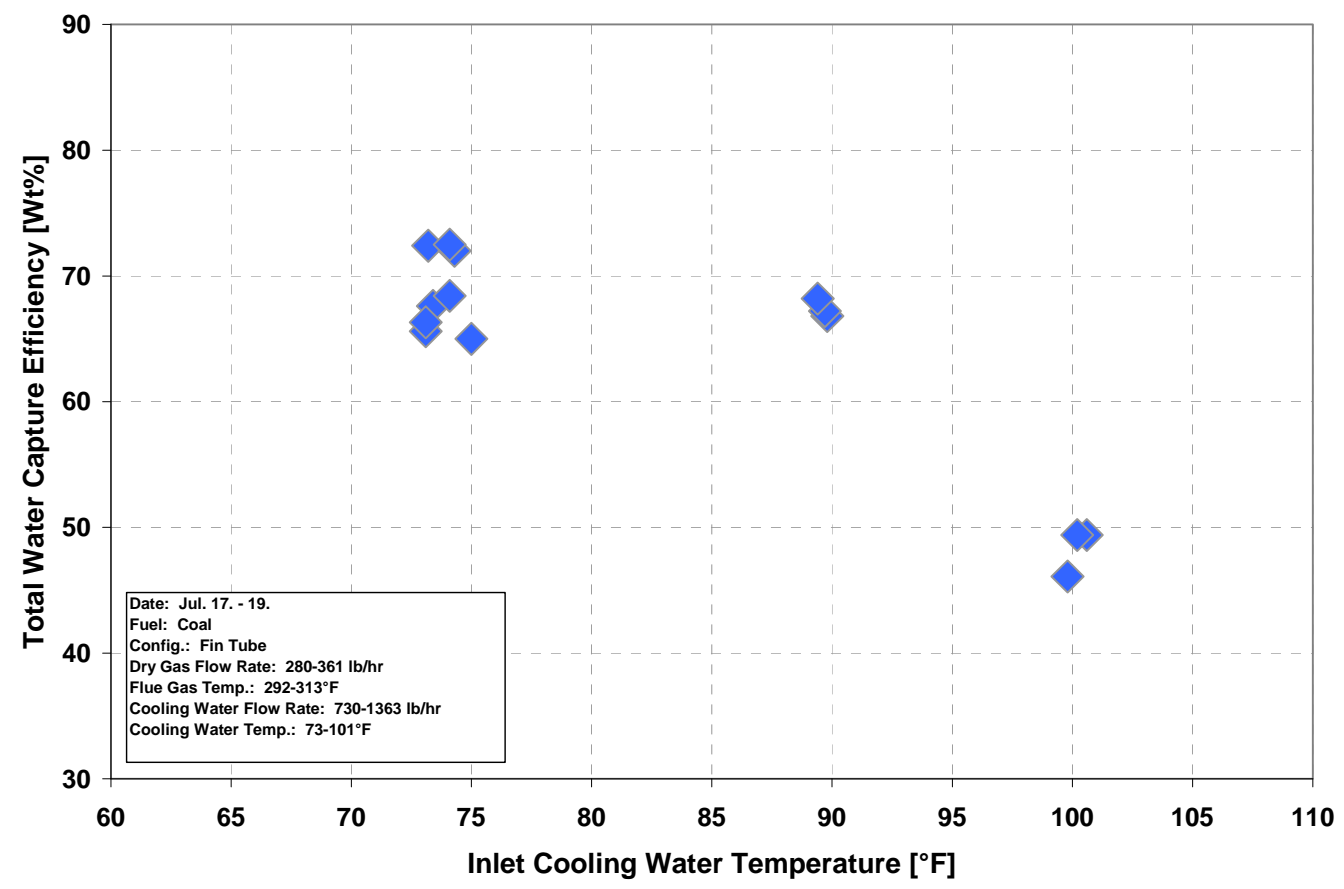

Figure 3-11: Effect of Inlet Cooling Water Temperature on Total Water Vapor Capture Efficiency in Combined Bare Tube-Fin Tube Heat Exchanger Array.

Similar to those with the bare tube heat exchangers (Figure 3-4), these results show a strong effect of cooling water inlet temperature, with overall water capture efficiency ranging from 48 to $70 \mathrm{wt} \%$.

Tests were also run with flue gas flow rates ranging from 302 to $394 \mathrm{lb} / \mathrm{hr}$, with relatively constant values of cooling water inlet temperature and flow rate and flue gas inlet temperature. The overall water vapor capture efficiency was found to be insensitive to flue gas flow rate (Figure 3-12). During these tests, the flue gas inlet moisture volume fraction varied from 13.2 to $15.5 \%$ (Figure 3-13), but these changes in inlet moisture were random, due most likely to changes in coal moisture content. Finally, Figure 3-14 shows the effect of inlet moisture fracture on total moisture capture efficiency for an inlet water temperature of $74^{\circ} \mathrm{F}$. An increase in inlet moisture fraction from 13.2 to 15.5 percent resulted in an increase in capture efficiency from approximately 67 to 72 percent. 


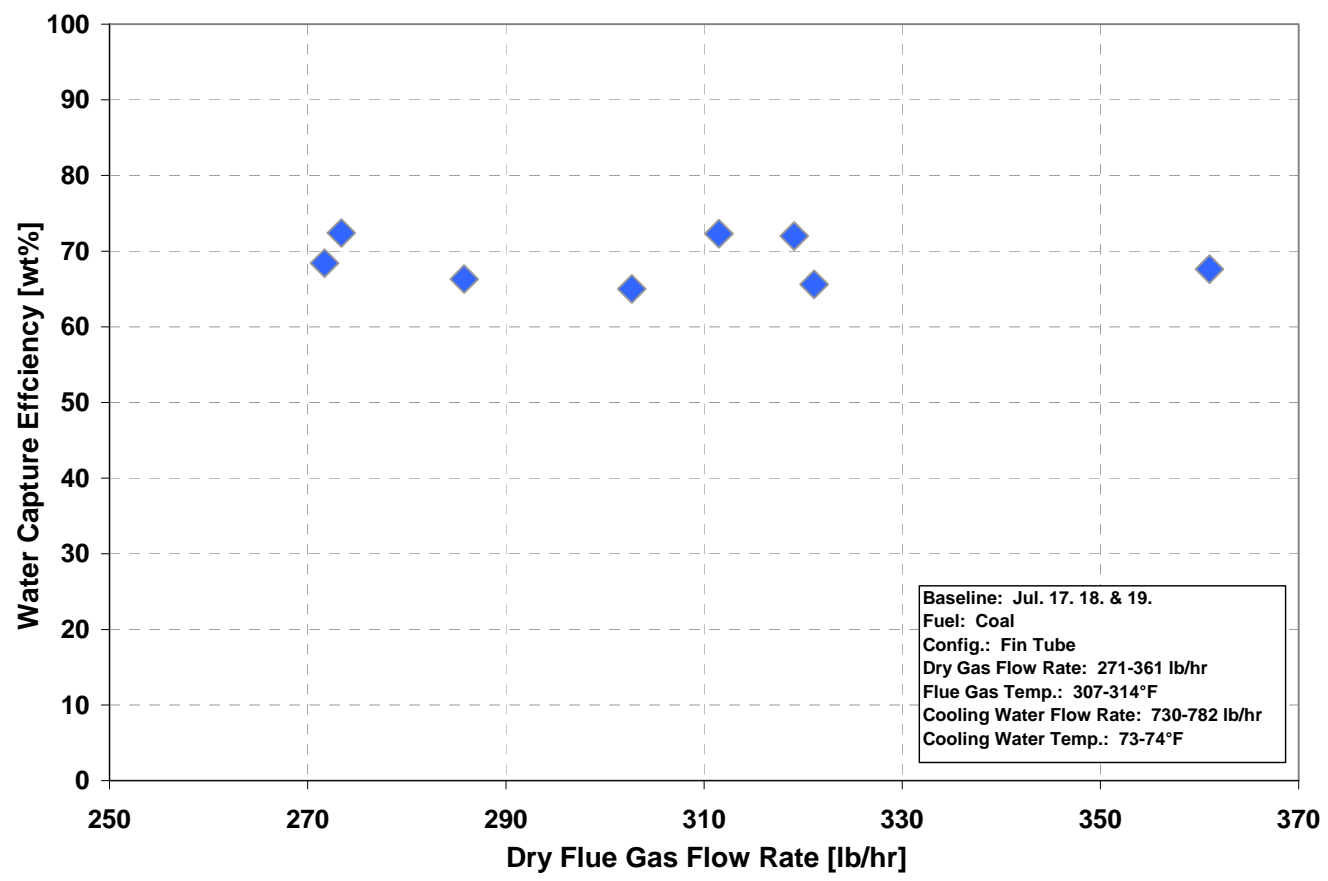

Figure 3-12: Effect of Dry Flue Gas Flow Rate on Total Water Vapor Capture Efficiency in Combined Bare Tube-Fin Tube Heat Exchanger Array.

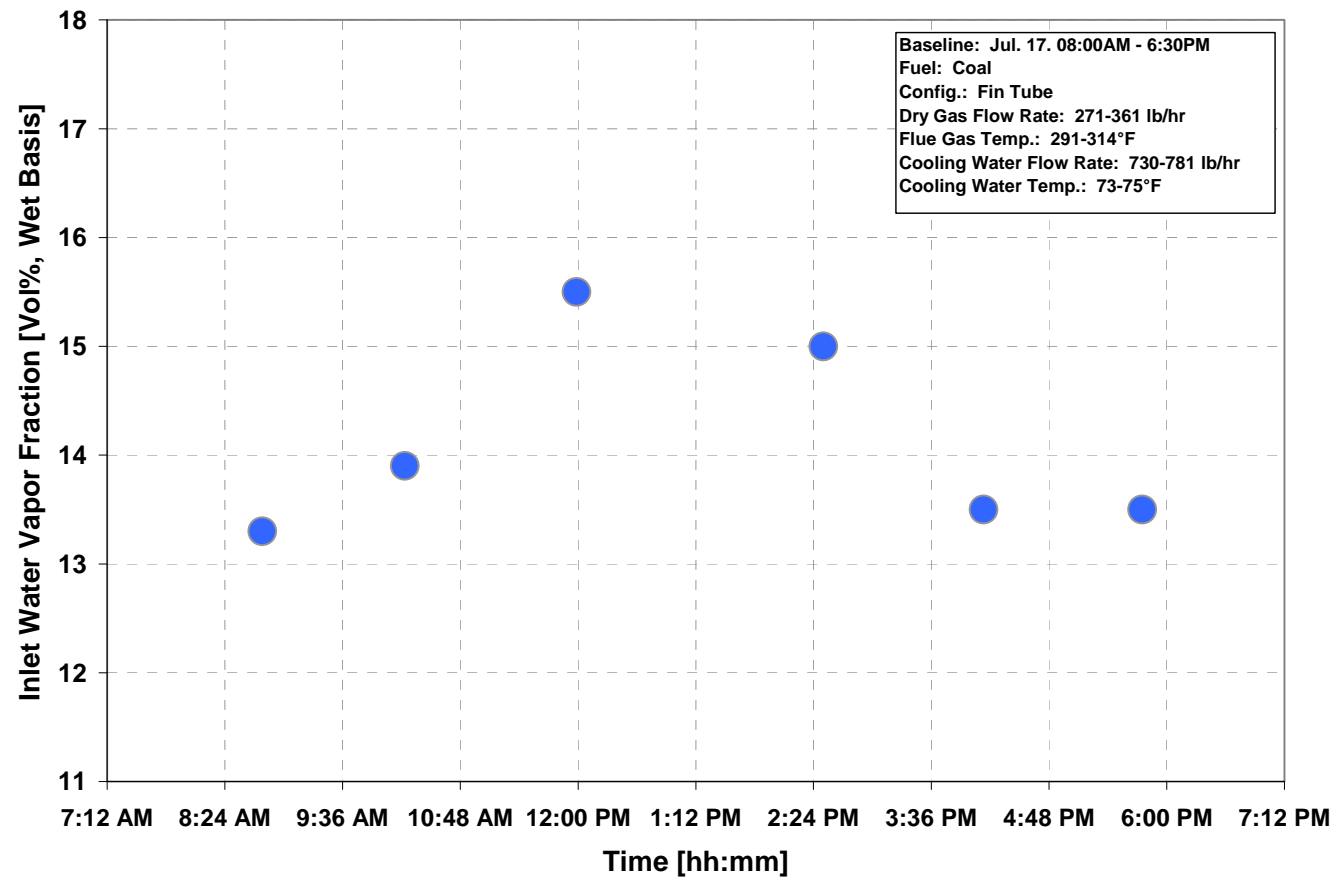

Figure 3-13: Temporal Variation of Inlet Flue Gas Water Vapor Volume Fraction During Tests Over Range of Flue Gas Flow Rates. 


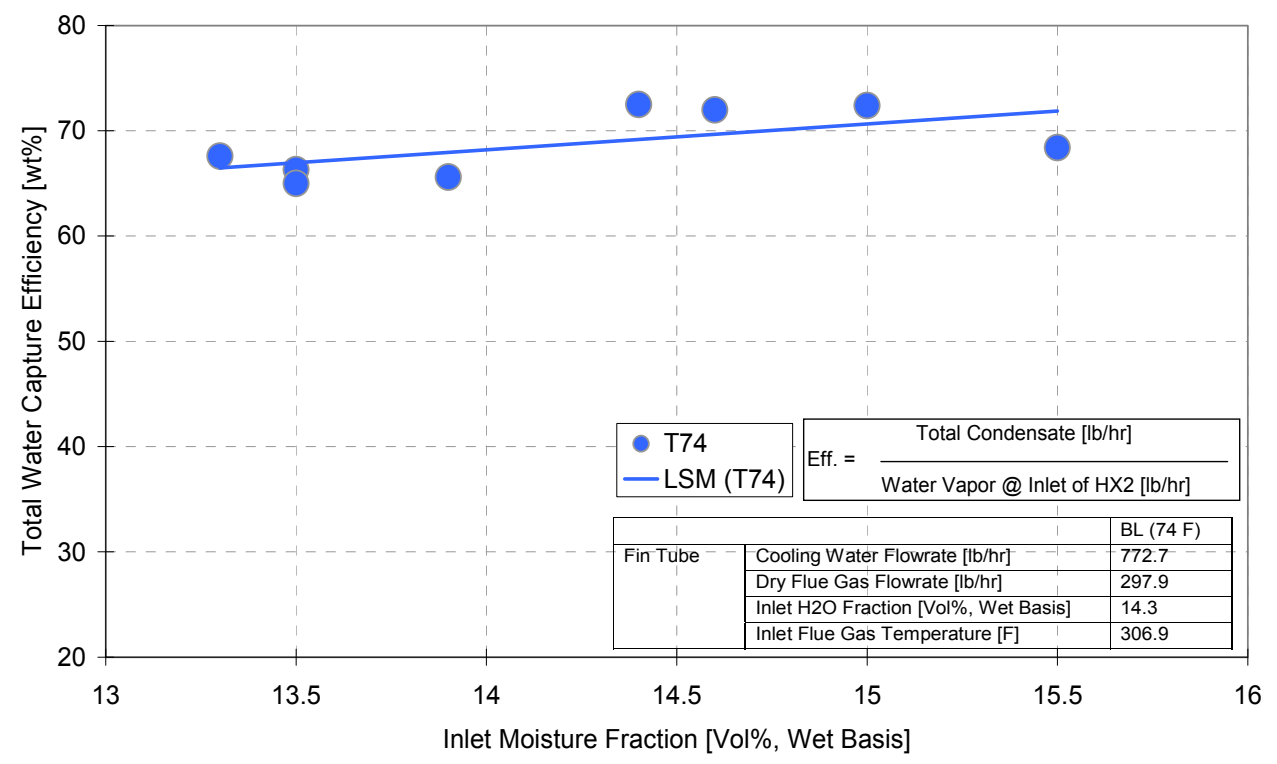

Figure 3-14: Effect of Inlet Moisture Fraction on Total Water Capture Efficiency. Fin-Tube Array with $74^{\circ} \mathrm{F}$ Inlet Water Temperature.

\section{Comparison of Bare Tube and Fin Tube Heat Exchanger Performance}

Comparisons of heat transfer and water vapor condensation performance data were made between the bare tube and combined-bare tube and fin tube heat exchanger arrangements. These data were collected at both the oil-fired and coal-fired boilers. Since the fin tube heat exchanger has a larger surface area than the bare tube bundle (HX6), it is expected that the rate of heat transfer through the fin tube heat exchanger, Q(HXFIN), would be larger than the heat transfer through HX6 for comparable temperature differences and flue gas and cooling water flow rates. The data in Figure 3-15 show that this is indeed the case for three of the four temperatures. The inconsistency in the results for $90^{\circ} \mathrm{F}$ is most likely due to measurement errors. These data are also shown in Table 3-2 as $Q(H X F I N) / Q(H X 5)$ and $Q(H X F I N) / Q(H X 6)$. Treating $\mathrm{Q}(\mathrm{HXFIN}) / \mathrm{Q}(\mathrm{HX} 6)$ at $90^{\circ} \mathrm{F}$ as an outlier, the remaining seven heat flux ratios average 1.67. As might be expected, this average heat flux ratio is nearly identical to the fin tube-to-bare tube heat transfer surface area ratio. 


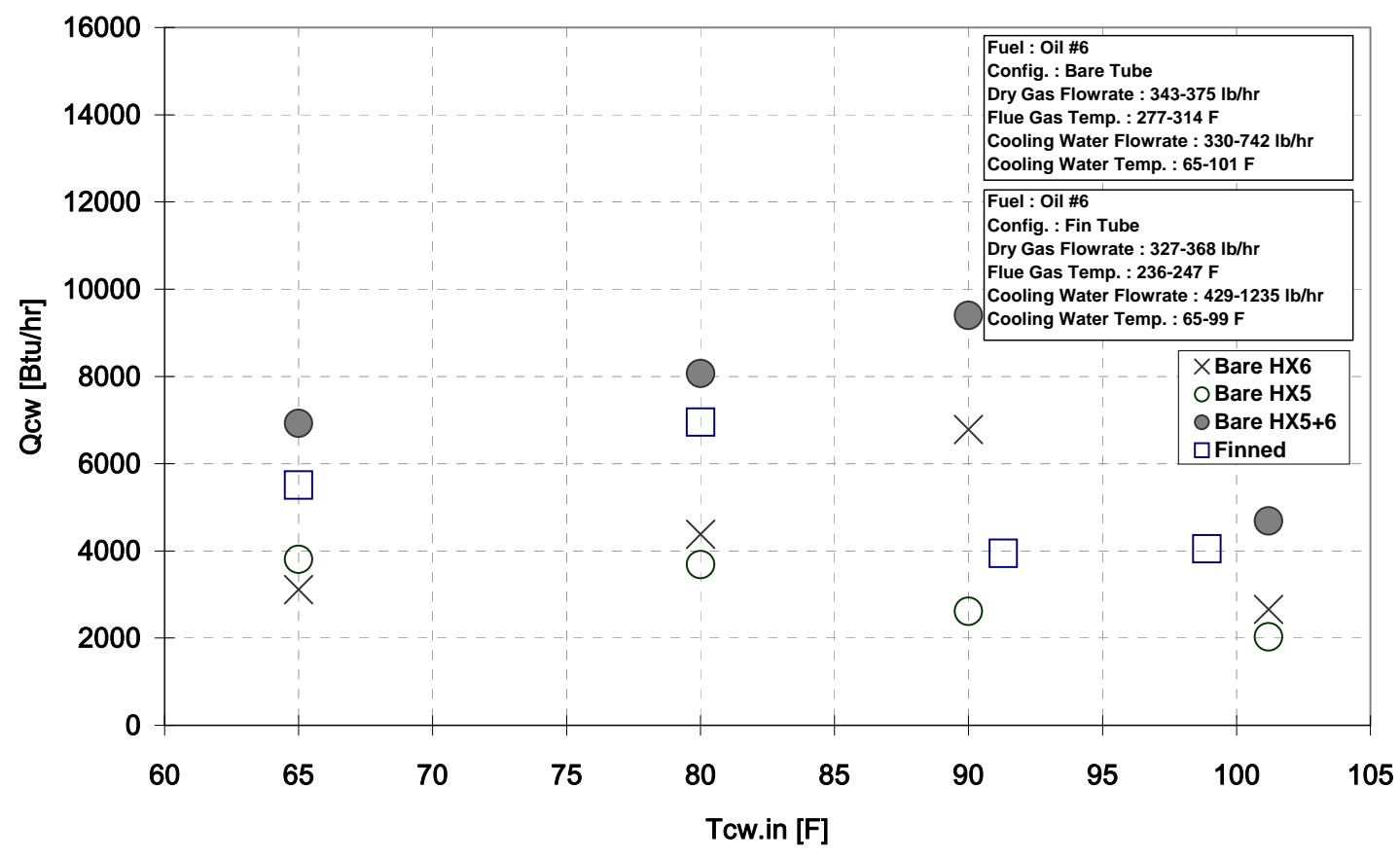

Figure 3-15: Variation of Heat Transfer to Cooling Water with Inlet Cooling Water Temperature. Comparison between Bare Tube and Fin Tube Heat Transfer Bundles.

Table 3-2

Comparison of Rates of Heat Transfer to

Cooling Water with Fin Tube and Bare Tube Heat Exchangers

\begin{tabular}{|c|c|c|c|c|c|}
\hline \multicolumn{5}{|c|}{ Ratios of Q(HXFIN)/Q(HX6) and Q(HXFIN)/Q(HX5) from \#6 Oil Tests } \\
\hline $\mathbf{T}_{\mathrm{cw} \text { in }}\left({ }^{\circ} \mathrm{F}\right)$ & $\mathbf{Q}(\mathbf{H X 6 )}$ & $\mathbf{Q}$ (HX5) & $\mathbf{Q}$ (HXFIN) & $\mathbf{Q}_{\mathrm{FiN}} / \mathbf{Q}(\mathbf{H X 6 )}$ & $\mathbf{Q}_{\mathrm{FiN}} / \mathbf{Q}(\mathbf{H X 5 )}$ \\
\hline 100 & 2660 & 2031 & 4047 & 1.52 & 1.99 \\
\hline 90 & 6784 & 2612 & 3943 & 0.58 & 1.51 \\
\hline 80 & 4383 & 3687 & 6954 & 1.59 & 1.89 \\
\hline 65 & 3114 & 3809 & 5511 & 1.77 & 1.45 \\
\hline
\end{tabular}

Similar comparisons were also made using data from the coal-fired boiler, where the test data used represented the range of inlet water temperatures. The results (Figures 3-16 and 3-17) also show a consistent trend of higher rates of heat transfer and condensation with the fin tube heat exchanger (HXFIN) than was obtained with the bare tube bundle (HX6). 


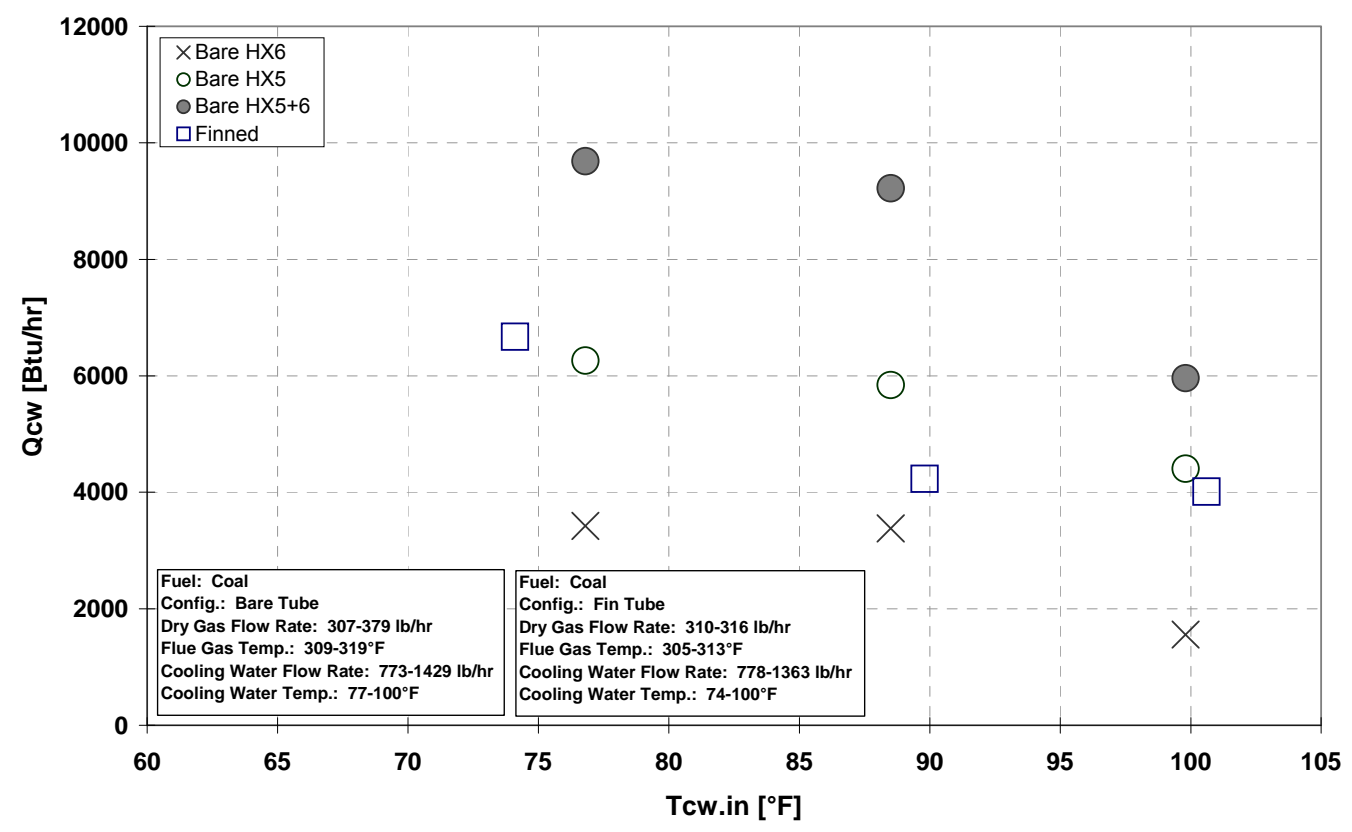

Figure 3-16: Comparison of Rates of Heat Transfer to Cooling Water in HXFin, HX6 and HX5.

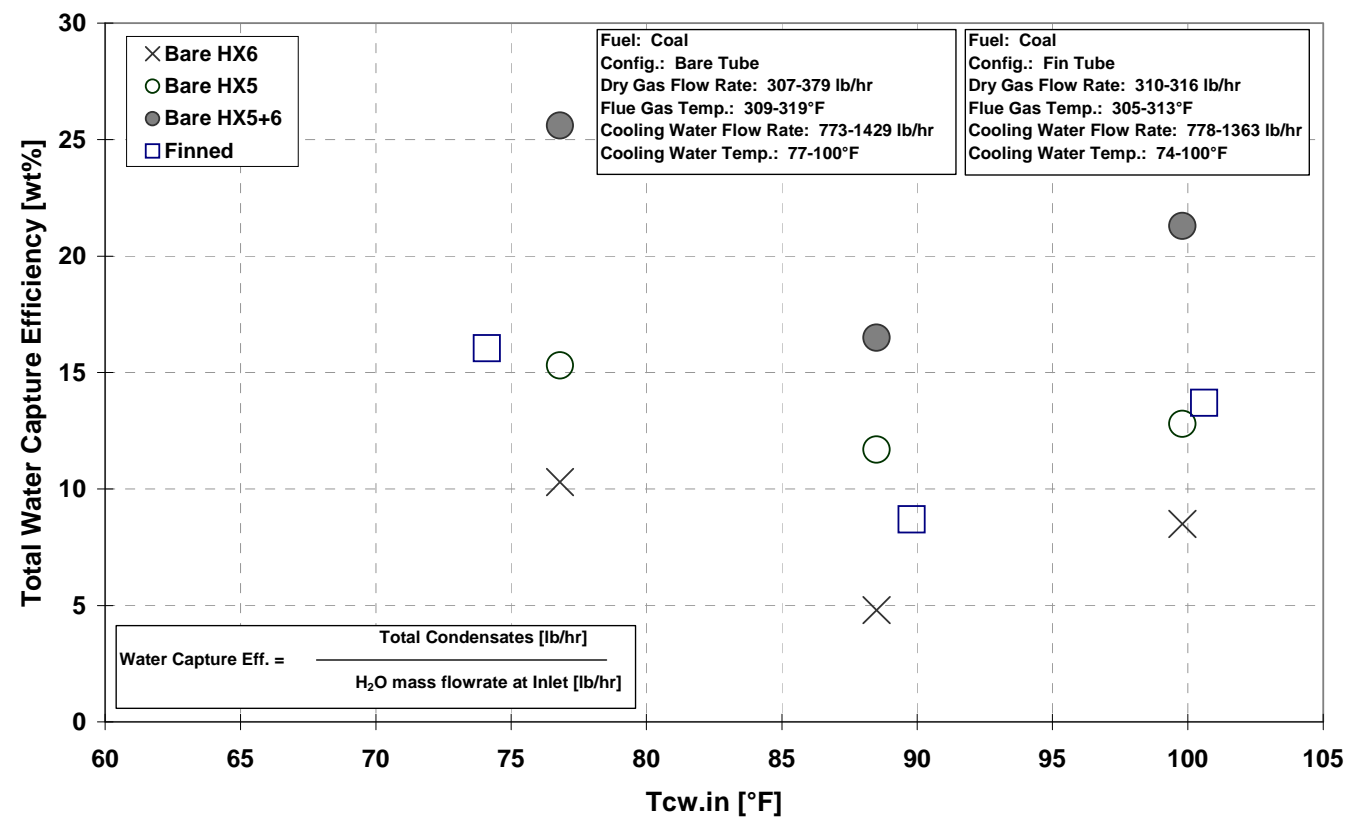

Figure 3-17: Comparison of Water Vapor Capture Efficiencies of HXFin, HX6 and HX5. 


\section{CHAPTER 4}

\section{CAPTURE OF ACIDS AND MERCURY FROM FLUE GAS}

\section{Sulfuric Acid Capture}

Oil-Fired Test Data. Figure 4-1 shows flue gas sulfuric acid concentration data obtained during three oil-fired tests, and Figure 4-2 shows average values and standard deviations for the same data set. These data show a rapid rate of capture of $\mathrm{H}_{2} \mathrm{SO}_{4}$ within heat exchanger $\mathrm{HX} 2$, followed by a limited decrease in $\mathrm{H}_{2} \mathrm{SO}_{4}$ concentration within heat exchangers $\mathrm{HX} 3$ to HX6. Figure 4-3, which contains data for the corresponding change in flue gas water vapor concentration during these same tests, shows no decrease in water vapor concentration within heat exchangers HX2 and HX3, followed by a decrease from 11 volume $\%$ to approximately 2 volume $\%$ within heat exchangers HX4 to HX6.

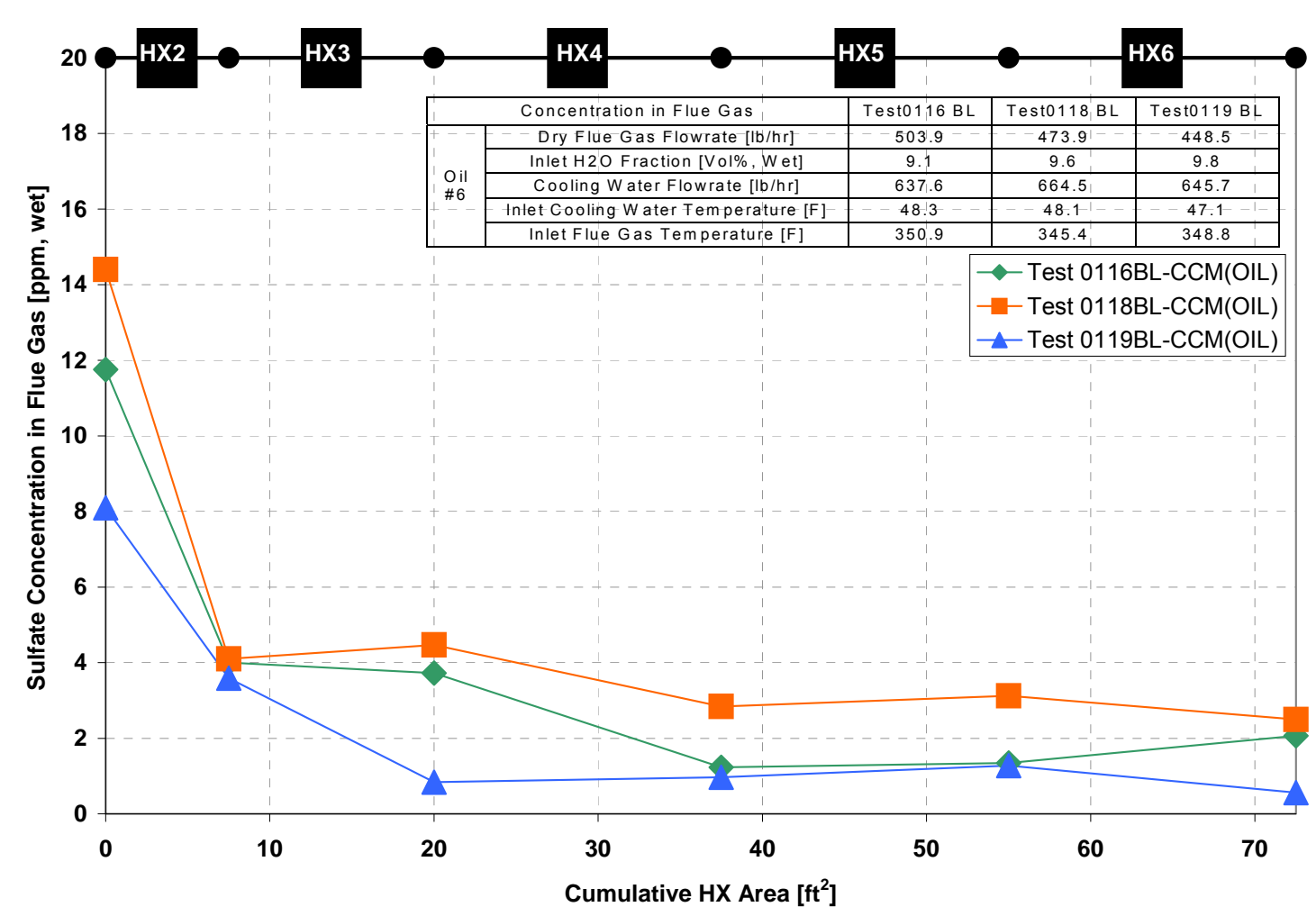

Figure 4-1: Axial Variations of Flue Gas Sulfuric Acid Concentration. Oil Test Data with $48^{\circ} \mathrm{F}$ Inlet Cooling Water Temperature. 


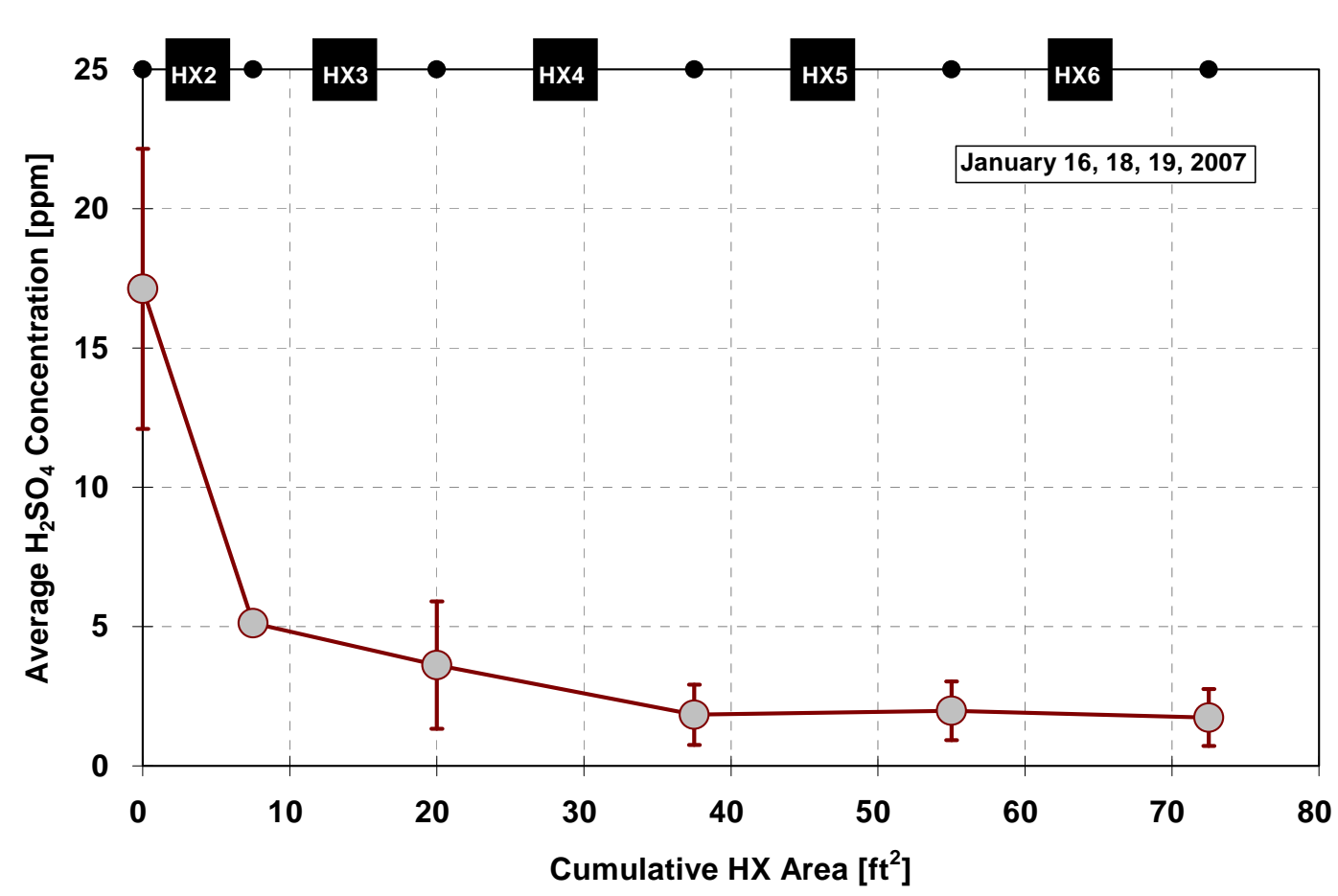

Figure 4-2: Axial Variation of Average Flue Gas Sulfuric Acid Concentration. Oil Test Data with $48^{\circ} \mathrm{F}$ Inlet Cooling Water Temperature.

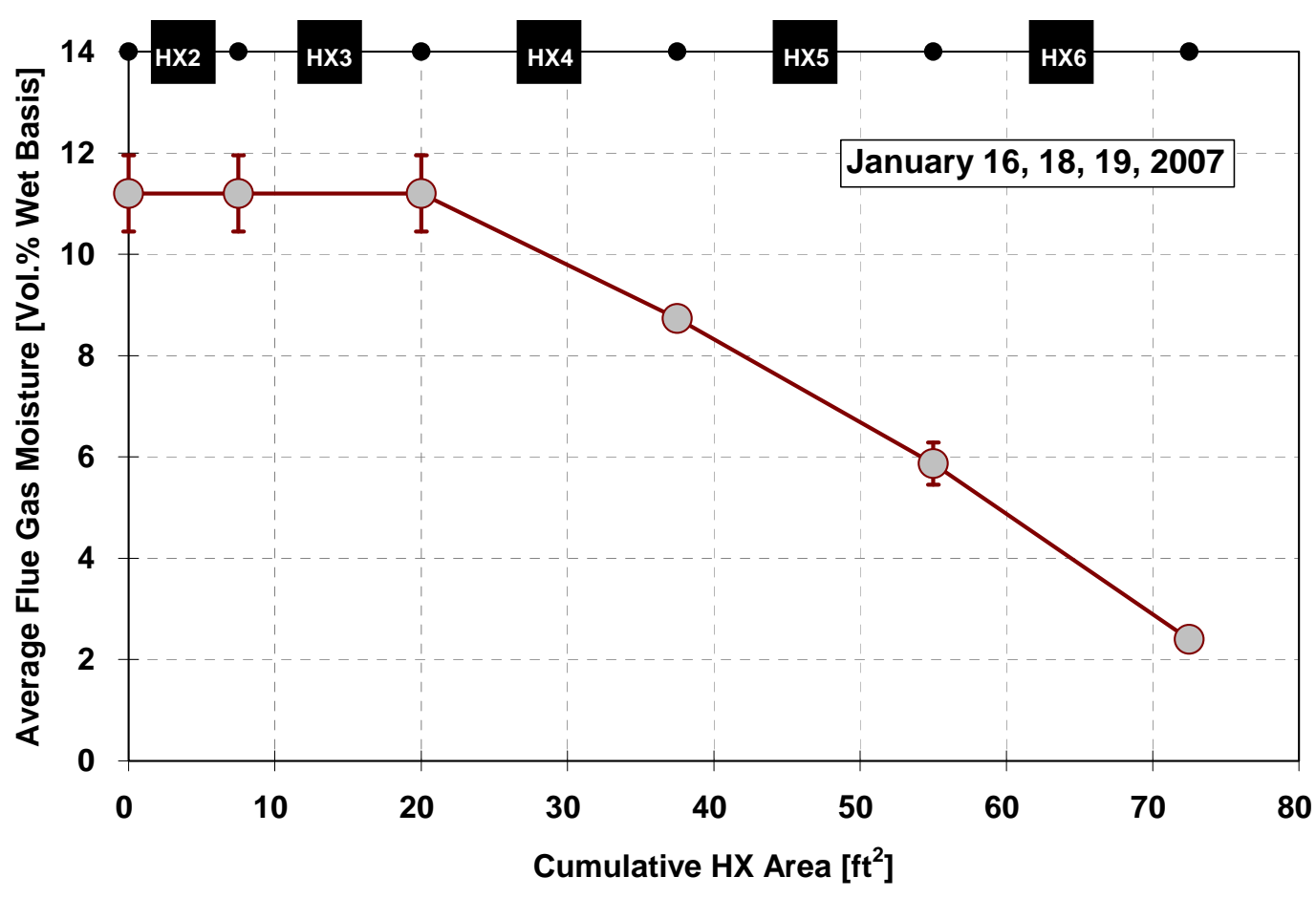

Figure 4-3: Axial Variation of Water Vapor Concentration. Oil Test Data with $48^{\circ} \mathrm{F}$ Inlet Cooling Water Temperature. 
The reasons for the separation of the acid capture and water vapor condensation into high and low temperature zones can be seen from Figures 4-4 to 4-6 which show the axial variation of tube wall temperature for these tests and the dew points for $\mathrm{H}_{2} \mathrm{O}$ and $\mathrm{H}_{2} \mathrm{SO}_{4}$ (Ref. 4). With an acid dew point above $200^{\circ} \mathrm{F}$ and a water vapor dew point below $120^{\circ} \mathrm{F}$, acid condensation began within heat exchanger $\mathrm{HX} 2$ and the onset of water vapor condensation was delayed until heat exchanger HX4.

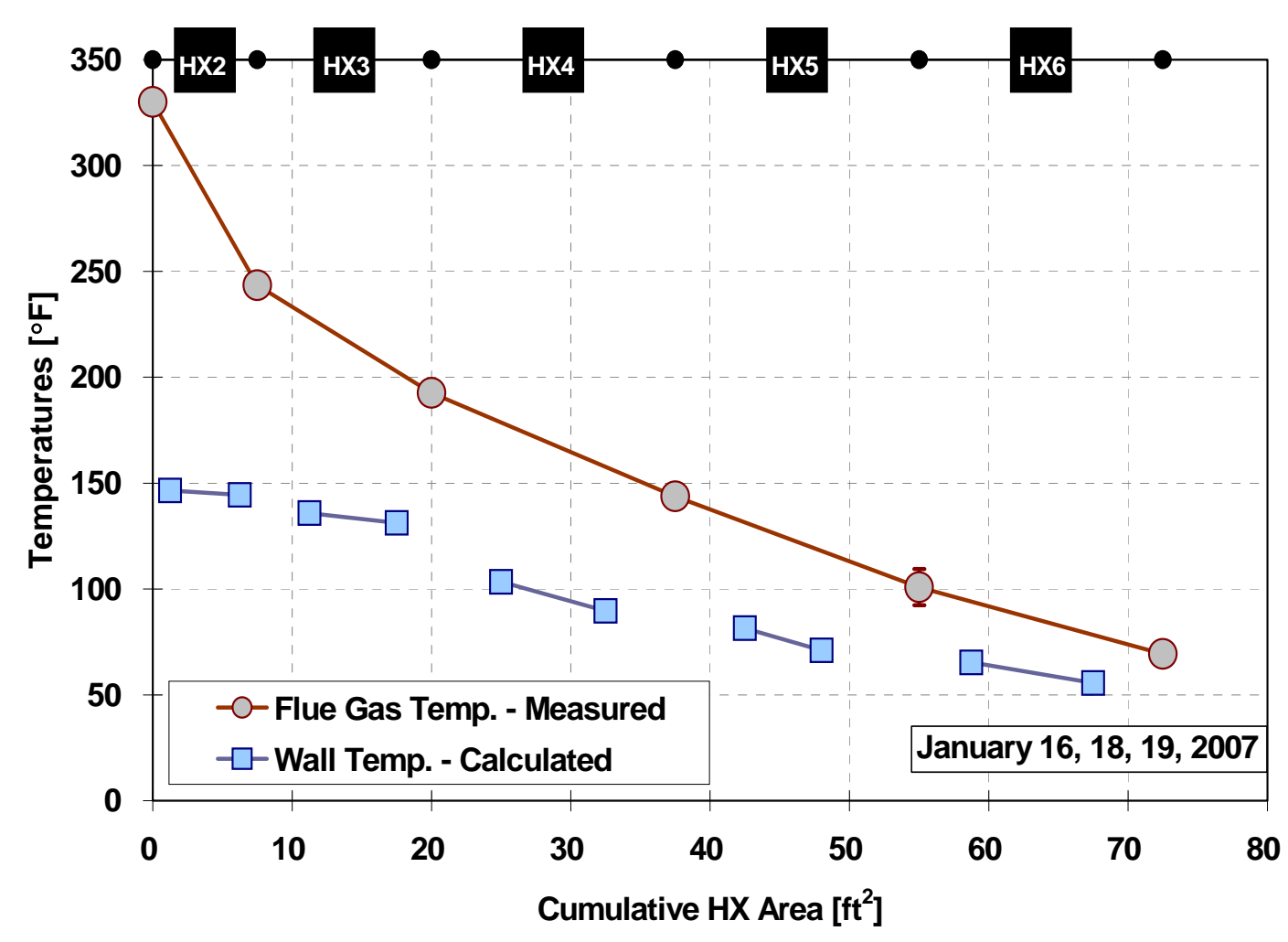

Figure 4-4: Axial Variations of Flue Gas and Tube Wall Temperatures. Oil Test Data with $48^{\circ} \mathrm{F}$ Inlet Cooling Water Temperature. 


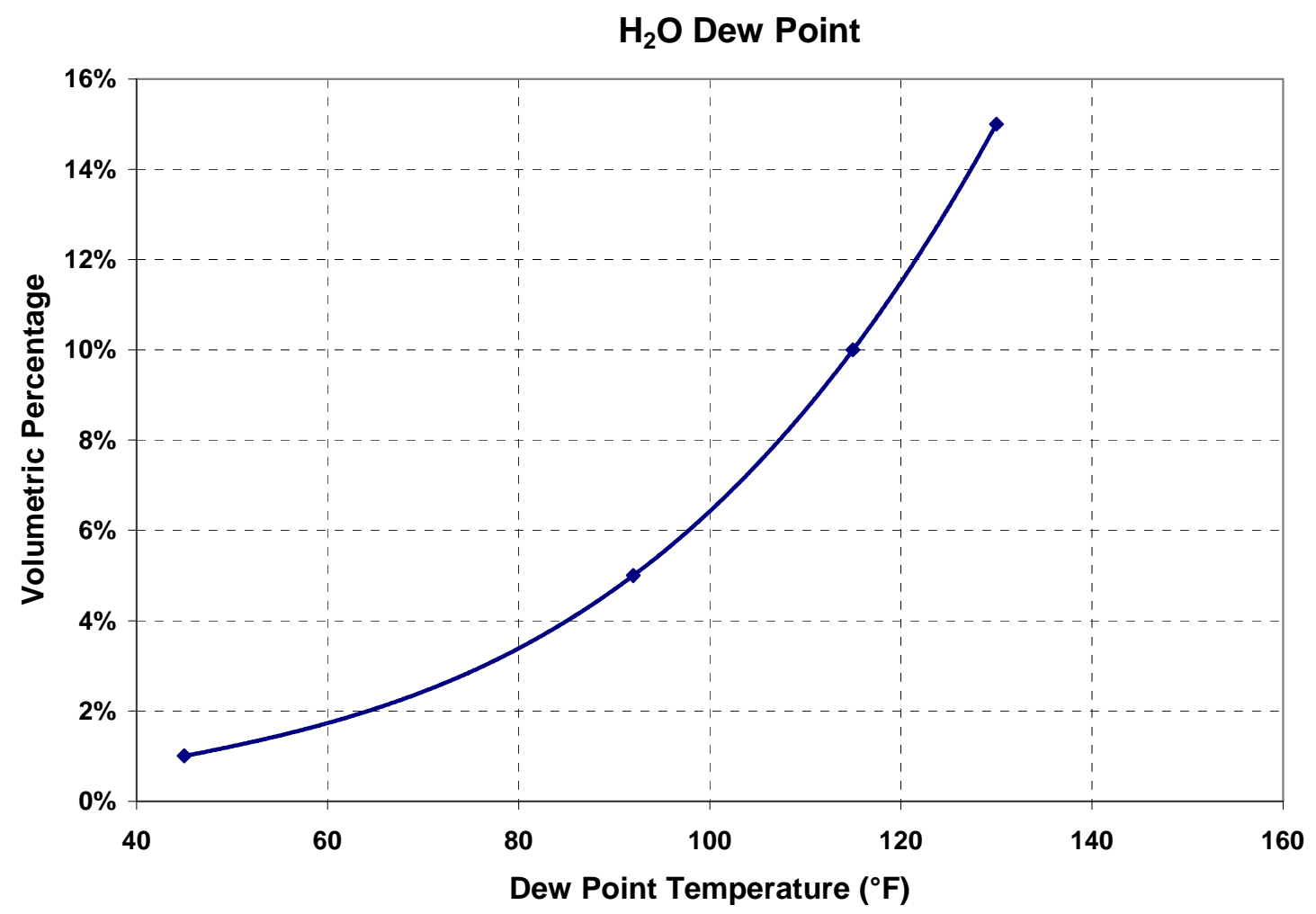

Figure 4-5: Water Vapor Dew Point Temperature vs. Volumetric Concentration.

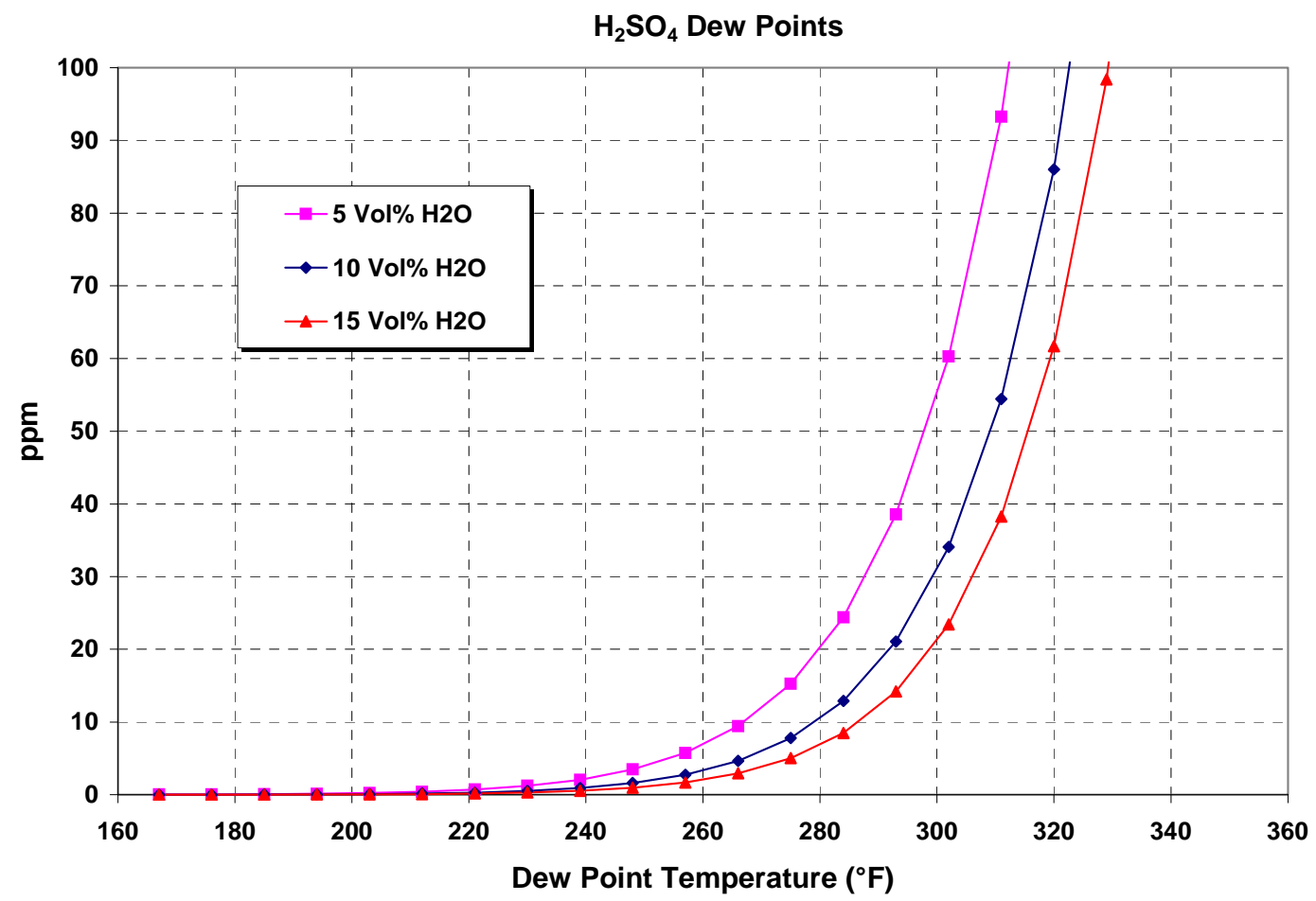

Figure 4-6: Sulfuric Acid Dew Point Temperature vs. Acid and Water Vapor Volumetric Concentrations. 
Coal-Fired Test Data. Somewhat different results for sulfuric acid condensation were obtained during the coal-fired tests. Figure 4-7 shows flue gas sulfuric acid vapor concentrations for inlet cooling water temperatures of $76^{\circ}$ and $100^{\circ} \mathrm{F}$, and this shows in both cases, the sulfuric acid concentrations decreased at a much more gradual rate than they did with flue gas from oil-firing. The corresponding flue gas moisture fraction and temperature and tube wall temperature variations are shown in Figures 4-8 and 4-9 for tests with a $77^{\circ} \mathrm{F}$ inlet cooling water temperature. The reasons for the differences between sulfuric acid condensation in the coal and oil-based flue gas will be studied in a follow-on investigation.

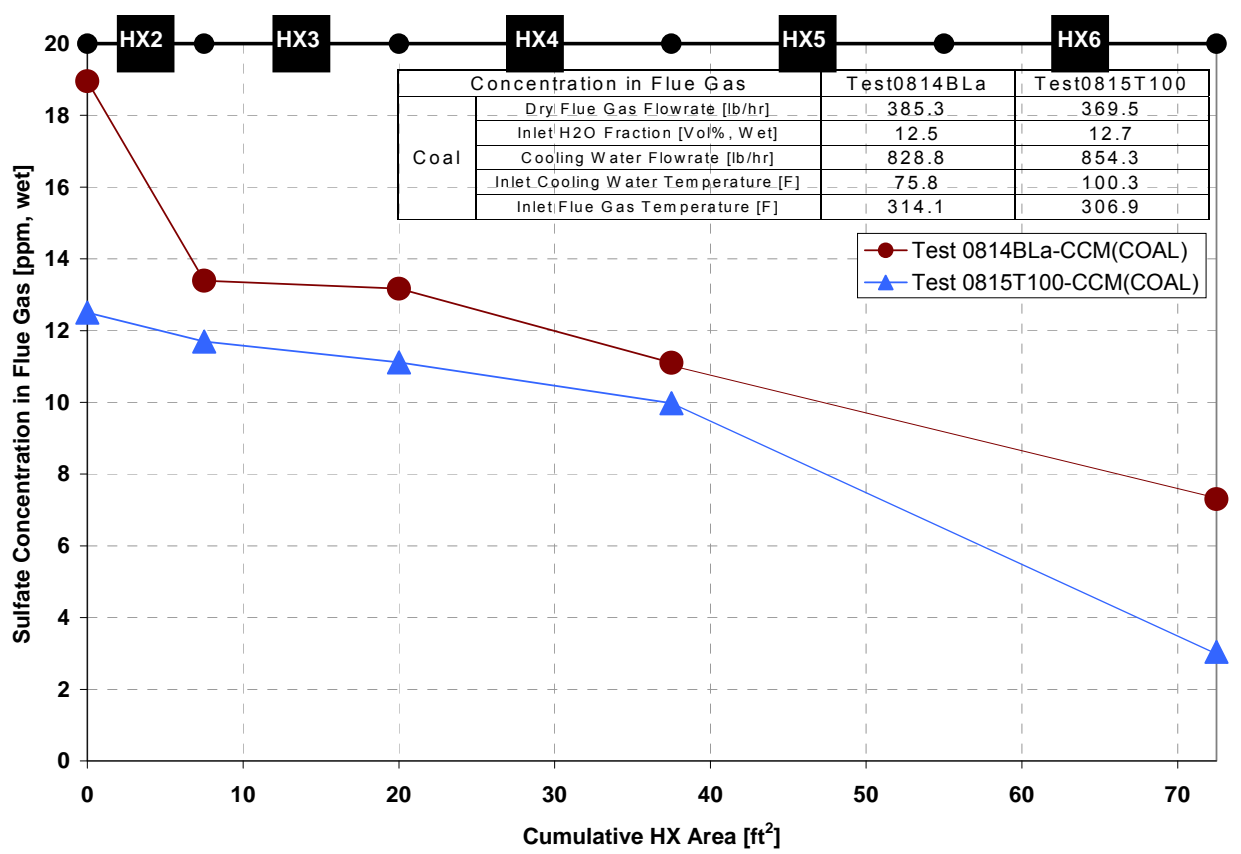

Figure 4-7: Axial Variations of Flue Gas Sulfuric Acid Concentration. Coal Test Data with $76^{\circ} \mathrm{F}$ and $100^{\circ} \mathrm{F}$ Inlet Cooling Water Temperatures. 


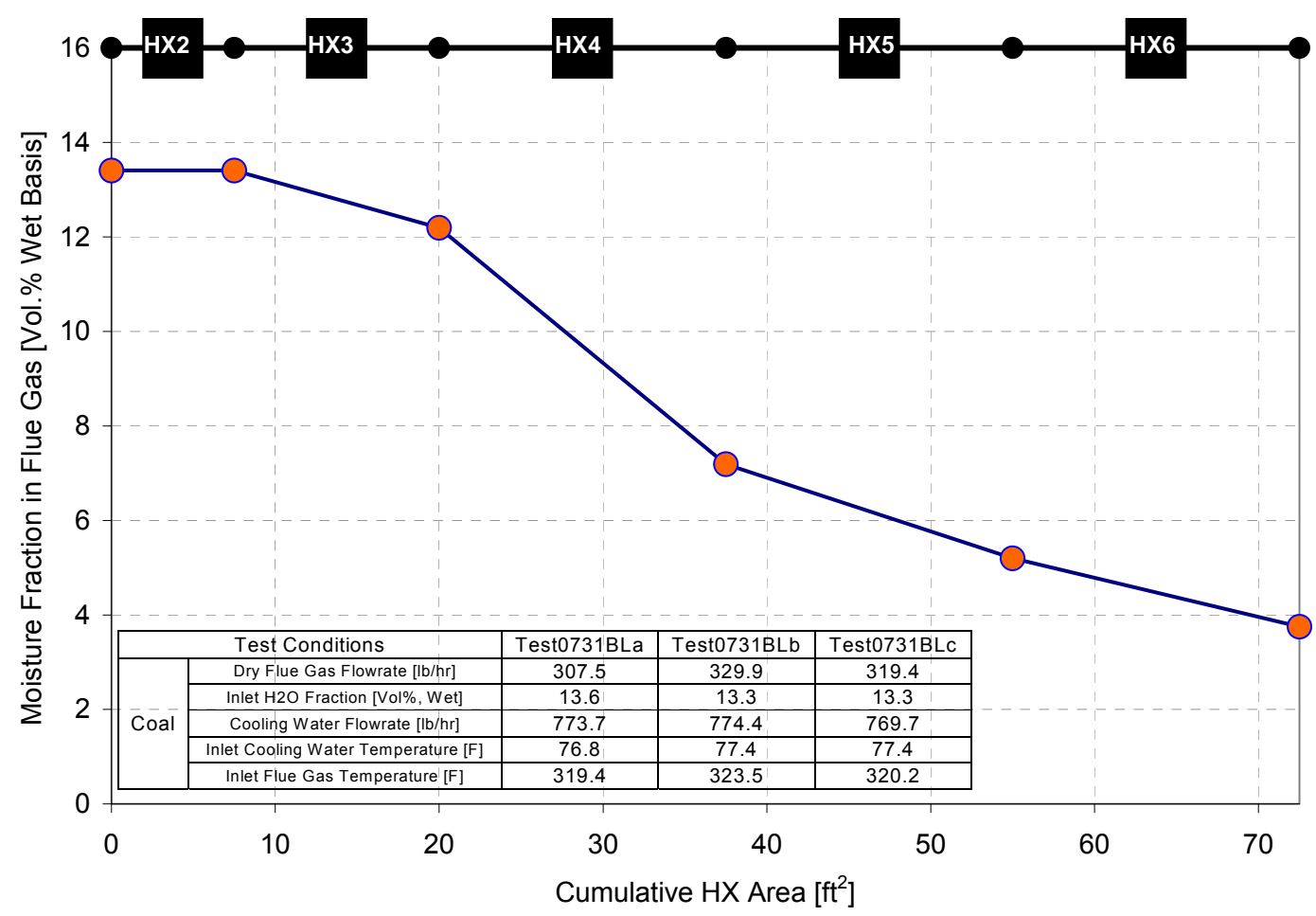

Figure 4-8: Axial Variation of Water Vapor Concentration. Coal Test Data with $77^{\circ} \mathrm{F}$ Inlet Cooling Water Temperature.

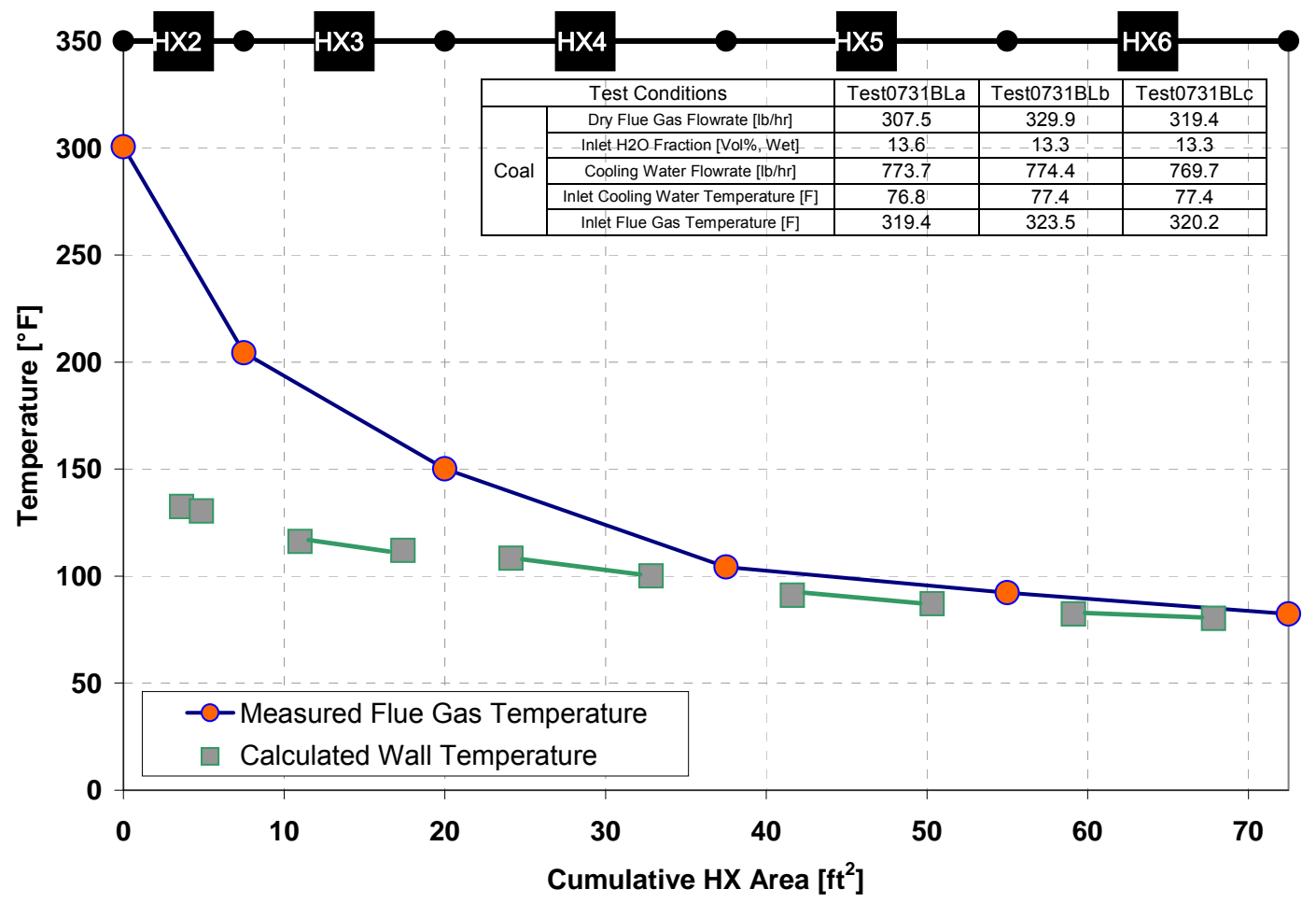

Figure 4-9: Axial Variations of Flue Gas and Tube Wall Temperatures. Coal Test Data with $77^{\circ} \mathrm{F}$ Inlet Cooling Water Temperature. 


\section{Nitrate and Chloride Capture}

Oil-Fired Test Data. Samples of condensed water from the oil-fired tests were analyzed for chloride and nitrate ions. Figures 4-10 and 4-11 show nitrate concentrations in the water condensate from each heat exchanger and the nitrate flow rates as a function of wall temperature. Figures $4-12$ and $4-13$ show comparable results for chloride concentrations and flow rates. Comparison of the chloride concentrations and flow rates to the values for nitrates show the absorbed nitrates were smaller in magnitude than the chlorides by a factor of 10 . The flow rate versus temperature plots confirm that $\mathrm{HCl}$ and $\mathrm{HNO}_{3}$ condense in the same range of temperatures as $\mathrm{H}_{2} \mathrm{O}$. This finding is consistent with equations for acid dewpoints given in Reference 5 and plotted in Figure 4-14.

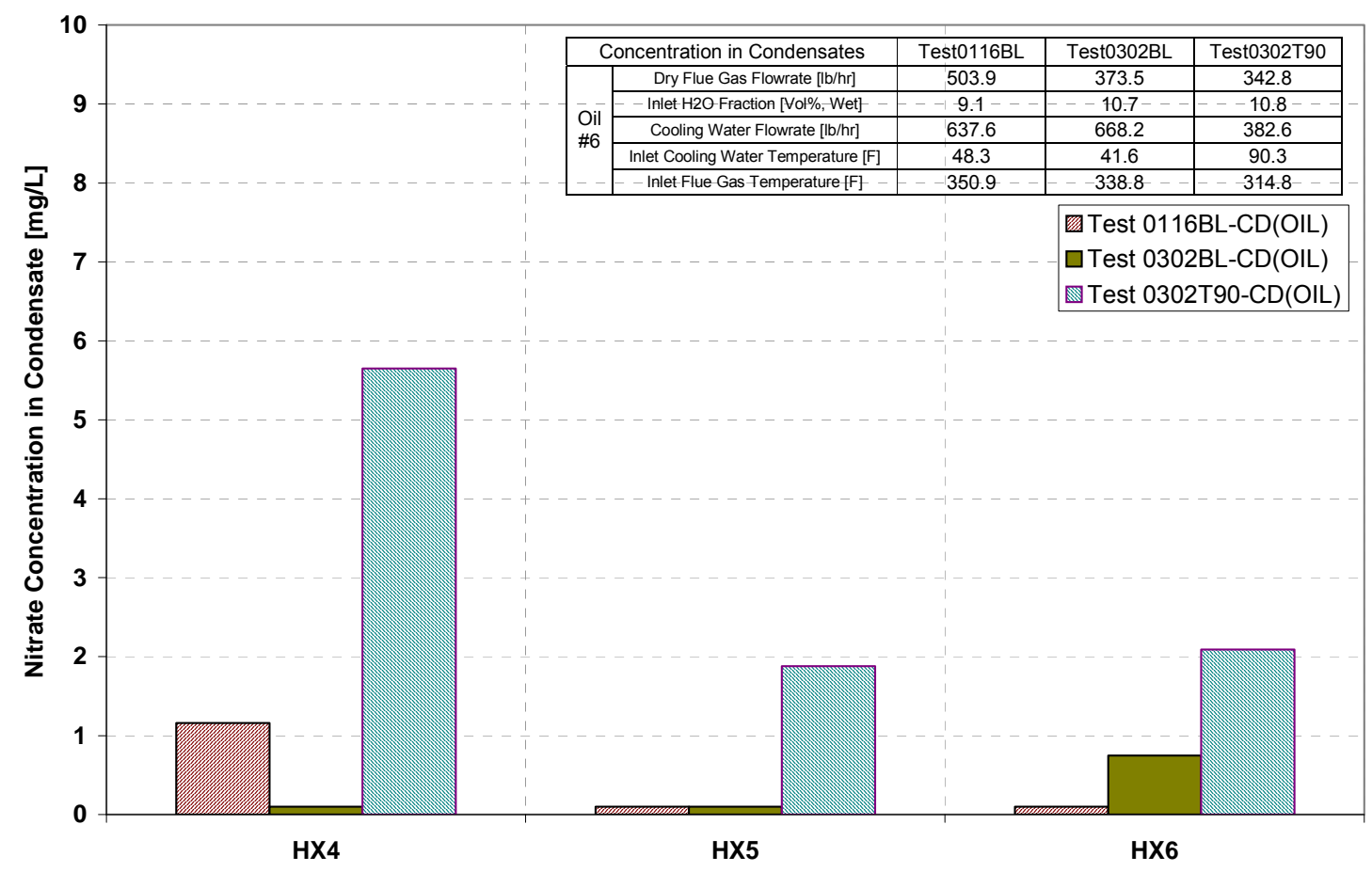

Figure 4-10: Nitrate Concentration in Condensed Water Vapor from Heat Exchangers HX4 to HX6. Oil Test Data with Inlet Cooling Water Temperatures from 42 to $90^{\circ} \mathrm{F}$. 


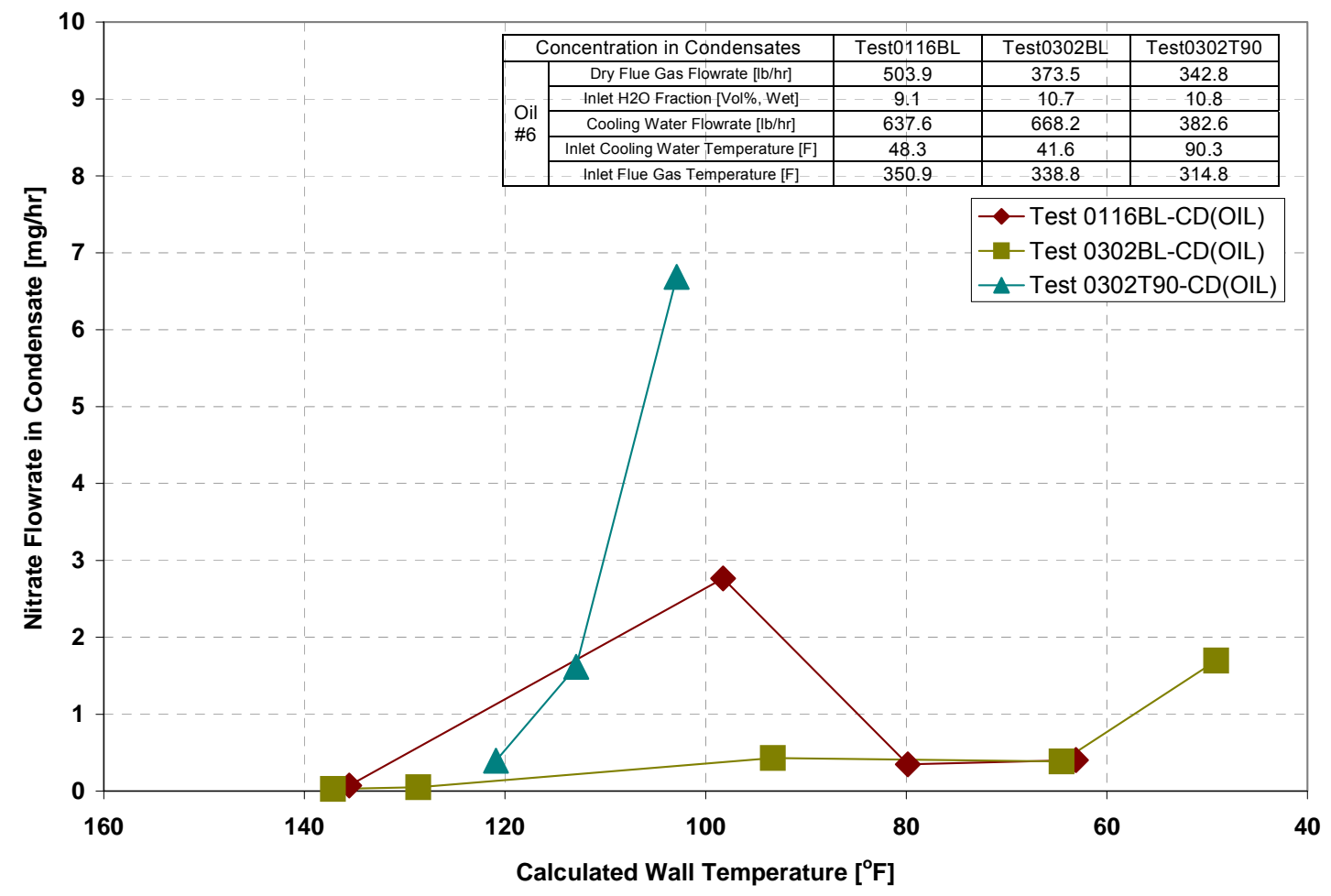

Figure 4-11: Nitrate Flow Rates from Heat Exchangers HX4 to HX6 versus Tube Wall Temperature. Oil Test Data with Inlet Cooling Water Temperatures from 42 to $90^{\circ} \mathrm{F}$.

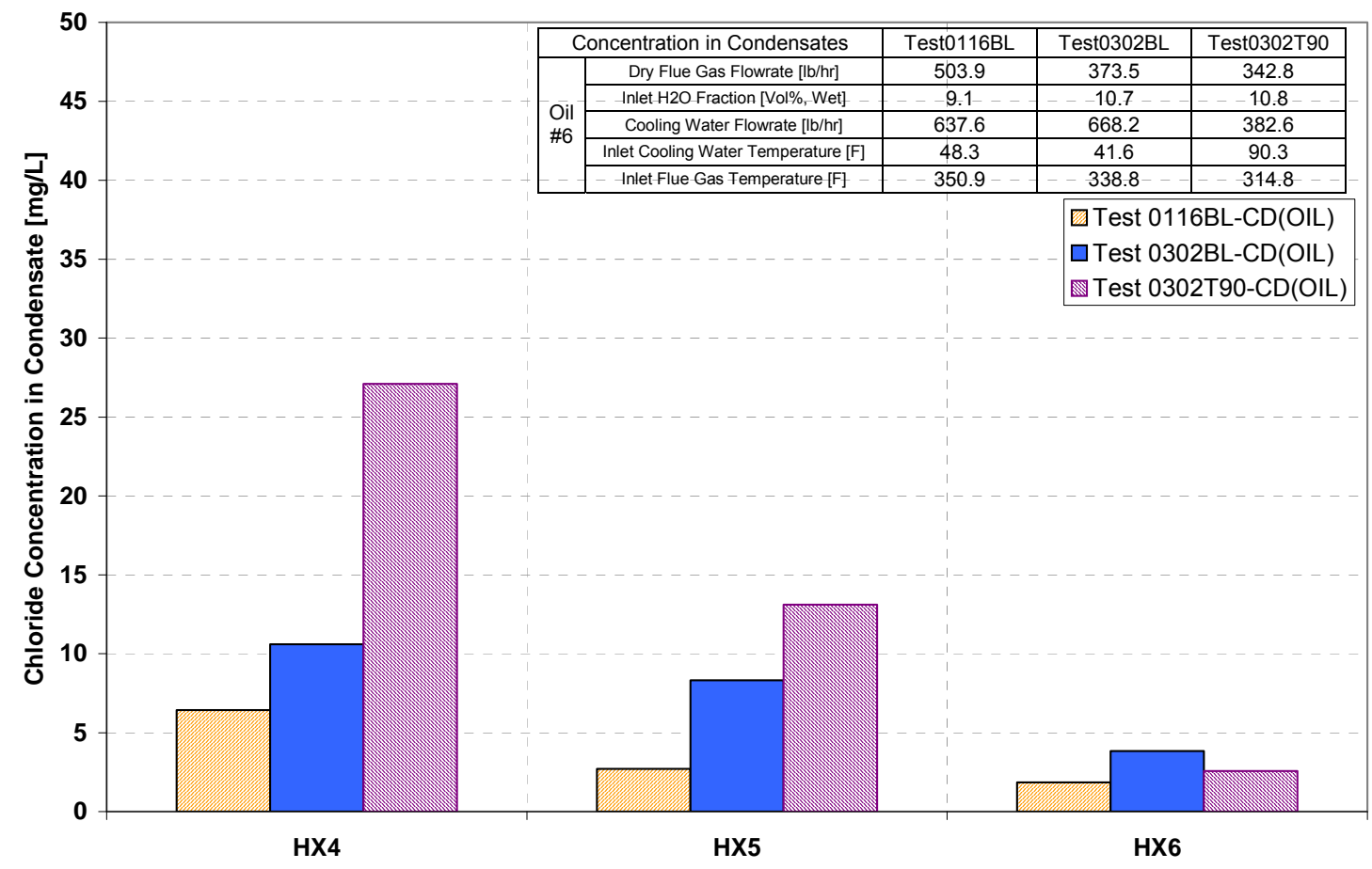

Figure 4-12: Chloride Concentration in Condensed Water Vapor from Heat Exchangers HX4 to HX6. Oil Test Data with Inlet Cooling Water Temperatures from 42 to $90^{\circ} \mathrm{F}$. 


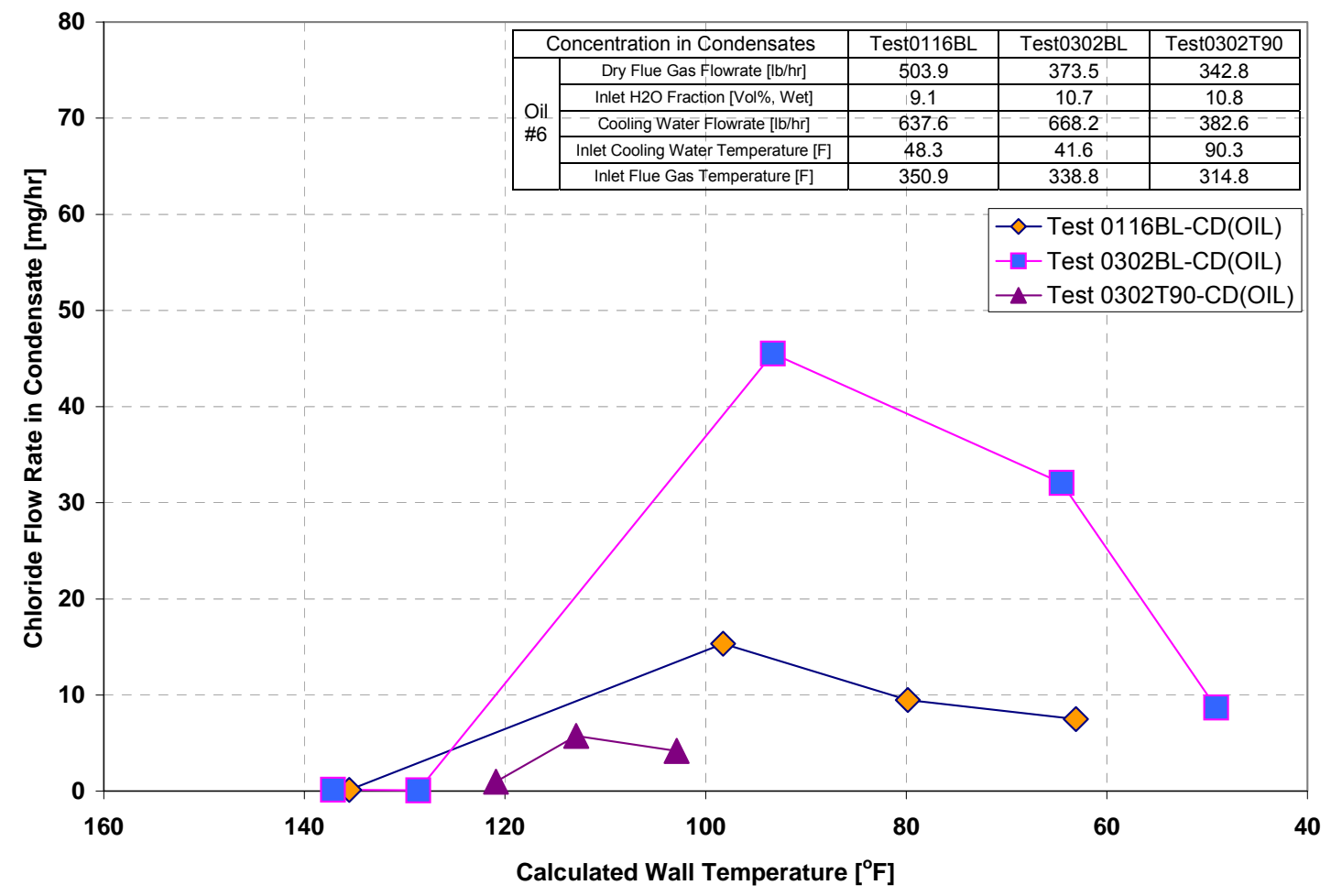

Figure 4-13: Chloride Flow Rates from Heat Exchangers HX4 to HX6 versus Tube Wall Temperature. Oil Test Data with Inlet Cooling Water Temperatures from 42 to $90^{\circ} \mathrm{F}$.

\section{$\mathrm{HCl}$ and $\mathrm{HNO}_{3}$ Dew Points}

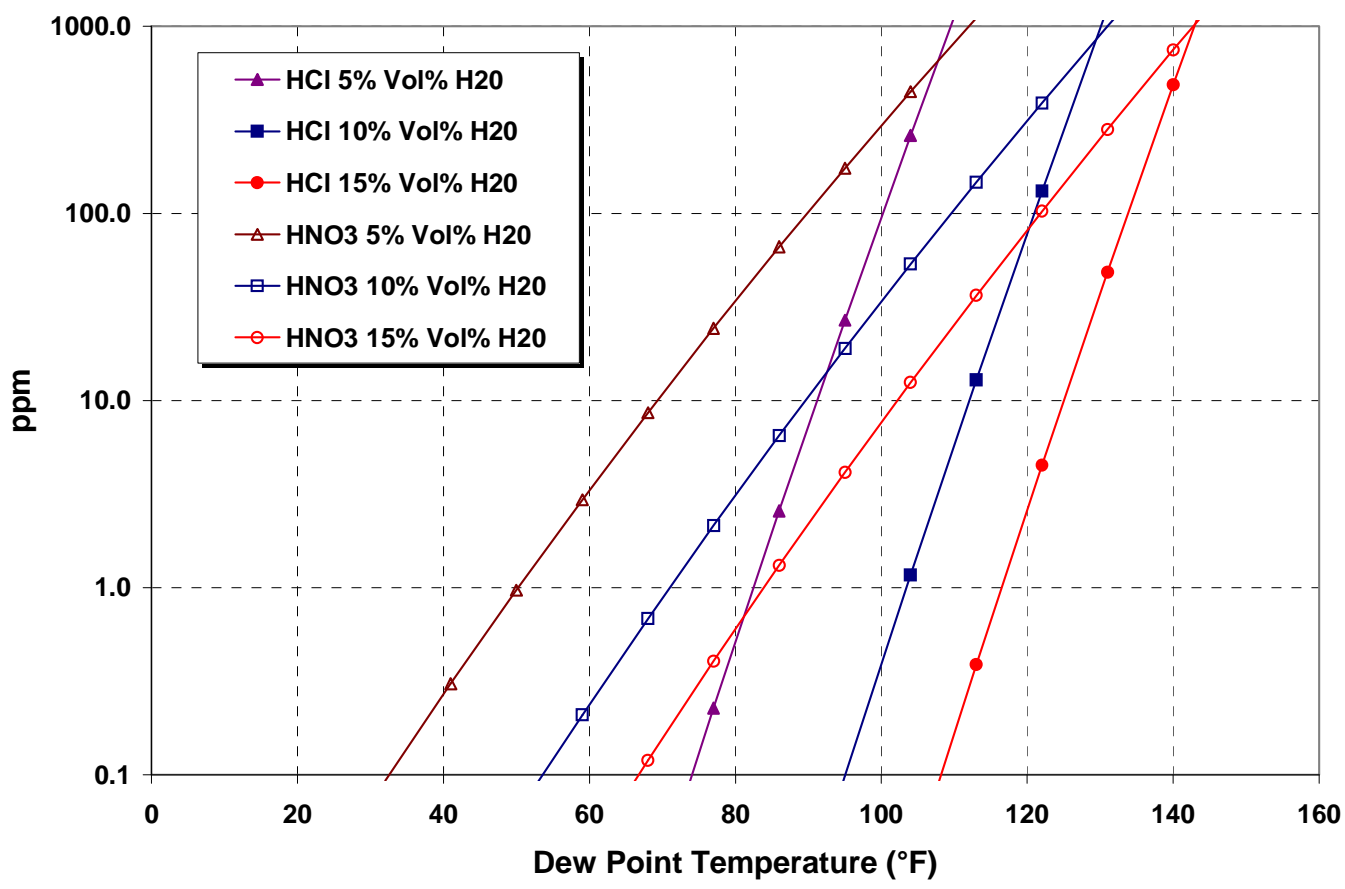

Figure 4-14: $\mathrm{HCl}$ and $\mathrm{HNO}_{3}$ Dew Points versus Acid and Water Vapor Volumetric Concentrations. From Reference 5. 
Coal-Fired Test Data. Figures 4-15 to 4-18, obtained from coal data, give comparable results to the nitrate and chloride capture in the oil-fired tests. Differences between coal and oil in peak concentrations and flow rates are most likely related to differences in chlorine concentration of the two fuels and in $\mathrm{NO}_{x}$ levels in the two flue gases.

\section{Mercury Capture}

Measurements were made of the mercury concentrations at the inlet and outlet of the condensing heat exchanger system during some of the coal-fired tests. These measurements were made using sorbent traps with cooling water inlet temperatures of $70^{\circ} \mathrm{F}$ (Figure 4-19) and $100^{\circ} \mathrm{F}$ (Figure 4-20). The sorbent trap data show flue gas $\mathrm{Hg}$ concentrations entering the heat exchanger system were approximately $3.5 \mathrm{ng} / \mathrm{dscf}$, which is of the same magnitude as had been obtained at that power plant in earlier measurements made at the stack by an environmental testing contractor. The sorbent trap data also indicate approximately a $60 \%$ decrease in flue gas mercury concentration

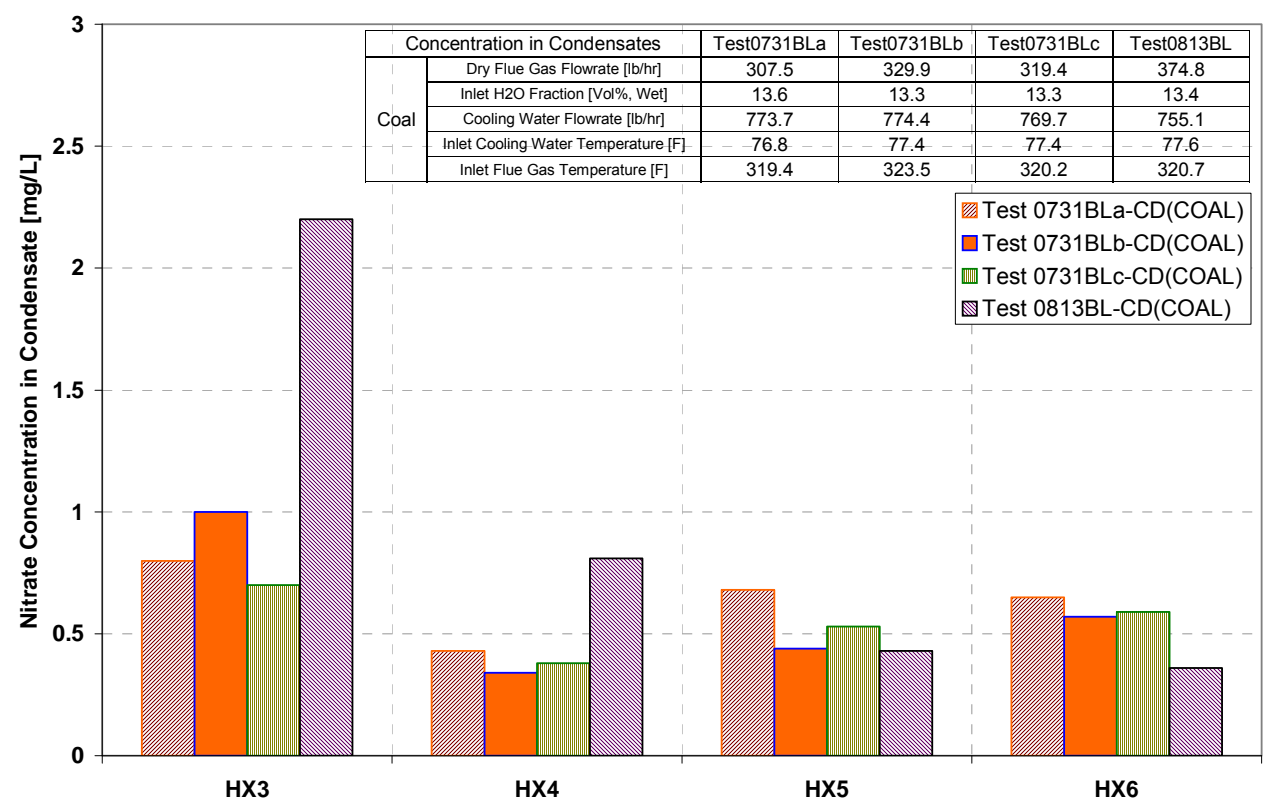

Figure 4-15: Nitrate Concentration in Condensed Water Vapor from Heat Exchangers $\mathrm{HX} 3$ to $\mathrm{HX6}$. Coal Test Data with $77^{\circ} \mathrm{F}$ Inlet Cooling Water Temperature. 


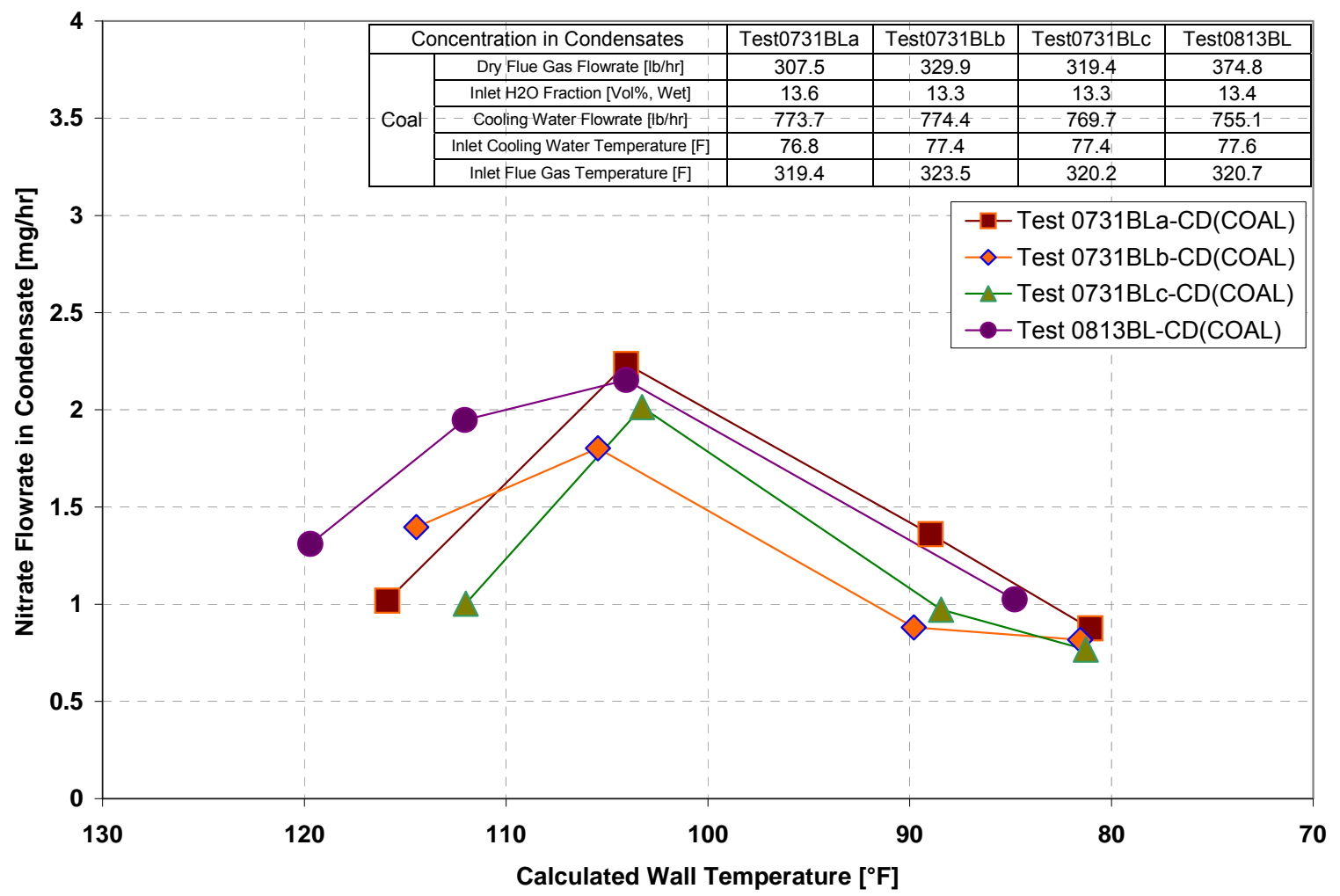

Figure 4-16: Nitrate Flow Rates from Heat Exchangers HX3 to HX6 versus Tube Wall Temperature. Coal Test Data with $77^{\circ} \mathrm{F}$ Inlet Cooling Water Temperature.

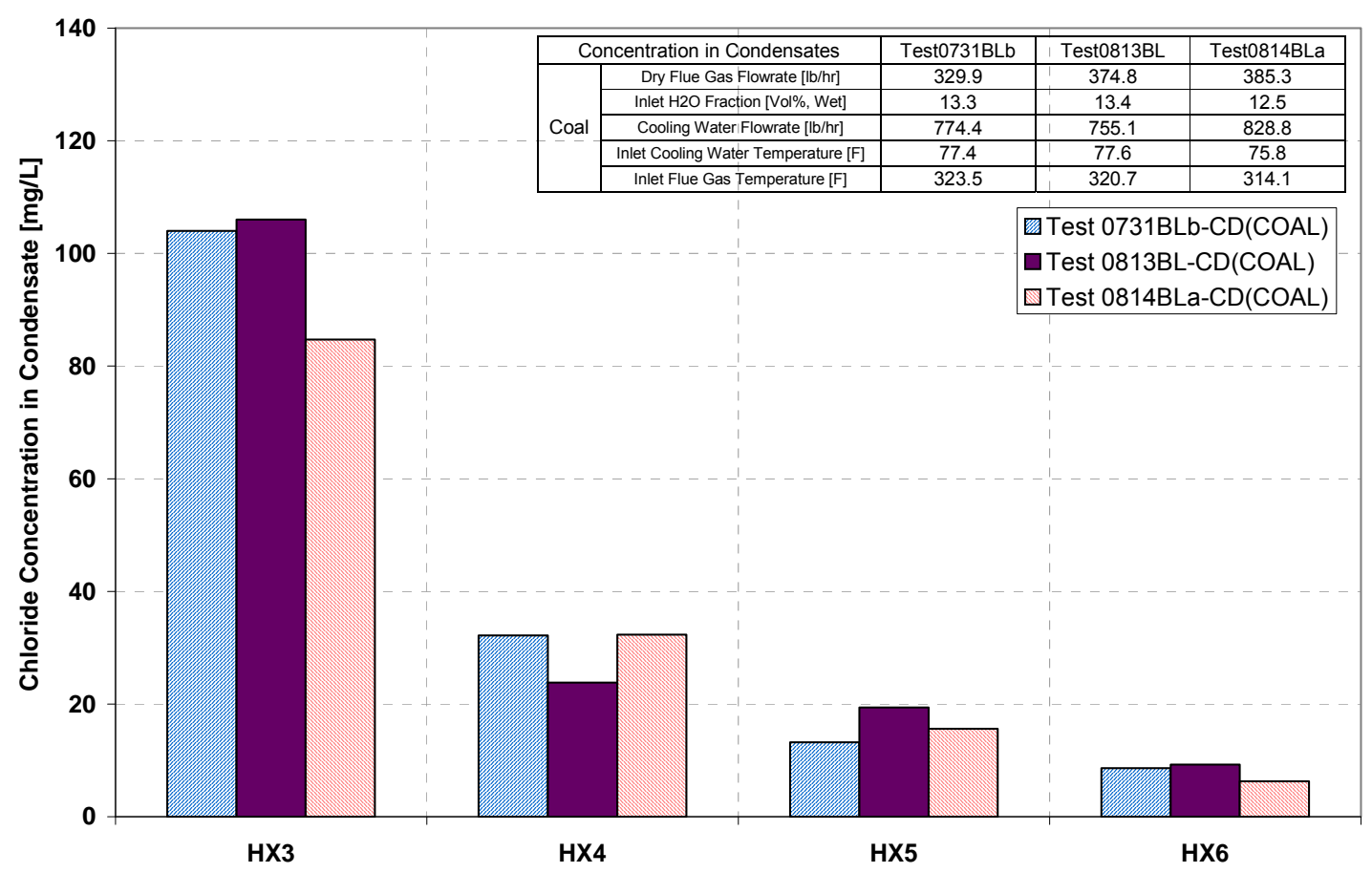

Figure 4-17: Chloride Concentration in Condensed Water Vapor from Heat Exchangers $\mathrm{HX} 3$ to $\mathrm{HX} 6$. Coal Test Data with $77^{\circ} \mathrm{F}$ Inlet Cooling Water Temperature. 


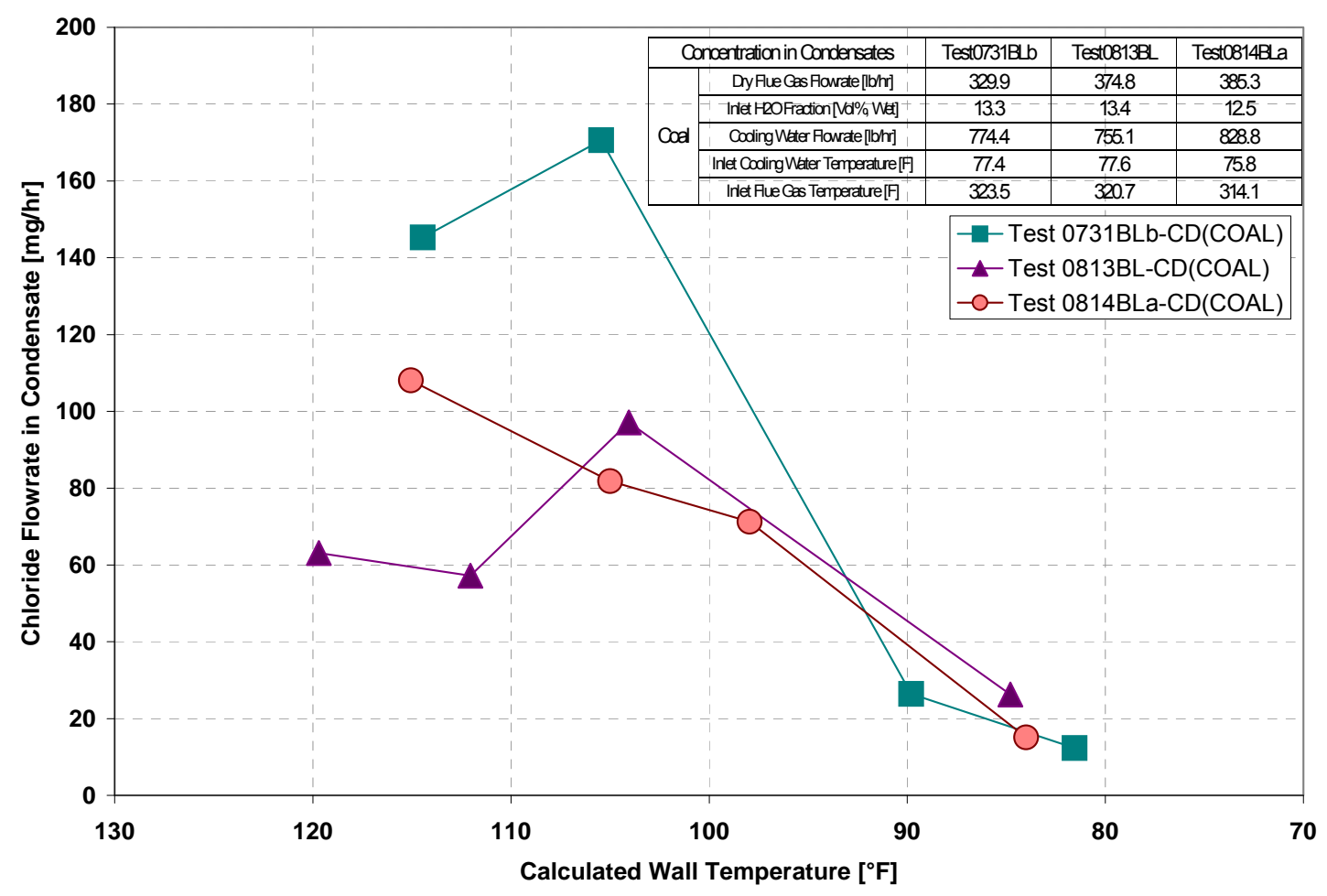

Figure 4-18: Chloride Flow Rates from Heat Exchangers HX3 to HX6 versus Tube Wall Temperature. Coal Test Data with $77^{\circ} \mathrm{F}$ Inlet Cooling Water Temperature.

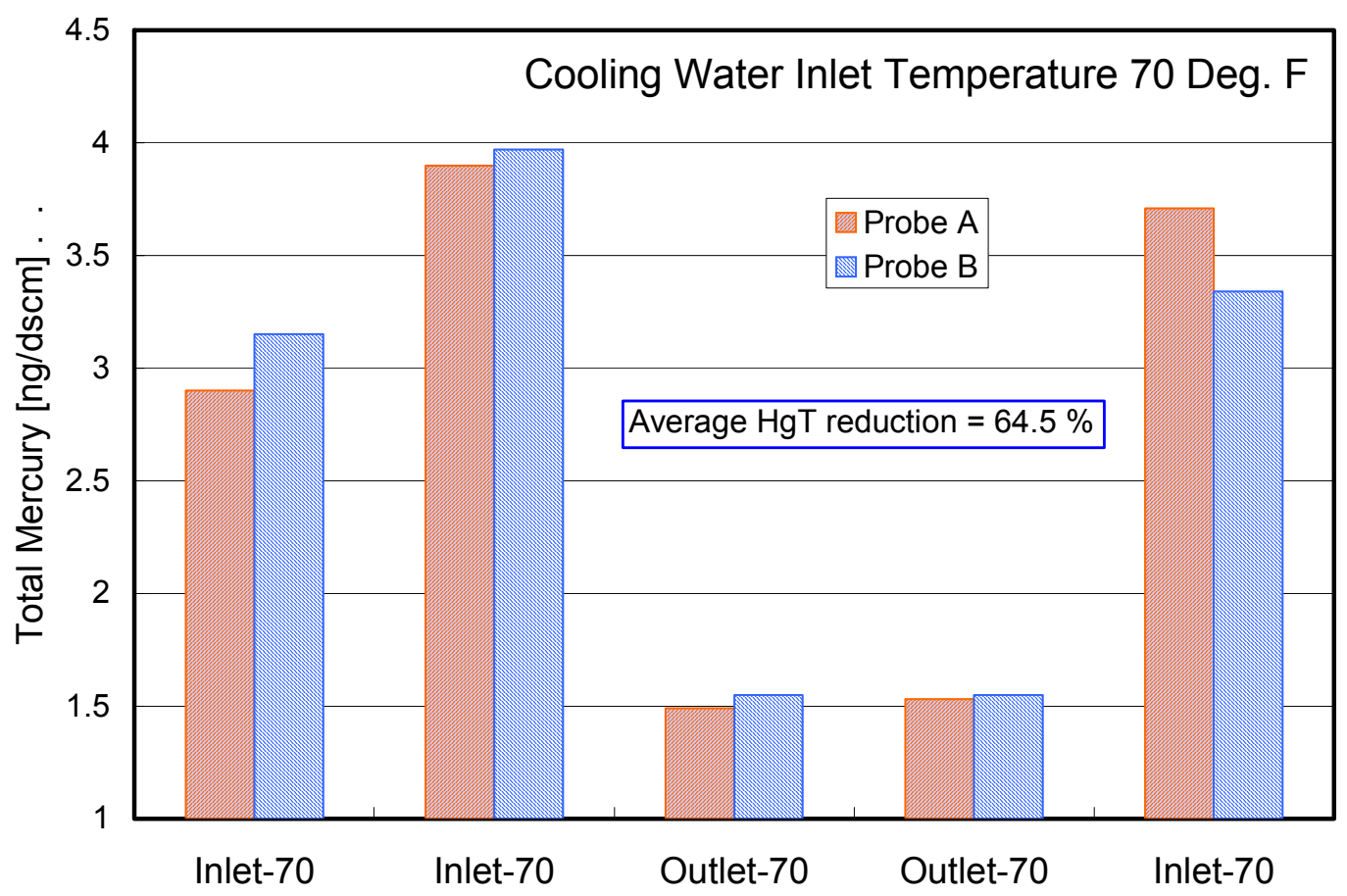

Figure 4-19: Variations of Flue Gas Mercury Concentrations at Inlet and Exit of Condensing Heat Exchanger System as Test Series Progressed. Coal Test Data with $70^{\circ} \mathrm{F}$ Inlet Cooling Water Temperature. 


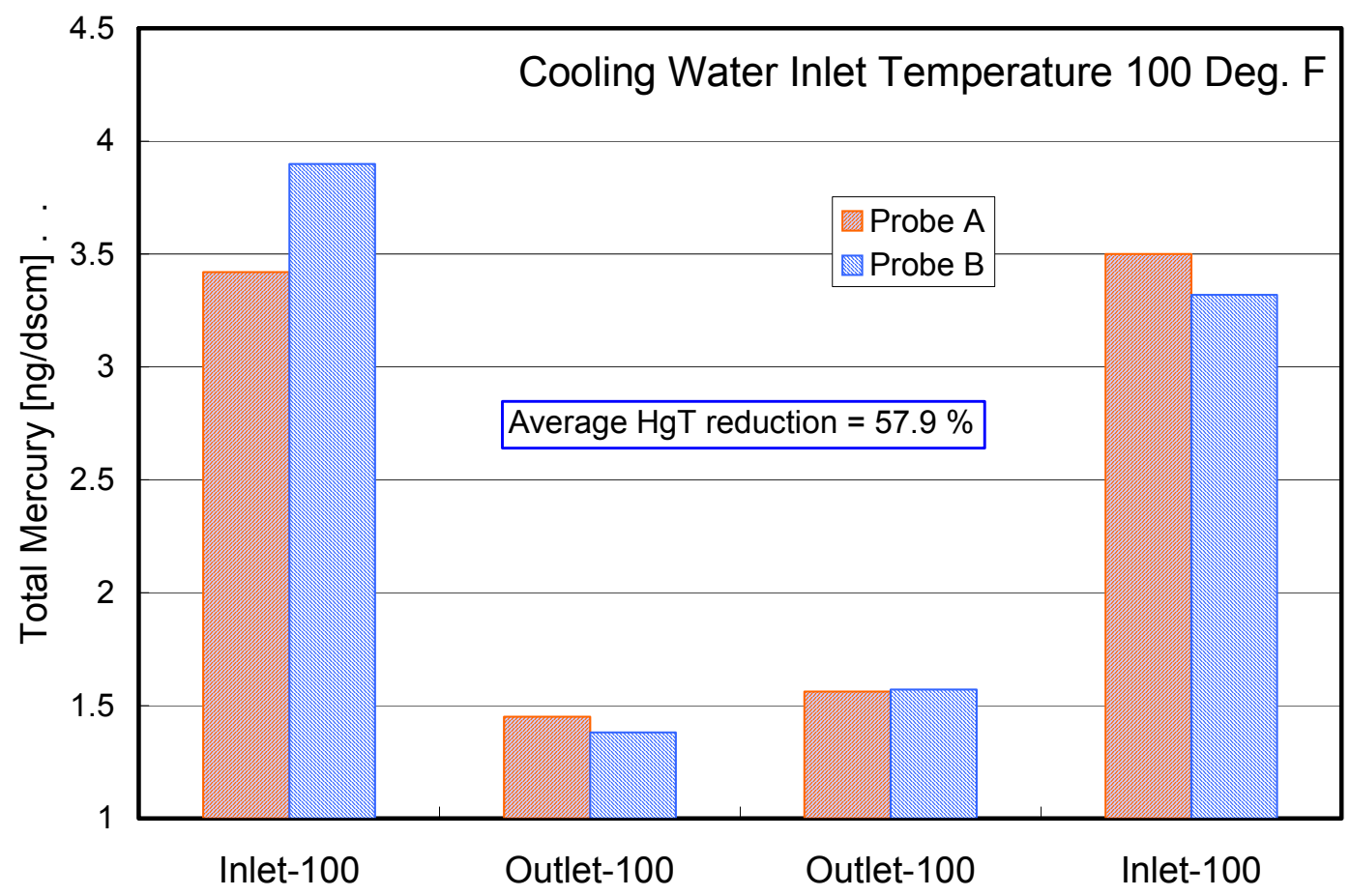

Figure 4-20: Variations of Flue Gas Mercury Concentrations at Inlet and Exit of Condensing Heat Exchanger System as Test Series Progressed. Coal Test Data with $100^{\circ} \mathrm{F}$ Inlet Cooling Water Temperature.

due to the condensing heat exchangers. A comparison of the rate of capture for $70^{\circ} \mathrm{F}$ and $100^{\circ} \mathrm{F}$ inlet cooling water temperatures shows no significant effect of temperature on mercury capture in that temperature range (Figure 4-21).

An attempt was made to obtain a $\mathrm{Hg}$ mass balance, by using measurements of the mercury content of the condensed water flowing from the heat exchangers and the mercury concentrations in the flue gas. A comparison of these mercury flow rates showed the measured difference in flue gas $\mathrm{Hg}$ to be several orders of magnitude larger than the measured rate of $\mathrm{Hg}$ discharge with the condensed water. The authors have been unable to resolve this discrepancy. 


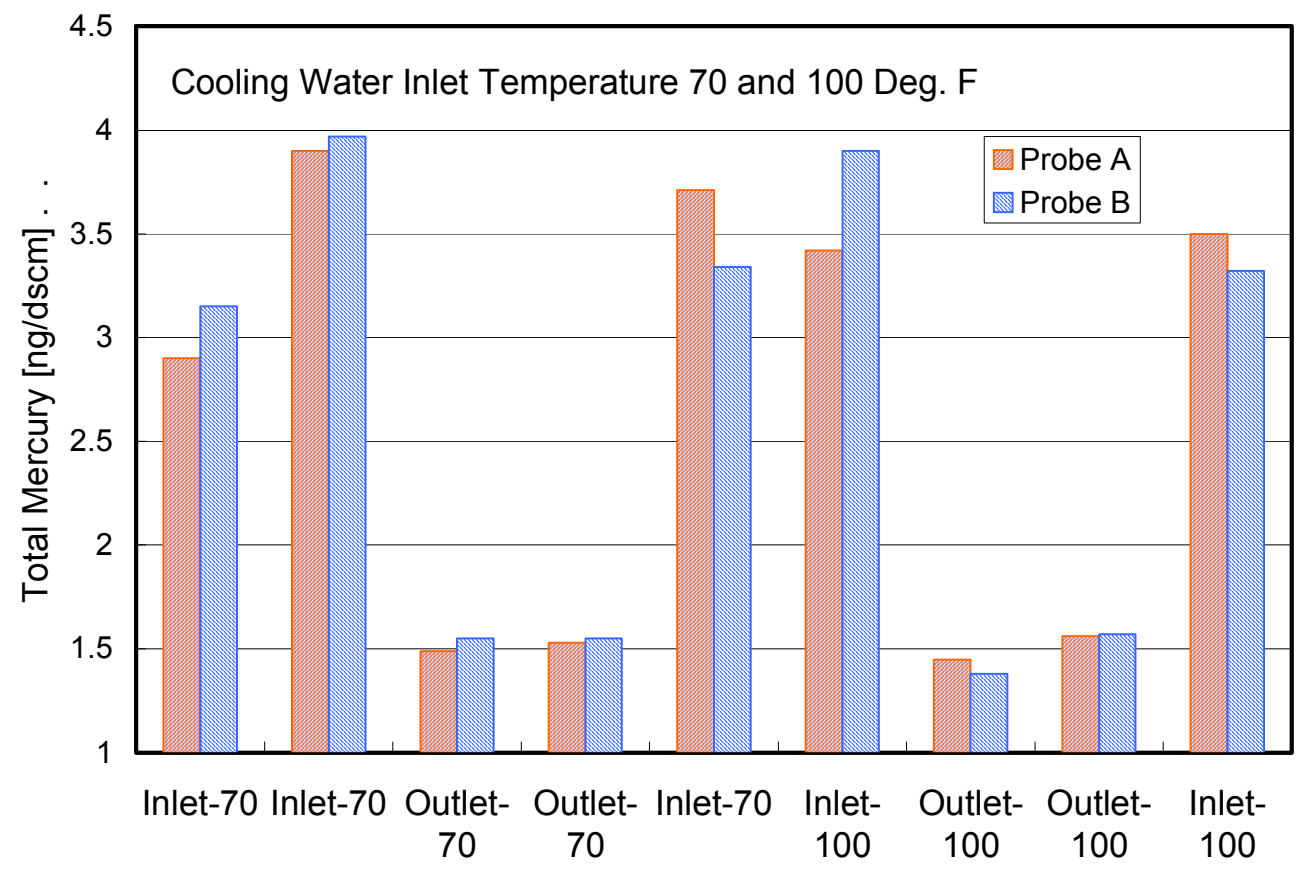

Figure 4-21: Variations in Flue Gas Mercury Concentrations at Inlet and Exit of Condensing Heat Exchanger System as Test Series Progressed. Coal Test Data with $70^{\circ} \mathrm{F}$ and $100^{\circ} \mathrm{F}$ Inlet Cooling Water Temperature. 


\section{CHAPTER 5}

\section{THEORETICAL MODEL OF}

\section{WATER VAPOR CONDENSATION AND COMPARISON TO PILOT-SCALE DATA}

A theoretical model of the heat and mass transfer processes in the heat exchanger system (Figure 5-1) was developed using theoretical relations for heat transfer from the flue gas to the cooling water and for diffusion of water vapor from the flue gas to the tube wall and subsequent water vapor condensation. The model was used to simulate the process conditions encountered in the slip stream tests. This section of the report contains comparisons of theoretical predictions with pilot scale measurements.

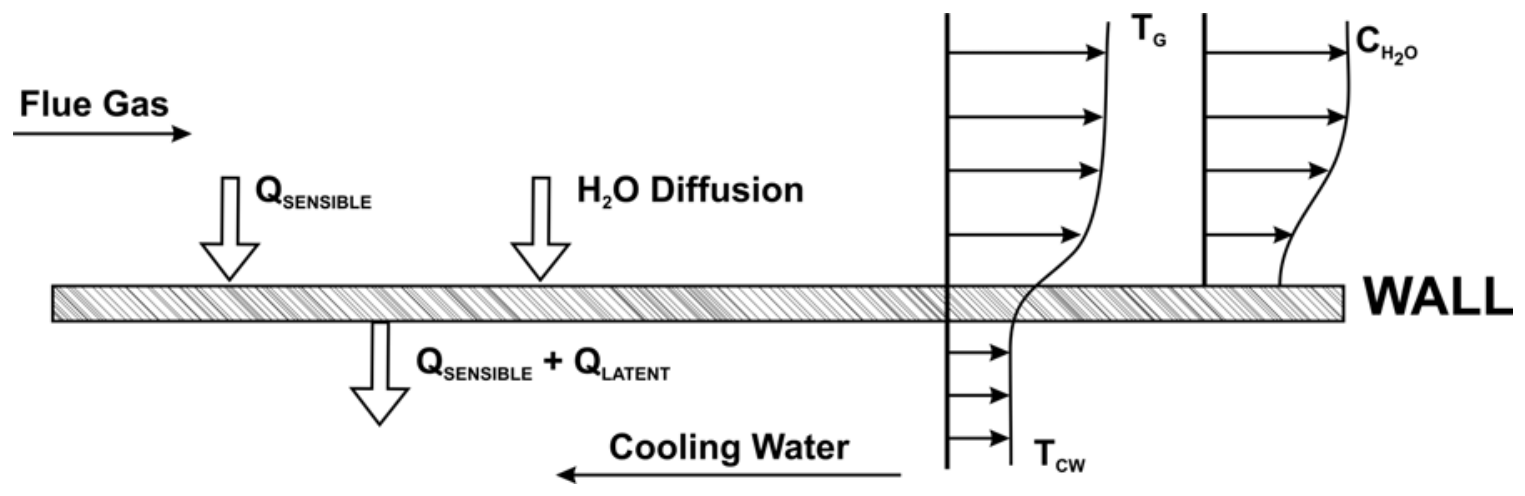

Figure 5-1: Sketch of Heat and Mass Transfer Processes in Condensing Heat Exchanger.

The experimental apparatus used for the pilot scale tests which are described in this section consisted of six tube bundles arranged in series (Figure 5-2), with the heat exchangers designated as HX1 to HX6. Hot flue gas entered HX1 from the left of the diagram and cold cooling water entered $\mathrm{HX} 6$ from the right side of the diagram. For all the test conditions described in this report, the inlet flue gas temperature was close enough to $300^{\circ} \mathrm{F}$ so that the cooling capacity of $\mathrm{HX} 1$ was not needed, and for these tests, the cooling water bypassed heat exchanger HX1. 


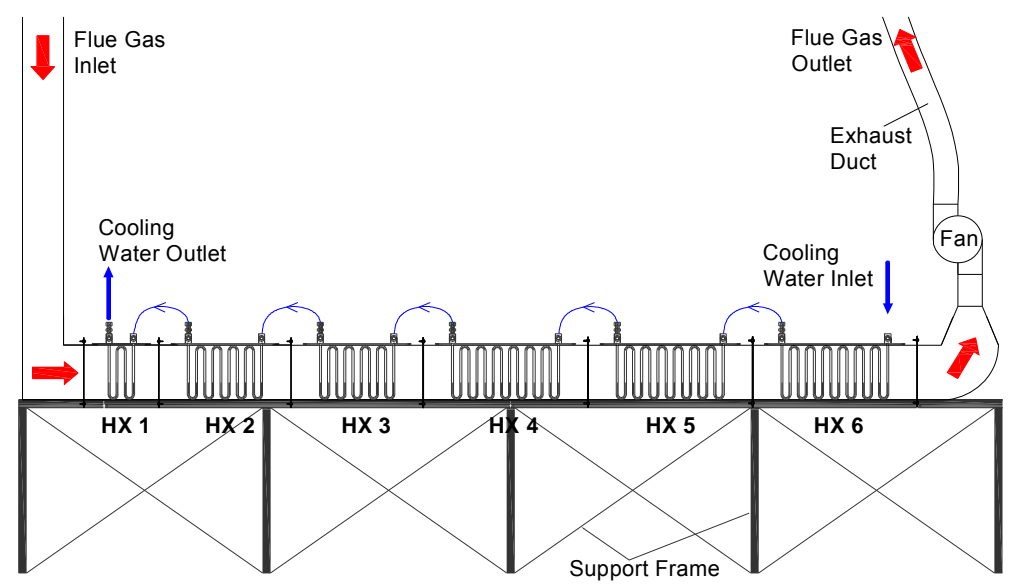

Figure 5-2: Sketch of Smooth Wall Tube Heat Exchanger Apparatus.

Figure 5-3 shows pilot scale data and results of theoretical predictions for a test at the coal-fired power plant, in which the water vapor condensation rates are compared for each heat exchanger. The data in Figure 5-3, for a $90.7^{\circ} \mathrm{F}$ inlet cooling water temperature and a cooling water flow rate of $1449.5 \mathrm{lb} / \mathrm{hr}$, show that water vapor condensation occurred within all five of the active heat exchangers. In contrast, Figure $5-4$ shows results for $87.8^{\circ} \mathrm{F}$ and $620 \mathrm{lb} / \mathrm{hr}$ inlet cooling water, where almost all of the water vapor condensation occurred within HX4, HX5 and HX6. Figures 5-5 and 5-6 compare the effects of inlet cooling water temperature $\left(77.4\right.$ and $\left.99.6^{\circ} \mathrm{F}\right)$, with relatively fixed values of flue gas and water flow rates on water vapor condensation patterns. As Figures 5-3 to 5-6 demonstrate, predictions using the theoretical model are in close agreement with the measured water vapor condensation rates within each individual heat exchanger.

Comparisons were also made between measured and predicted values of water vapor capture efficiency for the entire heat exchanger array. (Note: condensation efficiency or water vapor capture efficiency is defined here as the total flow rate of water vapor condensed within the heat exchangers divided by the flow rate of water vapor entering the heat exchanger system). Figure 5-7 shows total condensation efficiency as a function of inlet cooling water temperature, Figure 5-8 shows the effect of cooling water flow rate and Figures 5-9 and 5-10 show the effects of flue gas flow rate for inlet cooling water temperatures of 75.8 to $78^{\circ} \mathrm{F}$ and 99.6 to $100.5^{\circ} \mathrm{F}$. 


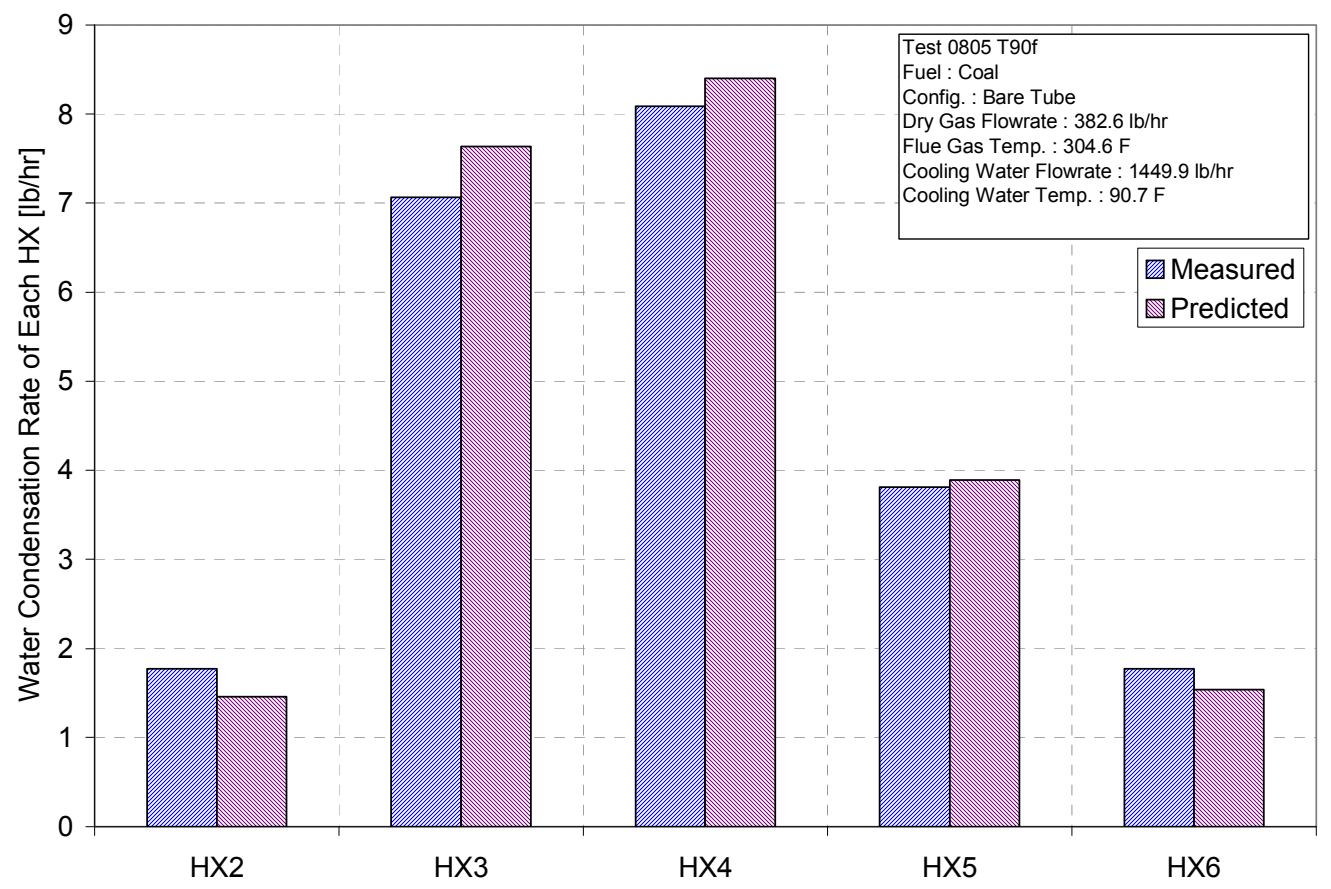

Figure 5-3: Comparison of Measure and Predicted Water Condensation Rates. Inlet Cooling Water at $90.7^{\circ} \mathrm{F}$ and $1450 \mathrm{lbm} / \mathrm{hr}$.

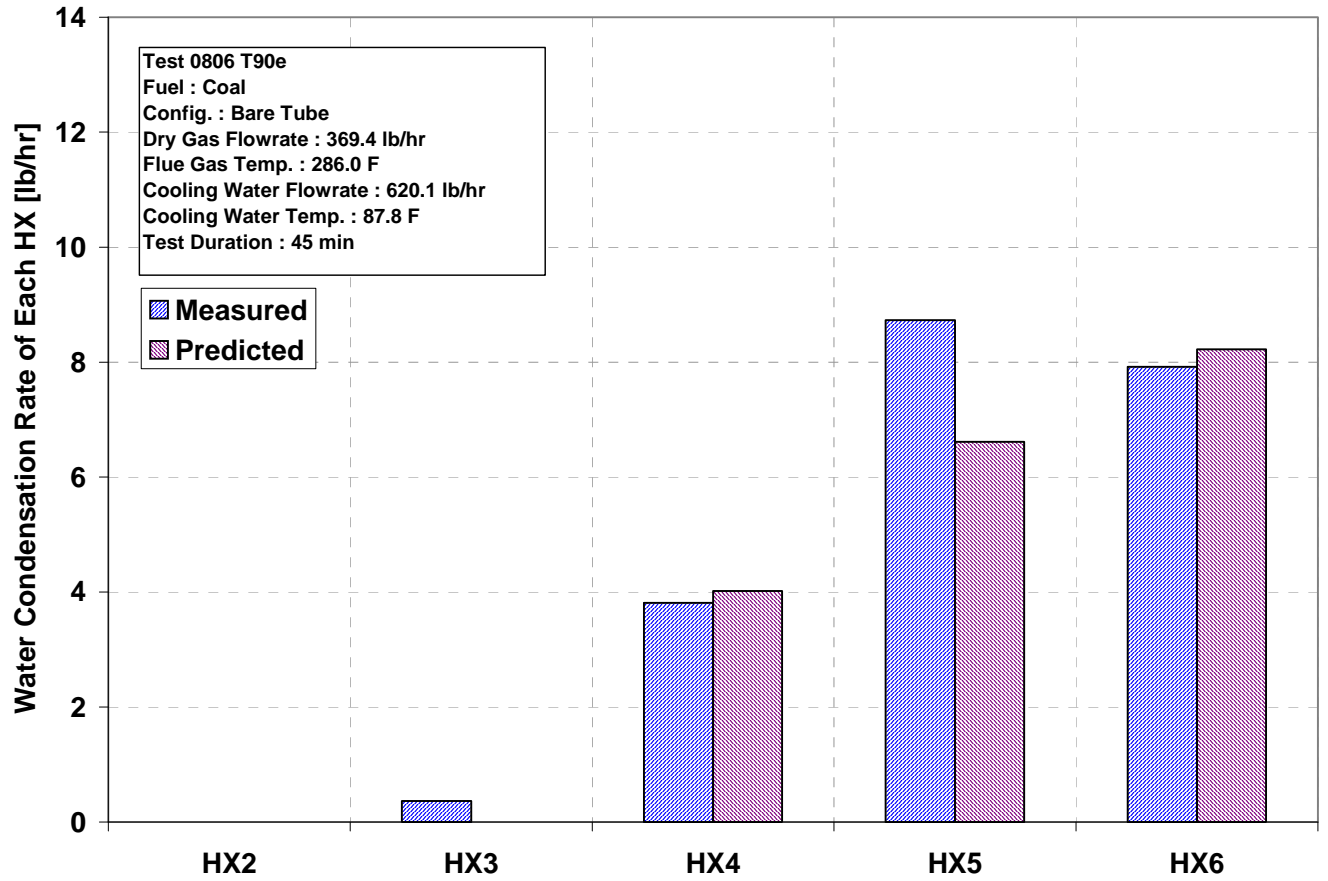

Figure 5-4: Inlet Cooling Water at $87.8^{\circ} \mathrm{F}$ and $620 \mathrm{lbm} / \mathrm{hr}$. Comparison of Measured and Predicted Water Condensation Rates. 


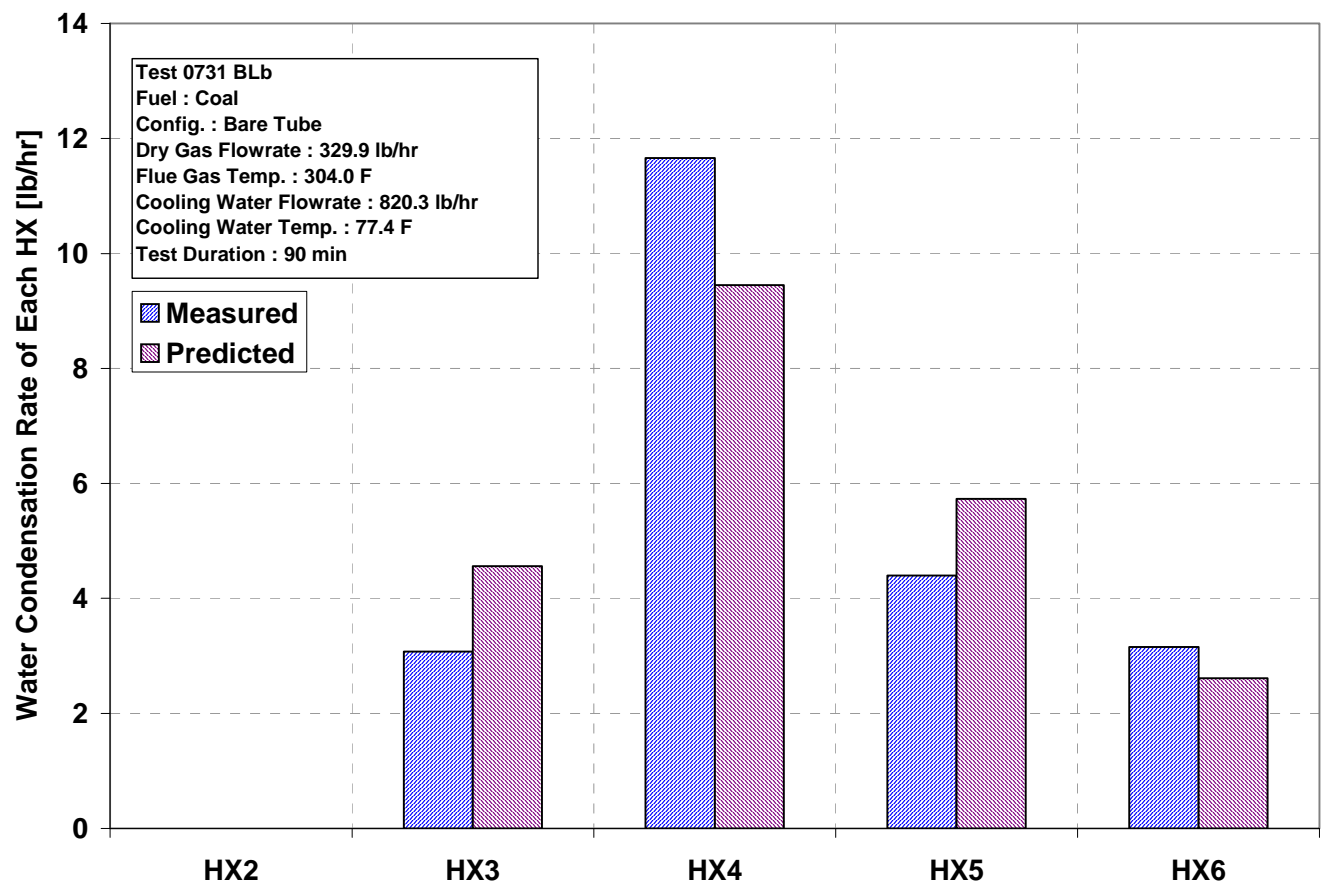

Figure 5-5: Inlet Cooling Water at $77.4^{\circ} \mathrm{F}$ and $820.3 \mathrm{lbm} / \mathrm{hr}$. Comparison of Measured and Predicted Water Condensation Rates.

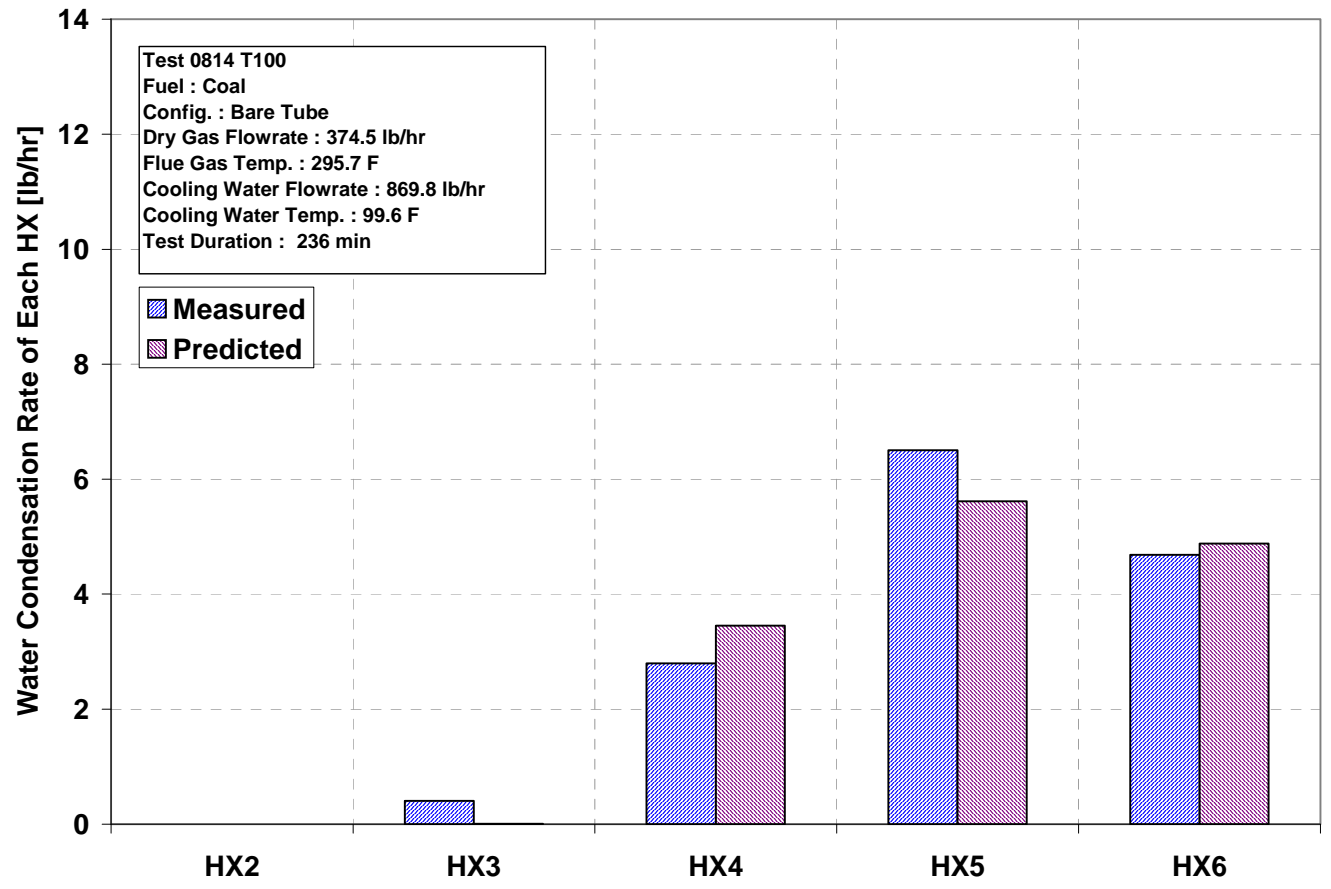

Figure 5-6: Inlet Cooling Water at $99.6^{\circ} \mathrm{F}$ and $869.8 \mathrm{lbm} / \mathrm{hr}$. Comparison of Measured and Predicted Water Condensation Rates. 


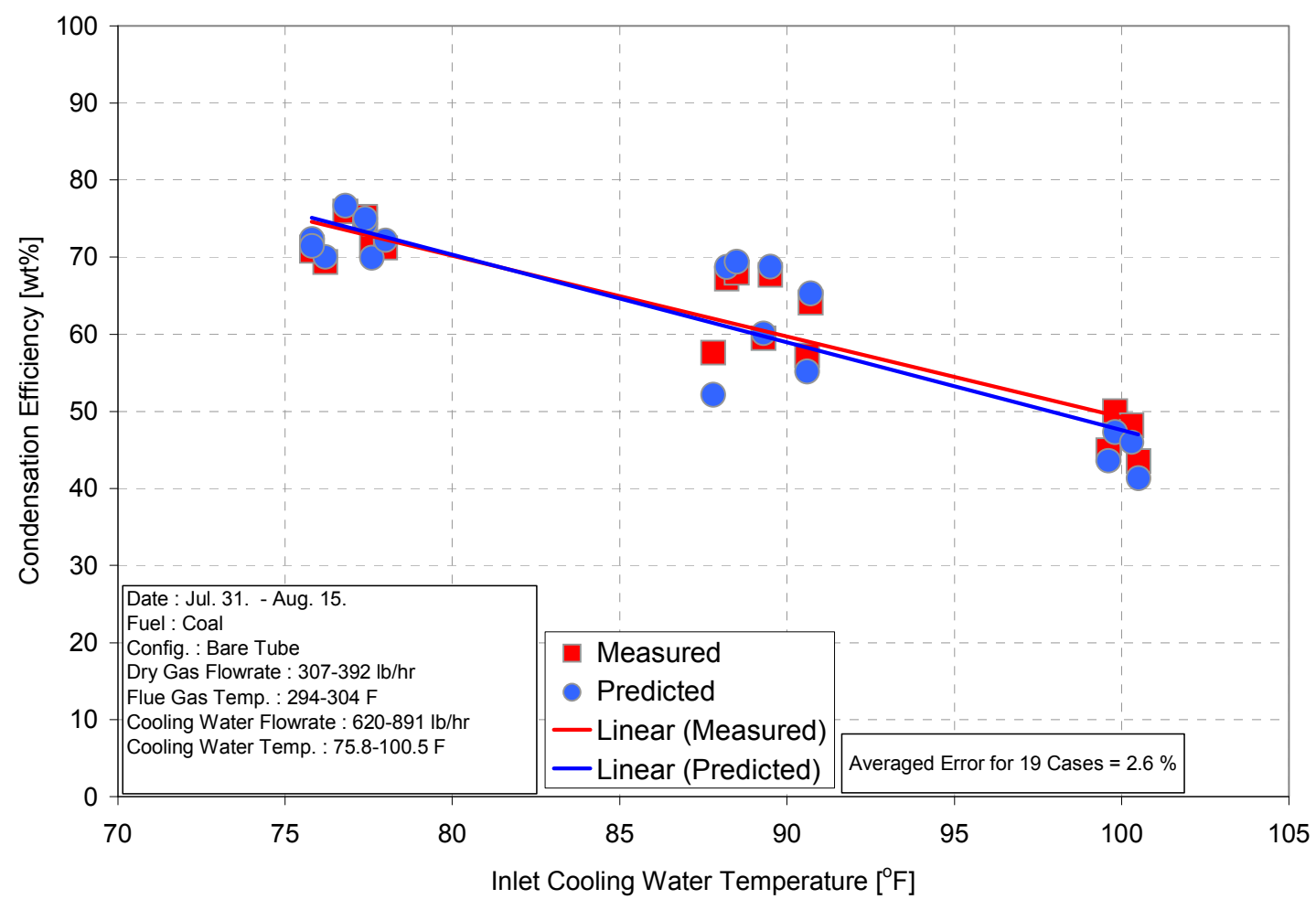

Figure 5-7: Variation of Water Vapor Condensation Efficiency with Inlet Cooling Water Temperature.

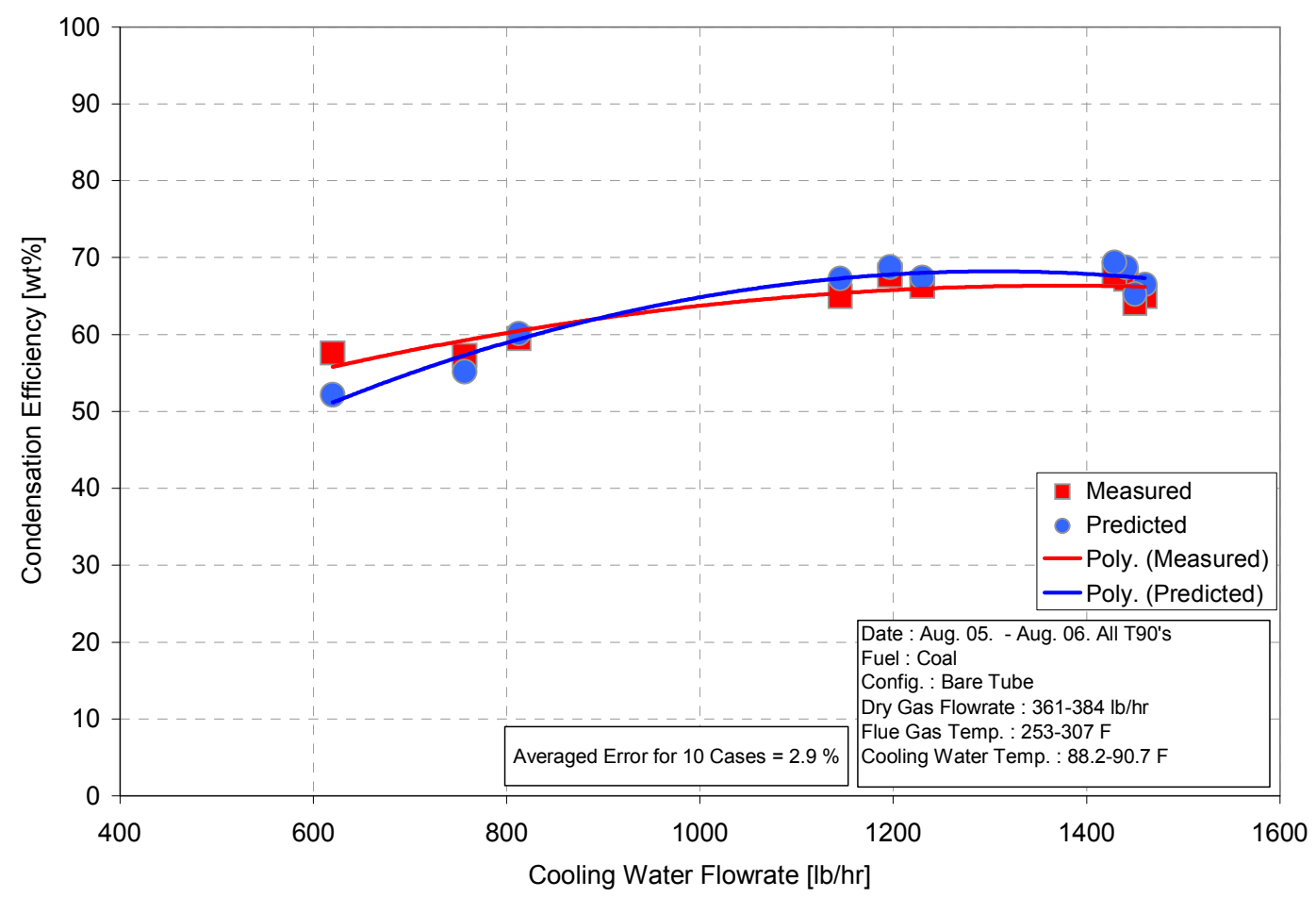

Figure 5-8: Variation of Water Vapor Condensation Efficiency with Cooling Water Flow Rate. 


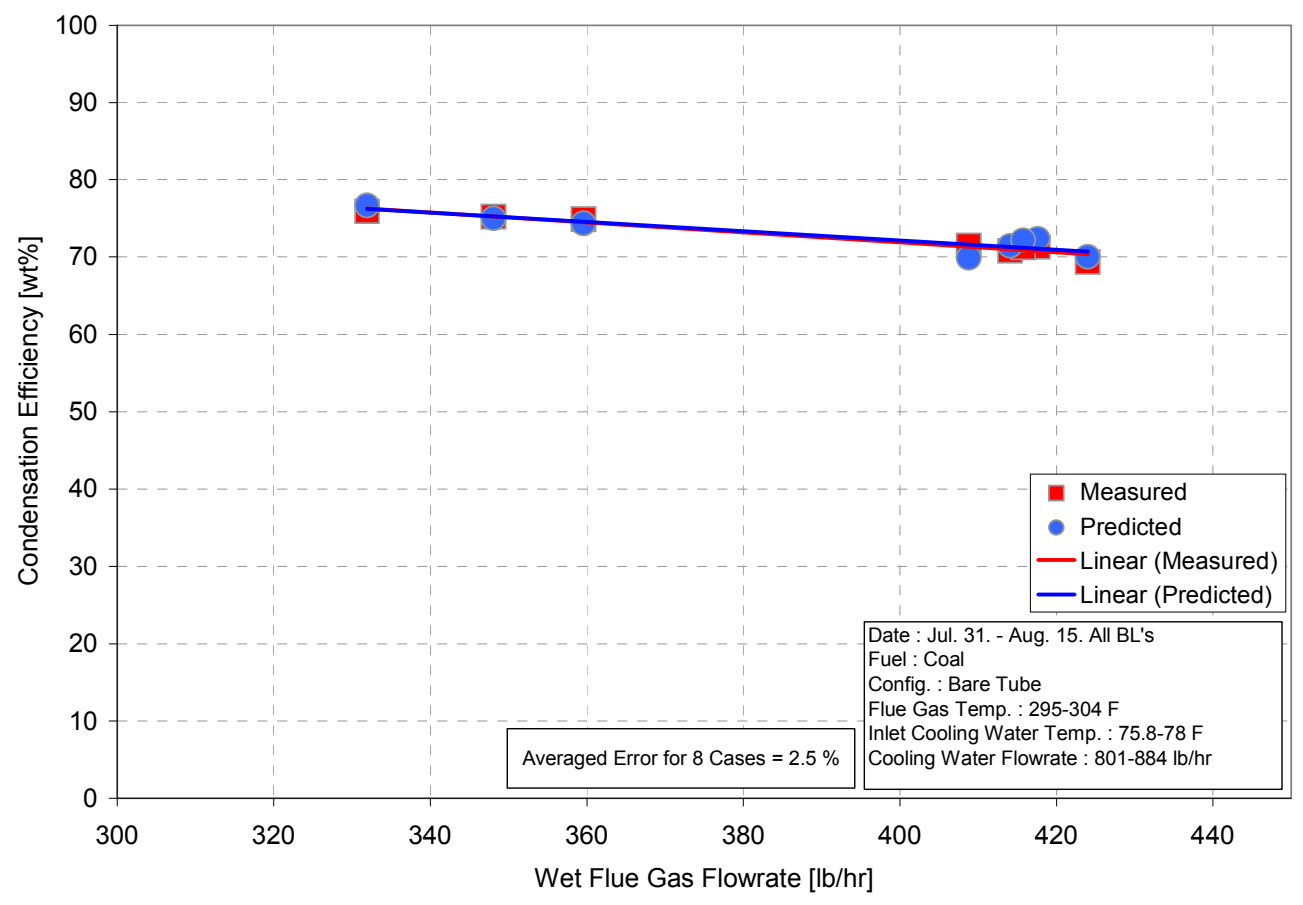

Figure 5-9: Variation of Water Vapor Condensation Efficiency with Flue Gas Flow Rate (Inlet Cooling Water at 75.8 to $78^{\circ} \mathrm{F}$.)

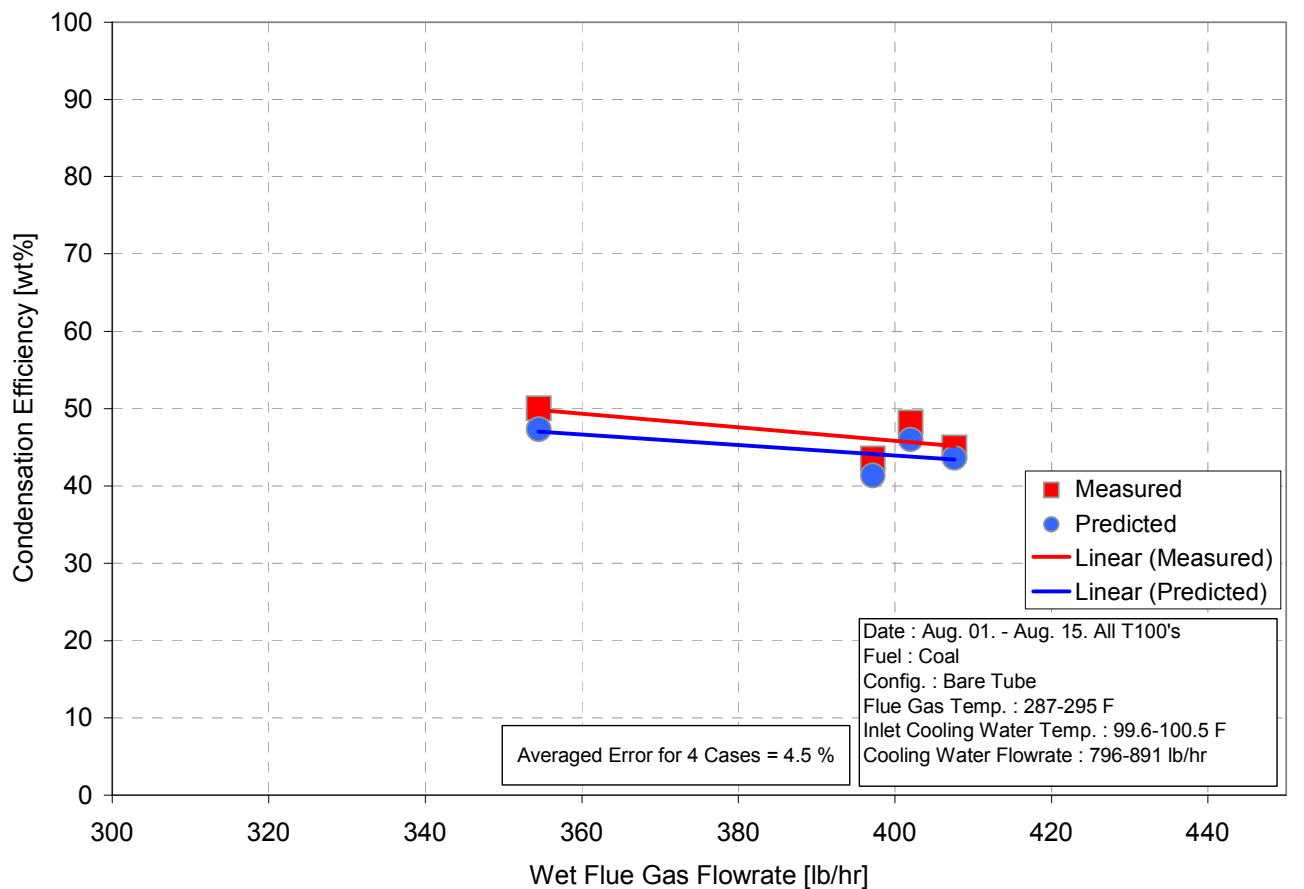

Figure 5-10: Variation of Water Vapor Condensation Rate with Flue Gas Flow Rate. (Inlet Cooling Water at $100^{\circ} \mathrm{F}$.) 
The results show that in most cases, the predictions agree with the measured values to within a few percent (Figure 5-11). Similar predictions were made for test conditions involving condensation of water vapor from flue gas from oil and natural gasfired boilers, with very close agreement obtained between the measured and predicted values (Figures 5-12 and 5-13). These results confirm the accuracy of the theoretical heat and mass transfer model and provide confidence in use of the model as a tool for designing full scale heat exchangers for power plant applications.

The results described above for high moisture coal illustrate a strong dependence of condensation efficiency on inlet cooling water temperature (from 48 percent at $100^{\circ} \mathrm{F}$ to 74 percent at $77^{\circ} \mathrm{F}$ ), a strong dependence on cooling water flow rate (from 57 percent at $600 \mathrm{lb} / \mathrm{hr}$ and $90^{\circ} \mathrm{F}$ to 67 percent at $1400 \mathrm{lb} / \mathrm{hr}$ and $90^{\circ} \mathrm{F}$ ) and a weaker dependence on flue gas flow rate (from 77 percent at $330 \mathrm{lb} / \mathrm{hr}$ and $77^{\circ} \mathrm{F}$ to 70 percent at $420 \mathrm{lb} / \mathrm{hr}$ and $77^{\circ} \mathrm{F}$ ). While the design of the heat exchanger system tested here is not optimized, the results suggest that water capture efficiencies greater than 70 percent will be possible for some process conditions. However, for other combinations of process conditions, much lower water capture efficiencies are to be expected. This is illustrated in Figure 5-14, which shows water capture efficiency versus the ratio of cooling water to flue gas flow rates. These results show that predicted capture efficiency decreases steadily with a decrease in $\mathrm{m}_{\mathrm{cw}} / \mathrm{m}_{\mathrm{fg}}$ and efficiencies from 10 to 30 percent will occur for values of $0.5<\mathrm{m}_{\mathrm{cw}} / \mathrm{m}_{\mathrm{fg}}<1.0$. 


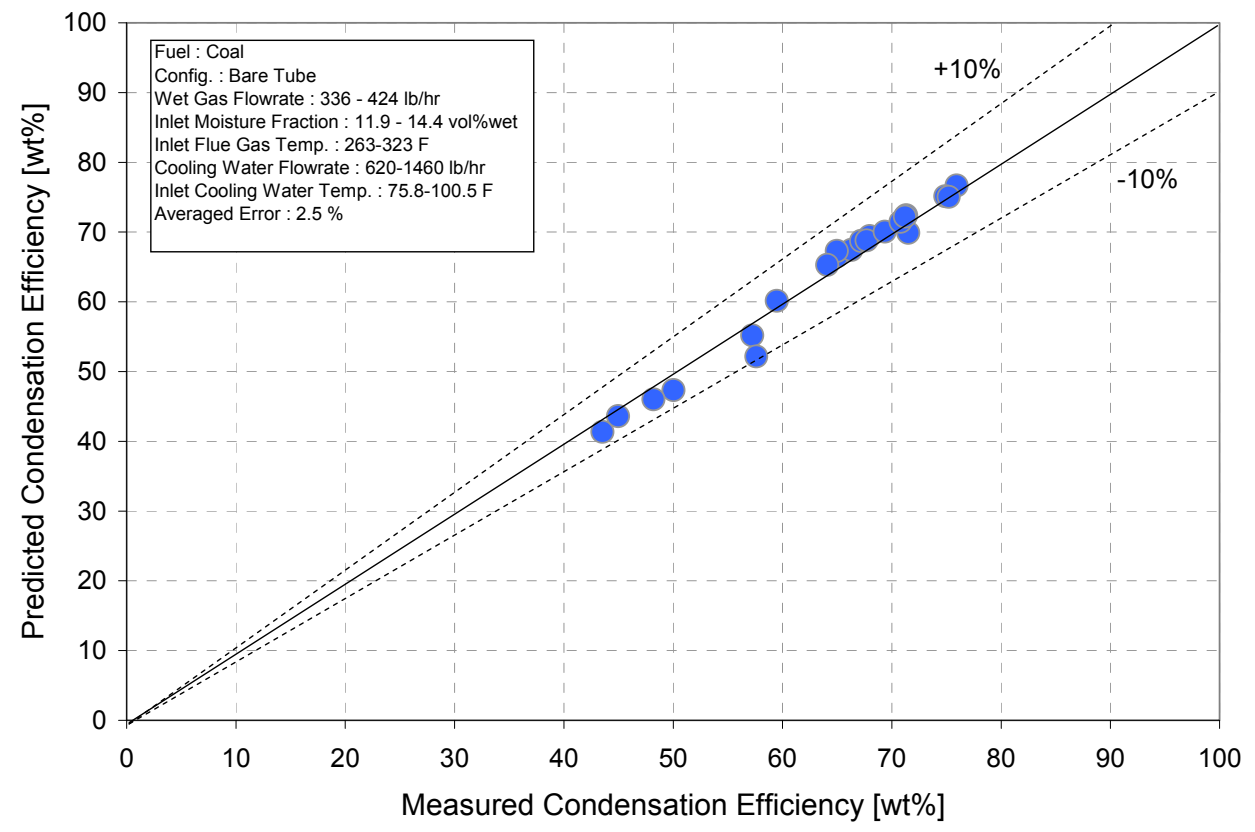

Figure 5-11: Predicted and Measured Condensation Efficiency: Coal-Fired Test Data.

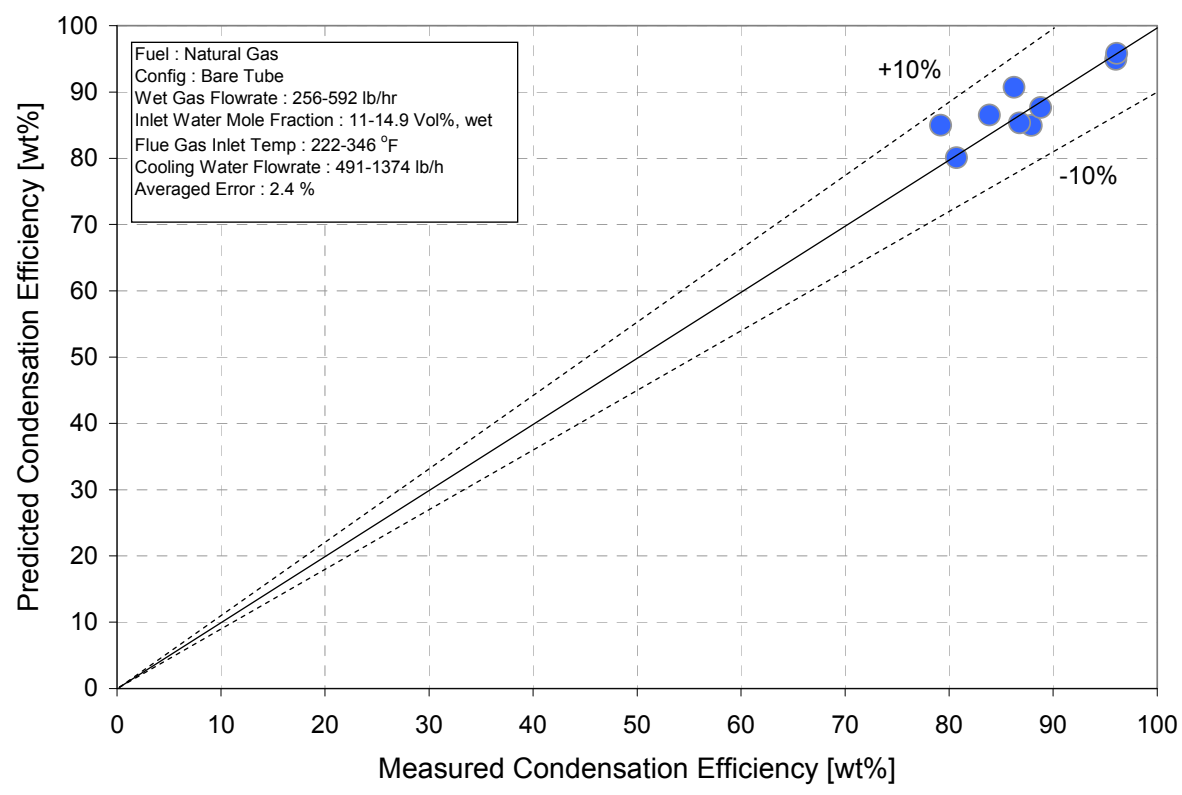

Figure 5-12: Predicted and Measured Condensation Efficiency: Natural Gas-Fired Test Data. 


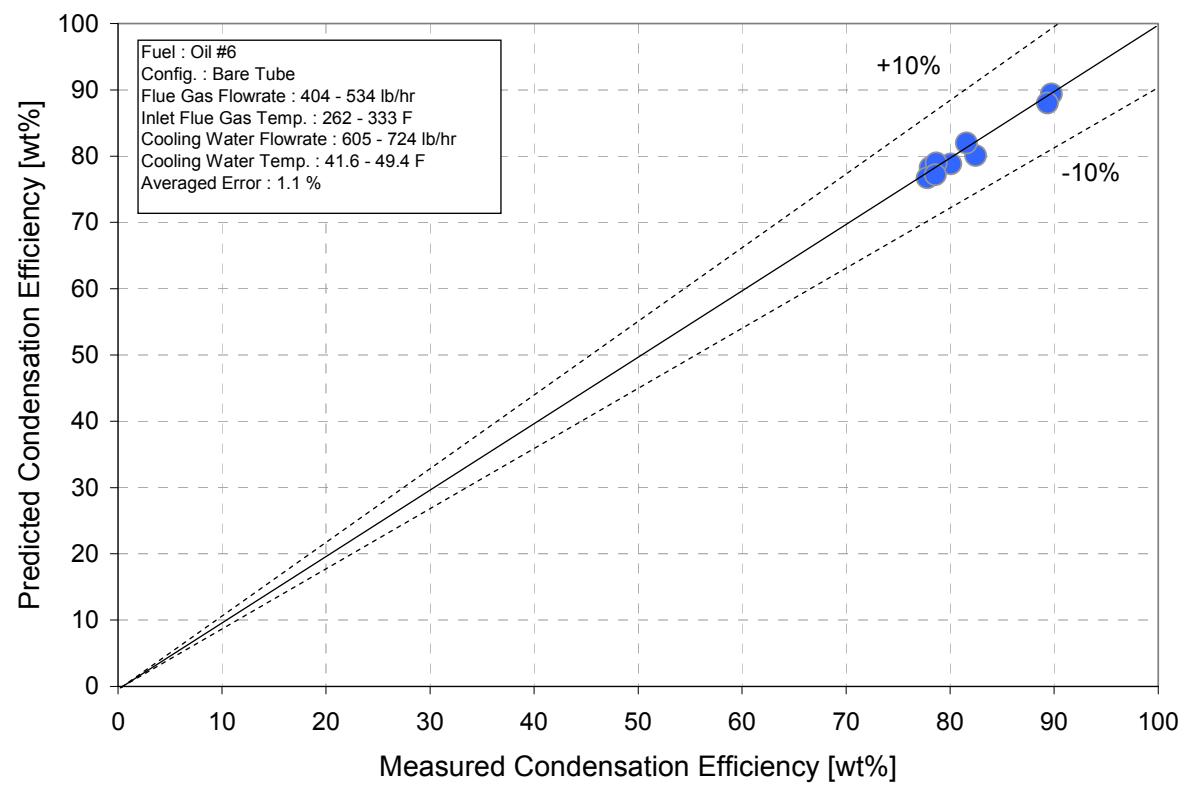

Figure 5-13: Predicted and Measured Condensation Efficiency: Oil-Fired Test Data

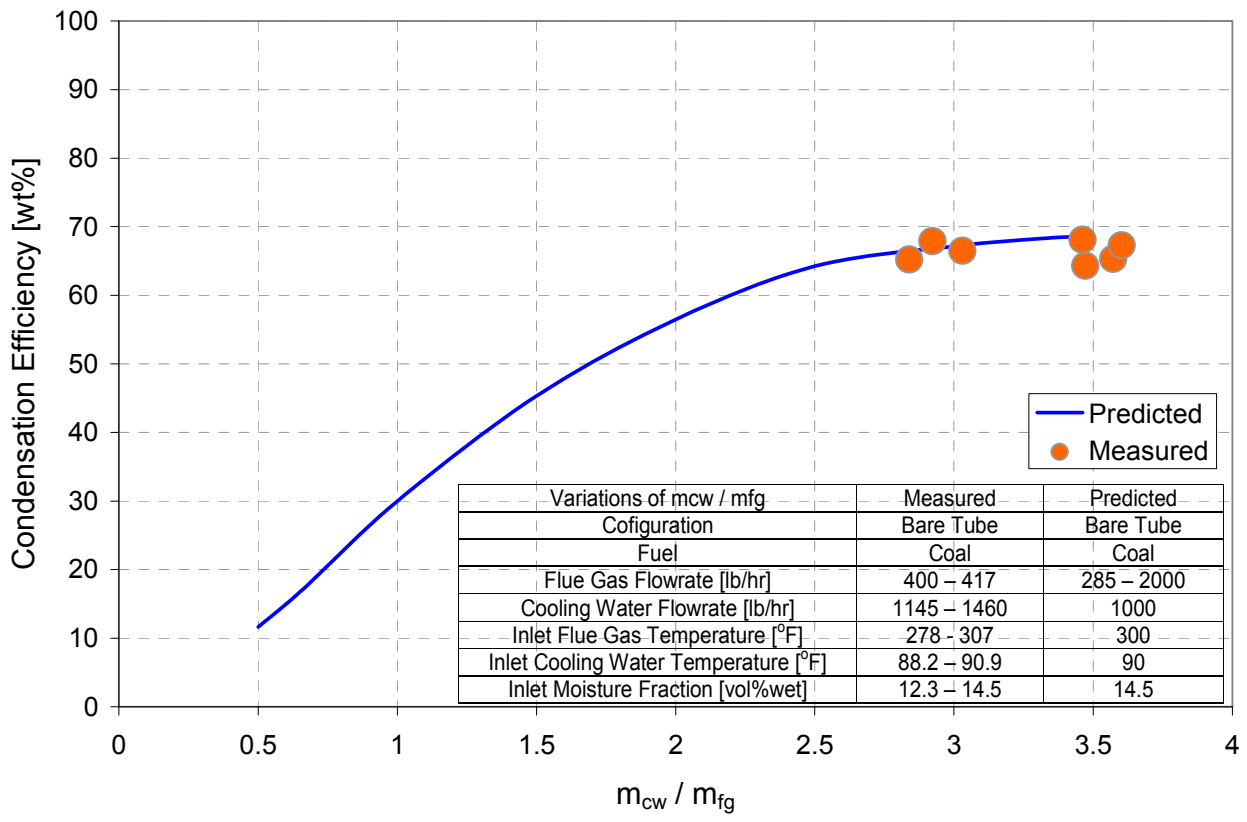

Figure 5-14: Effect of Flow Rate Ratio of Cooling Water to Flue Gas on Water Vapor Condensation Efficiency for $0.5<\mathrm{m}_{\mathrm{cw}} / \mathrm{m}_{\mathrm{fg}}<3.5$. 


\section{CHAPTER 6}

\section{ESTIMATES OF MAXIMUM RECOVERABLE \\ FLUE GAS MOISTURE AND POTENTIAL HEAT RATE IMPROVEMENTS}

\section{INTRODUCTION}

The experimental results on rates of heat transfer and water vapor condensation presented in Chapter 3 of this report were obtained with shell and tube type heat exchangers in which the sensible and latent heat of the flue gas was transferred to cooling water. The measured percentage of flue gas moisture which condensed varied with parameters such as inlet moisture concentration, inlet cooling water and flue gas temperatures, cooling water and flue gas flow rates and heat exchanger design. For the conditions at which the experiments were performed, the captured flue gas moisture ranged from 48 to $87 \%$ of the inlet flue gas moisture content.

This section of the report describes analyses to determine the maximum possible recoverable flue gas moisture and the expected magnitudes of heat rate improvement. Different process arrangements are possible, depending on the application. For power plants with cold side ESP's or baghouses for particulate control, but without wet flue gas scrubbers (FGD), the heat exchangers would be located between the cold side ESP or baghouse and the stack. For power plants with FGD's, one heat exchanger could be located between the ESP and FGD and additional heat exchangers could be located between the FGD and stack (see Figure 6-1). 

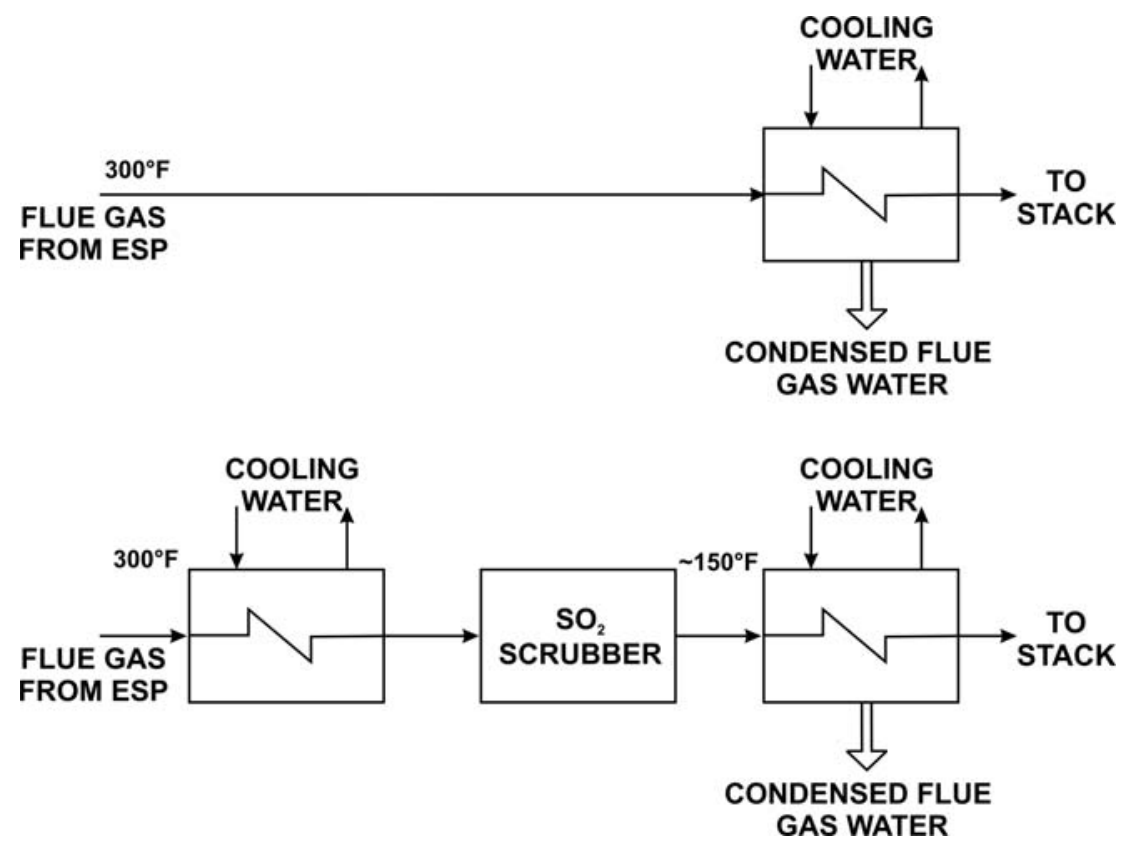

Figure 6-1: Potential Locations of Flue Gas Heat Exchangers for Coal-Fired Units With and Without $\mathrm{SO}_{2}$ Scrubbers.

The analyses described in this Chapter consider a power plant with a cold side ESP, but without an FGD. It is assumed that availability of water for flue gas cooling will be limited to cold boiler feedwater taken from the discharge of the main steam condenser, with additional cooling occurring by rejecting heat to inlet combustion air and ambient air. The resulting heat exchangers are arranged in series into three separate groups as follows (Figure 6-2):

- Group I: Heat exchangers using cold boiler feedwater as the heat sink, with the feedwater taken from the discharge of the main steam condenser. The Group I heat exchangers are also referred to as FG-FWH in this report.

- Group II: Heat exchangers using cold combustion air as the heat sink, with the combustion air taken from the outlet of the forced draft (FD) fan. The Group II heat exchangers are also referred to as FG-AHX1 in this report.

- Group III: Heat exchangers using ambient air as the heat sink. These heat exchangers are similar in concept to those used for dry cooling of steam power plants. The Group III heat exchangers are also referred to as FG-AHX2 in this report. 
Analyses of the three groups of heat exchangers are described in the following sections of this Chapter, with the analyses for the Group I heat exchangers described first.

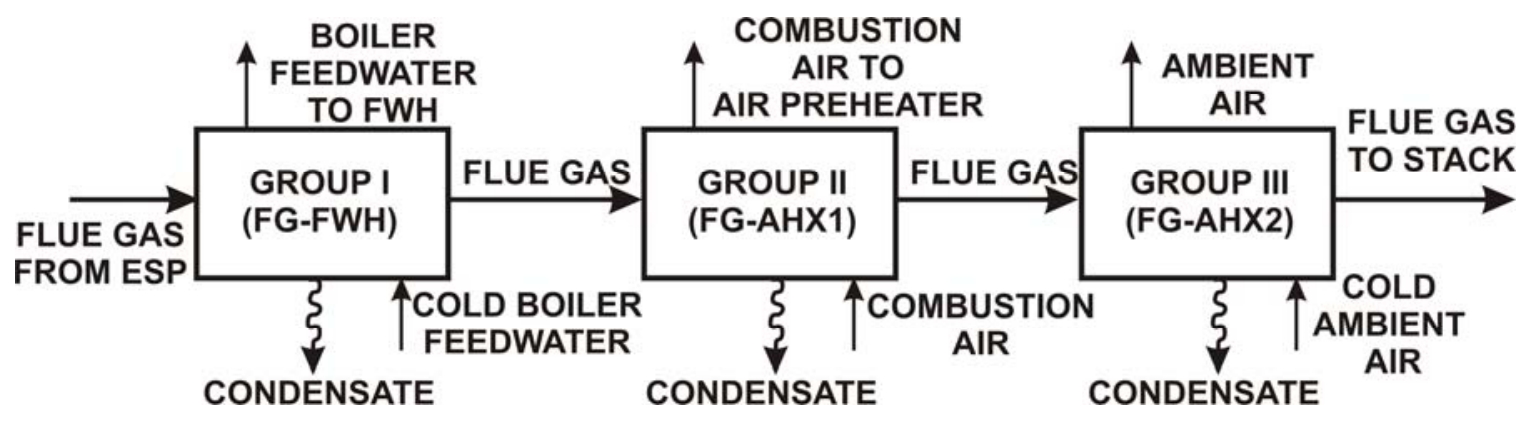

Figure 6-2: Flue Gas Cooling Process with Three Groups of Heat Exchangers.

\section{GROUP I HEAT EXCHANGERS: COLD BOILER FEEDWATER AS HEAT SINK}

\section{Introduction}

Under the right conditions, sensible and latent heat transferred from flue gas can be used to preheat boiler feedwater, thus reducing the steam turbine extraction flow rates to the feedwater heaters and thereby reducing unit heat rate. The potential magnitude of the heat rate impact and water capture efficiency of the Group I heat exchangers is illustrated in the analyses described in this section, one of which is for a supercritical steam cycle and the other for a subcritical steam cycle.

\section{Supercritical Steam Turbine Cycle with FG-FWH Heat Recovery}

Figure 6-3 is the diagram of the steam turbine cycle for a $585 \mathrm{MW}$ supercritical coal-fired unit. There are seven feedwater heaters, each using turbine extraction steam to preheat the feedwater. For the conditions shown here, the feedwater enters the first feedwater heater at $87.1^{\circ} \mathrm{F}$ and is raised in temperature to $151.9^{\circ} \mathrm{F}$ by extraction stream $G$ from the low pressure turbine (Figure 6-4). Similar processes in the other six feedwater heaters result in a feedwater temperature of $506.9^{\circ} \mathrm{F}$ at the economizer inlet. 


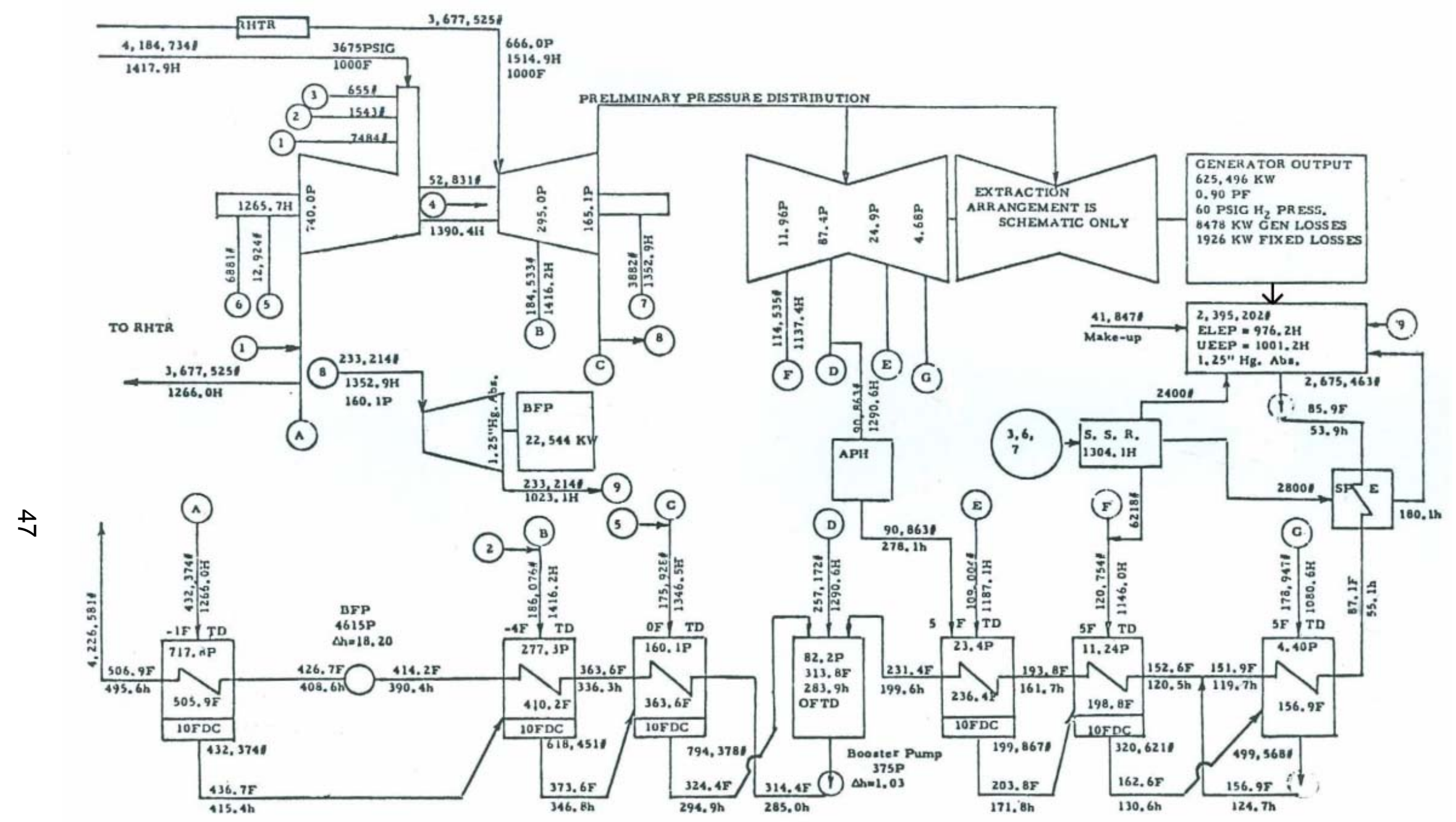

Figure 6-3: Steam Turbine Cycle Diagram for Supercritical Unit. 


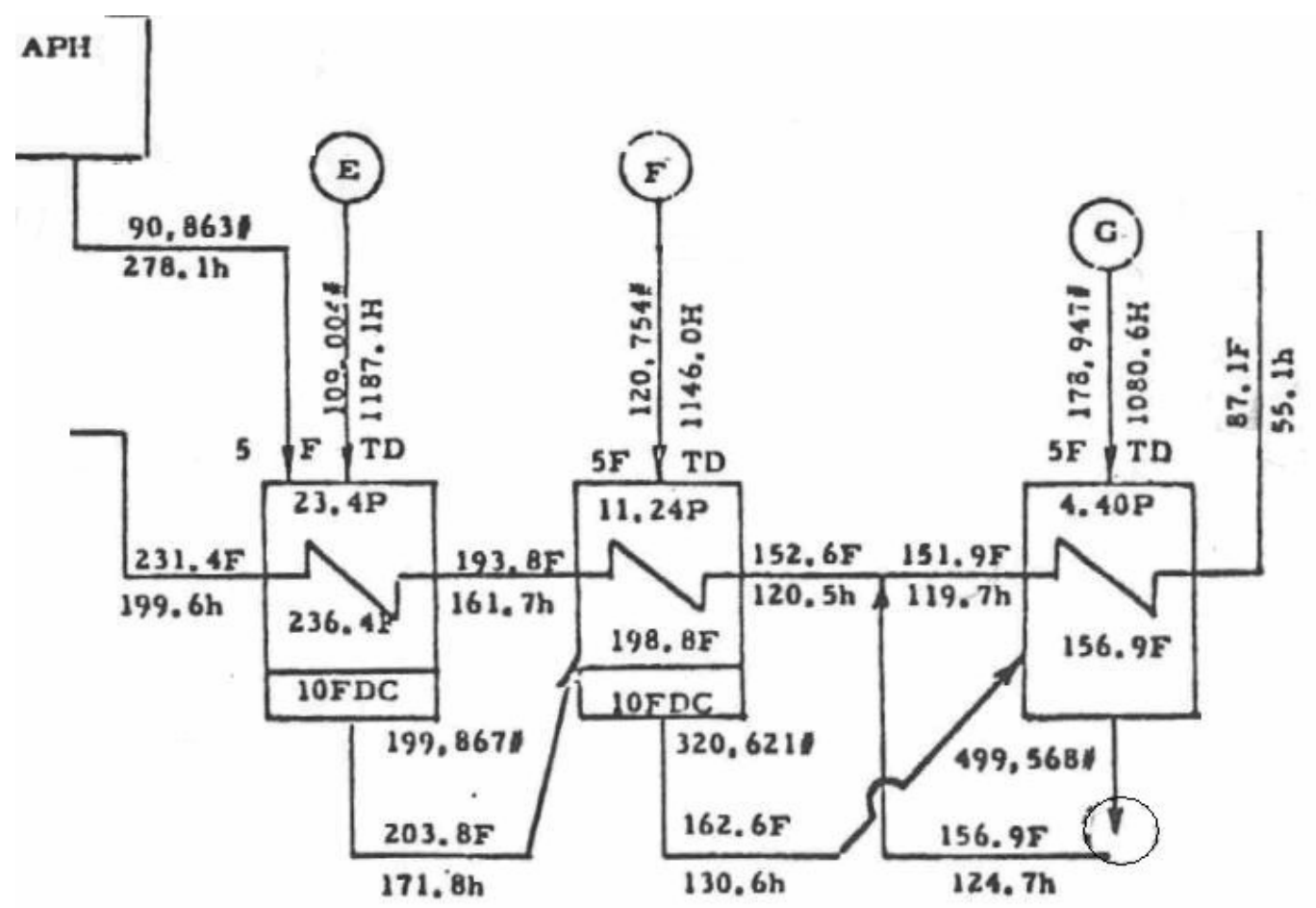

Figure 6-4: Detailed View of Feedwater Heaters 1 to 3 with Extraction Flows G to E.

The Group I heat exchangers (FG-FWH) use sensible and latent heat transferred from the flue gas to partially preheat the cycle feedwater. For purposes of the analysis, the flue gas entering FG-FWH is assumed to be at $300^{\circ} \mathrm{F}$, which is a typical ESP gas exit temperature and the cold feedwater entering FG-FWH is assumed to be at the inlet temperature to the first feedwater heater. (This is $87.1^{\circ} \mathrm{F}$ in the calculation based on the cycle shown in Figure 6-3.)

The FG-FWH heat exchanger system can be thought of as having two stages: (1) a high temperature stage, extending from the ESP exit to the onset of flue gas water vapor condensation, for transfer of sensible heat from the flue gas to the boiler feedwater and (2) a low temperature stage for transfer of mostly latent heat, released during flue gas water vapor condensation, to the feedwater. The amount of sensible heat transferred from the flue gas to the feedwater can be approximated by

$$
Q_{s}=m_{g} \times C p_{g} \times\left(T g_{\text {in }}-T_{\text {dew }}\right)
$$


and the increase in feedwater temperature due to sensible heat addition is

$$
\left(\Delta T_{f w}\right)_{s}=Q_{s} /\left(m_{f w} \times C_{w}\right)
$$

For coals illustrated in this report and for inlet feedwater flow rates typical of steam cycles used in coal-fired power plants, the analyses performed in this study show that $\left(\Delta \mathrm{T}_{\mathrm{fw}}\right)_{\mathrm{s}} \sim 85^{\circ} \mathrm{F}$.

Captured latent heat also causes an increase in feedwater temperature, but the exit feedwater temperature from this stage must be less than the flue gas moisture dew point. Assuming, for example, an inlet feedwater temperature of $87.1^{\circ} \mathrm{F}$ and a flue gas water vapor dewpoint of $130^{\circ} \mathrm{F}$, the maximum feedwater temperature increase due to latent heat capture would be $\left(\Delta \mathrm{T}_{\mathrm{fw}}\right)_{\mathrm{L}} \sim 43^{\circ} \mathrm{F}$.

The total increase in feedwater temperature is

$$
\left(\Delta \mathrm{T}_{\mathrm{fw}}\right) \mathrm{s}+\left(\Delta \mathrm{T}_{\mathrm{fw}}\right) \mathrm{L}
$$

the maximum rate of latent heat transfer to the feedwater is

$$
Q_{L}=m_{f w} \times C_{w}\left(T_{d e w}-T_{f w i n}\right)
$$

and the maximum rate of water vapor condensation which can be converted into a heat rate improvement is

$$
M c=Q_{L} / h_{f g} .
$$

The amount of latent heat which can be utilized in this process is thus constrained by feedwater flow rate $\left(\mathrm{m}_{\mathrm{fw}}\right)$ and the dew point temperature of the water vapor in the flue gas $\left(T_{\text {dew }}\right)$. For flue gas from a high moisture lignite, the dew point is in the 125 to $133^{\circ} \mathrm{F}$ range, with dew points having lower temperatures for flue gas with lower moisture concentrations. 
As will be shown by the calculations in this report, all of the sensible heat, but only a small part of the captured latent heat can be utilized for preheating feedwater. Additional heat sinks would be needed to maximize the overall amount of flue gas moisture which can be condensed.

\section{Analysis of Flue Gas Feedwater Heater: (Group I Heat Exchangers)}

By using thermal energy from flue gas to preheat the feedwater, the required flow rates of the various low temperature turbine steam extraction streams can be reduced or eliminated. The objective of this part of the analysis is to determine what reductions would occur in the various extraction streams, while maintaining the exit temperature from the third feedwater heater at $231.4^{\circ} \mathrm{F}$, which is the value from the original cycle design (See Figure 6-5).

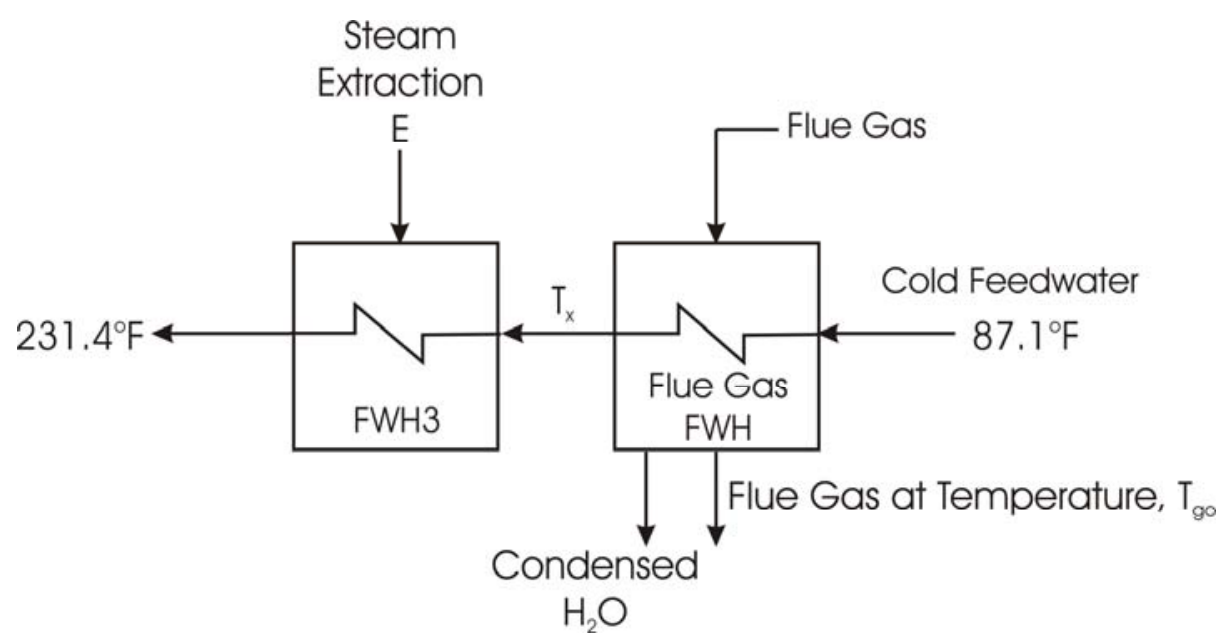

Figure 6-5: Flue Gas Feedwater Heat Exchanger.

Analyses were performed for four coals (lignite, subbituminous and bituminous), all in a boiler operating with $21 \%$ excess air and with a $300^{\circ} \mathrm{F}$ air preheater gas exit temperature. Table 6-1 gives the coal analysis and volumetric flue gas composition for each.

Using the properties of each flue gas, ASPEN Plus was used to simulate the FGFWH heat exchange process shown in Figure 6-5. These results, listed in Table 6-2, show that coal type has a strong effect on the feedwater temperature at the exit of the 
flue gas heat exchanger, $T_{x}$, and on the flue gas water vapor condensation rate. The calculations, performed for both typical summer and winter conditions, show a small effect of season of the year on rate of water recovery. The seasonal effect with FG$\mathrm{FWH}$ heat exchangers is due to seasonal variations in flue gas moisture concentration due to variations in amount of water vapor carried into the boiler with combustion air.

Table 6-1: As-Received Coal Properties and Flue Gas Composition

\begin{tabular}{|ccccc|}
\hline & Lignite & $\begin{array}{c}\text { Beulah-Zap } \\
\text { Ultimate Analyses (wt\%) }\end{array}$ & $\begin{array}{c}\text { PRB } \\
\text { Moisture }\end{array}$ & \multicolumn{4}{c|}{ Illinois \#6 } \\
\cline { 2 - 5 } Carbon & 34.50 & 32.24 & 28.09 & 7.97 \\
Hydrogen & 2.97 & 44.62 & 49.21 & 60.42 \\
Nitrogen & 0.72 & 2.95 & 3.51 & 3.89 \\
Chlorine & 0.00 & 0.70 & 0.73 & 1.07 \\
Sulfur & 0.51 & 0.54 & 0.02 & 0.05 \\
Ash & 12.30 & 6.59 & 0.45 & 4.45 \\
Oxygen & 10.97 & 12.32 & 6.31 & 11.67 \\
\multicolumn{5}{c}{ Flue Gas Compositions (volume $\%)$} \\
$\mathrm{H}_{2} \mathrm{O}$ & $16.37 \%$ & $12.23 \%$ & $11.14 \%$ & $6.60 \%$ \\
$\mathrm{~N}_{2}$ & $67.36 \%$ & $70.24 \%$ & $71.39 \%$ & $75.05 \%$ \\
$\mathrm{O}_{2}$ & $3.10 \%$ & $3.24 \%$ & $3.30 \%$ & $3.46 \%$ \\
$\mathrm{CO}_{2}$ & $12.81 \%$ & $13.93 \%$ & $13.78 \%$ & $13.81 \%$ \\
Other & $0.35 \%$ & $0.36 \%$ & $0.39 \%$ & $1.08 \%$ \\
\hline \multicolumn{5}{c}{}
\end{tabular}

Table 6-2: Effect of Coal Type on Performance of Flue Gas Feedwater Heater: Supercritical FG-FWH ASPEN Calculations with $\varepsilon=0.85$.

\begin{tabular}{|c|c|c|c|c|c|c|c|c|}
\hline & \multicolumn{2}{|c|}{ LIGNITE } & \multicolumn{2}{|c|}{ Beulah-Zap } & \multicolumn{2}{|c|}{ PRB } & \multicolumn{2}{|c|}{ Illinois \#6 } \\
\hline & Summer & Winter & Summer & Winter & Summer & Winter & Summer & Winter \\
\hline Boiler $\eta$ : & $83.29 \%$ & $82.16 \%$ & $85.12 \%$ & $83.98 \%$ & $86.01 \%$ & $84.91 \%$ & $89.94 \%$ & $88.96 \%$ \\
\hline Flue Gas Flow Rate [lb/hr]: & $6,194,672$ & $6,224,641$ & $6,412,514$ & $6,441,210$ & $6,266,221$ & $6,289,659$ & $5,674,773$ & $5,683,582$ \\
\hline Flue Gas Flow Rate [mol/hr]: & 217,969 & 217,883 & 221,496 & 221,246 & 215,892 & 215,466 & 191,929 & 191,046 \\
\hline Flue Gas Moisture Flow Rate [mol/hr]: & 36,157 & 33,539 & 28,551 & 25,651 & 25,754 & 22,837 & 15,190 & 12,335 \\
\hline Flue Gas Moisture Fraction [vol \%]: & $16.59 \%$ & $15.39 \%$ & $12.89 \%$ & $11.59 \%$ & $11.93 \%$ & $10.60 \%$ & $7.91 \%$ & $6.46 \%$ \\
\hline Flue Gas Dew Point $\left[{ }^{\circ} \mathrm{F}\right]:$ & 133.5 & 130.6 & 124.1 & 120.2 & 121.2 & 117.0 & 106.8 & 100.0 \\
\hline Flue Gas Exit Temperature, $\mathrm{T}_{\mathrm{go}}\left[{ }^{\circ} \mathrm{F}\right]$ : & 129.9 & 127.2 & 121.2 & 117.7 & 118.5 & 114.8 & 106.1 & 107.4 \\
\hline Flue Gas Moisture Capture Efficiency: & $10.24 \%$ & $9.85 \%$ & $8.14 \%$ & $7.00 \%$ & $7.68 \%$ & $6.18 \%$ & $1.93 \%$ & $0.00 \%$ \\
\hline Feedwater Exit Temp, $\mathrm{T}_{\mathrm{x}}\left[{ }^{\circ} \mathrm{F}\right]$ : & 203.5 & 202.5 & 201.2 & 199.6 & 198.1 & 196.3 & 183.4 & 180.2 \\
\hline FWH $\varepsilon:$ & 0.850 & 0.850 & 0.850 & 0.850 & 0.850 & 0.850 & 0.850 & 0.850 \\
\hline Feedwater Flow Rate thru FWH [lb/hr]: & $3,006,075$ & $3,002,826$ & $2,999,086$ & $2,994,504$ & $2,990,061$ & $2,984,824$ & $2,946,075$ & $2,936,614$ \\
\hline Total Water captured [lb/hr]: & 66,714 & 59,497 & 41,845 & 32,348 & 35,627 & 25,443 & 5,270 & 0 \\
\hline
\end{tabular}


The results shown in Table 6-2 were carried out for a FG-FWH heat exchanger effectiveness of 0.85 . (Please see Appendix A for definition of heat exchanger effectiveness). The heat transfer and mass diffusion model described in Chapter 5 was used to determine the effect of heat transfer surface area on heat exchanger effectiveness for process conditions similar to those described here. The results of that analysis (Figure 6-6) show that a heat exchanger surface area 2.5 times as large would result in an increase in heat exchanger effectiveness from 0.85 to approximately 0.98 . Additional analyses were then performed to determine the effect of increasing the effectiveness from 0.85 to 1.00 on rates of water recovery from flue gas for the four coals. The results, summarized in Tables 6-2 and 6-3 and Figure 6-7, show a strong effect of heat exchanger effectiveness on water capture efficiency. For example for the case of a PRB coal, by using the larger heat exchanger, the water capture efficiency would go from approximately 8 to 18 percent.

Table 6-3: Supercritical FG-FWH ASPEN Calculations with $\varepsilon=1.00$

\begin{tabular}{|c|c|c|c|c|c|c|c|c|}
\hline & \multicolumn{2}{|c|}{ LIGNITE } & \multicolumn{2}{|c|}{ Beulah-Zap } & \multicolumn{2}{|c|}{ PRB } & \multicolumn{2}{|c|}{ Illinois \#6 } \\
\hline & Summer & Winter & Summer & Winter & Summer & Winter & Summer & Winter \\
\hline Boiler $n$ & $83.29 \%$ & $82.16 \%$ & $85.12 \%$ & $83.98 \%$ & $86.01 \%$ & $84.91 \%$ & $89.94 \%$ & $88.96 \%$ \\
\hline Flue Gas Flow Rate [lb/hr]: & $6,194,672$ & $6,224,641$ & $6,412,514$ & $6,441,210$ & $6,266,221$ & $6,289,659$ & $5,674,949$ & $5,683,582$ \\
\hline Flue Gas Flow Rate [mol/hr]: & 217,969 & 217,883 & 221,496 & 221,246 & 215,892 & 215,466 & 191,935 & 191,046 \\
\hline Flue Gas Moisture Flow Rate [mol/hr]: & 36,157 & 33,539 & 28,551 & $25,651.2$ & 25,754 & 22,837 & 15,190 & 12,335 \\
\hline Flue Gas Moisture Fraction [vol \%]: & $16.59 \%$ & $15.39 \%$ & $12.89 \%$ & $11.59 \%$ & $11.93 \%$ & $10.60 \%$ & $7.91 \%$ & $6.46 \%$ \\
\hline Flue Gas Dew Point $\left[{ }^{\circ} \mathrm{F}\right]:$ & 133.5 & 130.6 & 124.1 & 120.2 & 121.2 & 117.0 & 117.0 & 106.8 \\
\hline Flue Gas Exit Temperature $\left[{ }^{\circ} \mathrm{F}\right]:$ & 126.5 & 123.7 & 117.2 & 113.5 & 114.4 & 110.4 & 100.7 & 95.4 \\
\hline Flue Gas Moisture Capture Rate [mol/hr]: & 6,907 & 6,434 & 5,349 & 4,719 & 4,875 & 4,189 & 2,615 & 1,637 \\
\hline Flue Gas Moisture Capture Efficiency: & $19.10 \%$ & $19.18 \%$ & $18.74 \%$ & $18.40 \%$ & $18.93 \%$ & $18.34 \%$ & $17.21 \%$ & $13.27 \%$ \\
\hline Feedwater Exit Temp $\left[{ }^{\circ} \mathrm{F}\right]:$ & 222.3 & 221.0 & 219.5 & 217.6 & 215.9 & 213.7 & 198.9 & 195.1 \\
\hline FWH $\varepsilon:$ & 1.000 & 1.000 & 1.000 & 1.000 & 1.000 & 1.000 & 1.000 & 1.000 \\
\hline Feedwater Flow Rate thru FWH [lb/hr]: & $3,062,964$ & $3,058,864$ & $3,054,297$ & $3,048,428$ & $3,043,372$ & $3,036,604$ & $2,992,275$ & $2,981,151$ \\
\hline Total Water captured [lb/hr]: & 124,437 & 115,910 & 96,369 & 85,009 & 87,822 & 75,466 & 47,106 & 29,488 \\
\hline
\end{tabular}




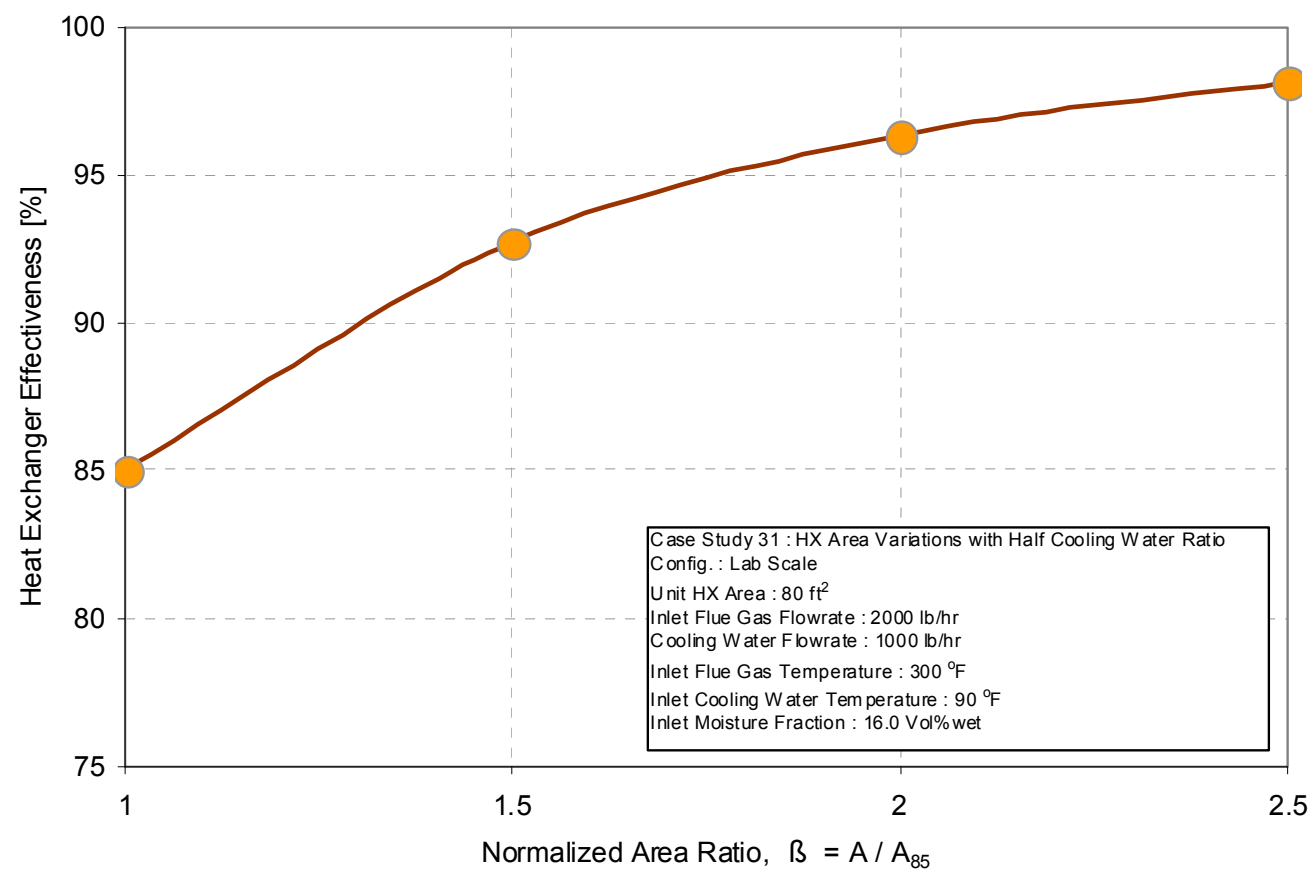

Figure 6-6: Heat Exchanger Effectiveness as a Function of Normalized Heat Exchanger Surface Area.

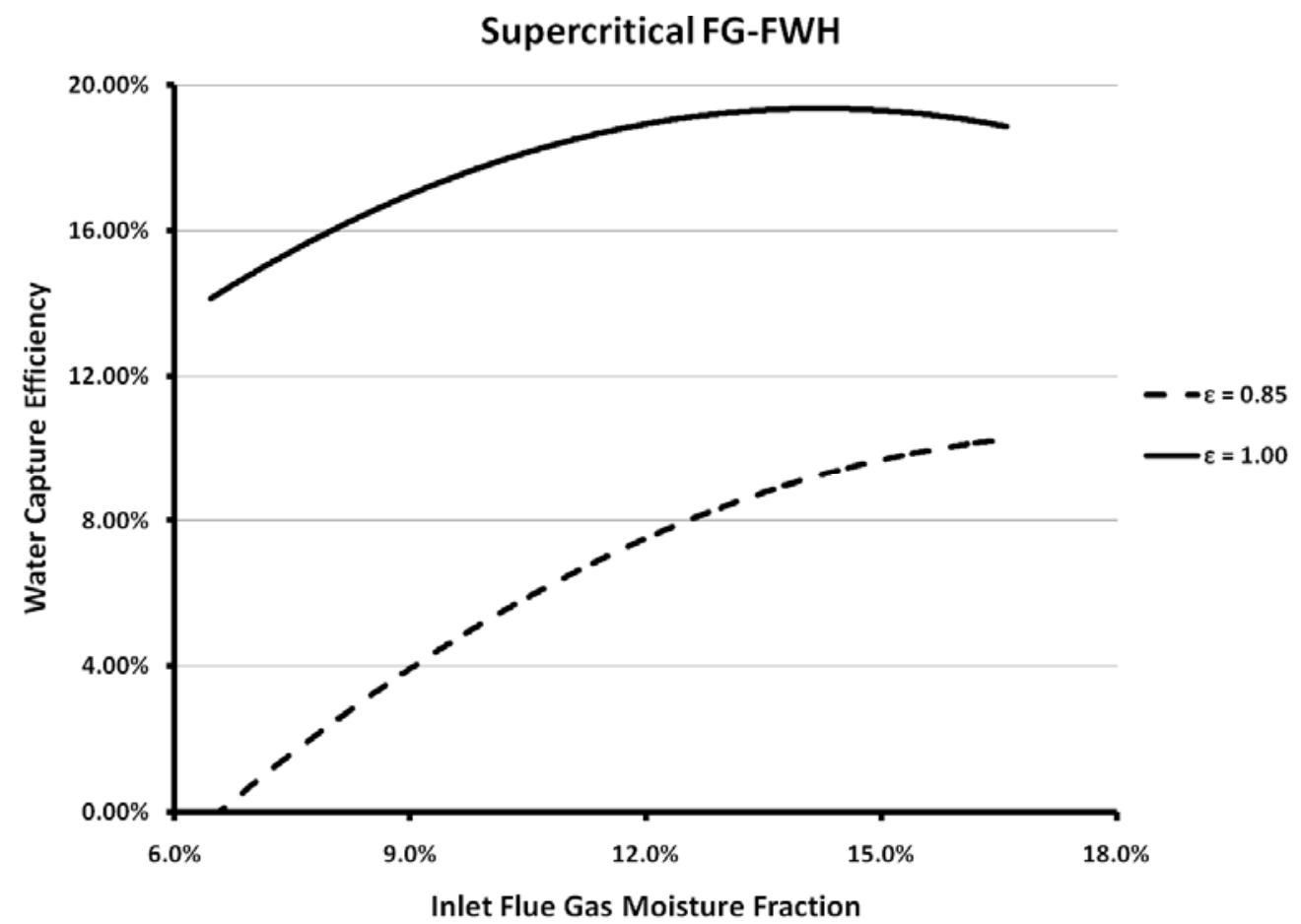

Figure 6-7: Comparison of Flue Gas Water Capture Efficiencies for FG-FWH Heat Exchanger Effectiveness Values of 0.85 and 1.00 . 


\section{Steam Turbine Cycle Analysis: Supercritical Case}

To determine the impact of the flue gas feedwater heater on turbine cycle heat rate, an analysis of the original steam cycle was needed. The net work, heat in, turbine efficiencies, and mass flow rates were evaluated. The detailed steam turbine cycle is given in Figure 6-3, and a simplified diagram is shown in Figure 6-8.

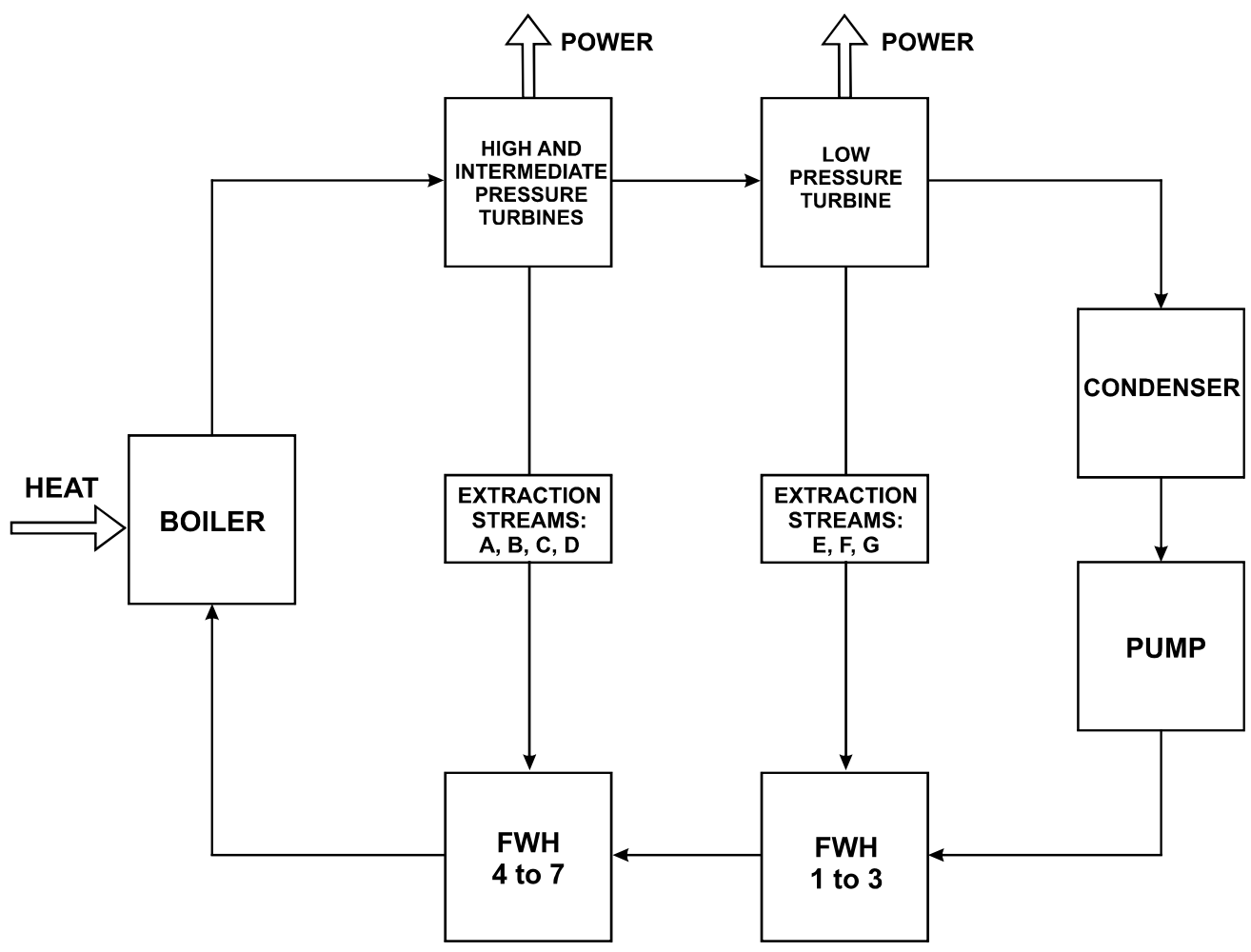

Figure 6-8: Simplified Diagram of Steam Turbine Cycle.

Using the information from Figure 6-3, the efficiencies of the various pumps, turbines and boiler and heat inputs were calculated. (See Table 6-4.)

ASPEN Plus was then used, along with the component efficiencies in Table 6-4 to calculate the overall performance of the cycle shown in Figure 6-3. To do this, the same discharge pressures and isentropic efficiencies used for the turbines and pumps and feedwater heater effectiveness values in Figure 6-3 and Table 6-4 were provided as inputs to ASPEN. The results were then compared to the results from the turbine kit (that is, the results of calculations from the original steam turbine cycle vendor) as shown in Table 6-5. The calculated results for the net work, heat inputs, and turbine 
cycle heat rate agree closely with values from the Turbine Kit. This verifies that the ASPEN simulations performed here are consistent with the calculated cycle performance results originally obtained by the steam cycle equipment vendor.

Table 6-4: Supercritical Unit Component Performance

\begin{tabular}{|c|c|c|}
\hline Component & Pressure Range & Efficiency \\
\hline HP Turbine & 3675 psig -740 psia & $85.08 \%$ \\
IP Turbine B & 666.0 psia -295.0 psia & $83.54 \%$ \\
IP Turbine C & 295.0 psia -165.1 psia & $86.48 \%$ \\
LP Turbine D & 165.1 psia -87.4 psia & $87.50 \%$ \\
LP Turbine E & 87.4 psia -24.9 psia & $89.69 \%$ \\
LP Turbine F & 24.9 psia -11.96 psia & $89.87 \%$ \\
LP Turbine G & 11.96 psia -4.69 psia & $89.73 \%$ \\
LP Turbine EXT & 4.68 psia $-1.25 " ~ H g$ & $67.25 \%$ \\
BFP Turbine & 160.1 psia - $1.25 " ~ H g$ & $79.98 \%$ \\
Booster Pump & 82.2 psia - 375 psia & $92.52 \%$ \\
Boiler Feed Pump & 290 psia - 4615 psia & $82.88 \%$ \\
\hline
\end{tabular}

Table 6-5: Comparison of ASPEN Plus Steam Cycle Performance Values to Turbine Kit Values

\begin{tabular}{|c|c|c|c|}
\hline Performance Parameters & Turbine Kit & ASPEN Plus & \% Difference \\
\hline mass flow rate thru boiler (lb/hr) & $4,184,734$ & $4,184,734$ & $0.00 \%$ \\
\hline mass flow rate thru reheat $(\mathrm{lb} / \mathrm{hr})$ & $3,677,525$ & $3,677,525$ & $0.00 \%$ \\
\hline$\Delta \mathrm{h}$ thru boiler (Btu/lb) & 922.3 & 919.541 & $0.30 \%$ \\
\hline$\Delta \mathrm{h}$ thru reheat $(\mathrm{Btu} / \mathrm{lb})$ & 248.9 & 252.395 & $1.40 \%$ \\
\hline W pumps (kW) & 1,343 & 1,343 & $0.00 \%$ \\
\hline W out $(\mathrm{kW})$ & 625,496 & 625,366 & $0.02 \%$ \\
\hline W net $(\mathrm{kW})$ & 624,153 & 624,023 & $0.02 \%$ \\
\hline $\mathrm{Q}$ boiler (Btu/hr) & $3,859,580,168$ & $3,848,031,730$ & $0.30 \%$ \\
\hline Q reboil (Btu/hr) & $915,335,973$ & $928,189,734$ & $1.40 \%$ \\
\hline $\mathrm{Q}$ in $(\mathrm{Btu} / \mathrm{hr})$ & $4,774,916,141$ & $4,776,221,464$ & $0.03 \%$ \\
\hline Heat Rate (Btu/kW-hr) & 7,650 & 7,654 & $0.05 \%$ \\
\hline HP Turbine kW & 184,299 & 183,730 & $0.29 \%$ \\
\hline IP Turbine kW & 172,656 & 171,611 & $0.61 \%$ \\
\hline LP Turbine (165.1 to 87.4 psia) (kW) & 57435.6 & 57612.7 & $0.31 \%$ \\
\hline LP Turbine (87.4 to 24.9 psia) (kW) & 84861.9 & 85055.8 & $0.23 \%$ \\
\hline LP Turbine (24.9 to 11.96 psia) (kW) & 39162.4 & 39212.6 & $0.13 \%$ \\
\hline $\begin{array}{l}\text { LP Turbine (11.96 to } 4.68 \text { psia }(\mathrm{kW}) \\
\text { LP Turbine (4.68 psia to } 1.25 " \mathrm{Hg})\end{array}$ & 42850.4 & 42921.0 & $0.16 \%$ \\
\hline$(\mathrm{kW})$ & 55736.0 & 55626.6 & $0.20 \%$ \\
\hline TOTAL (kW) & 626598 & 625366 & $0.20 \%$ \\
\hline
\end{tabular}




\section{Steam Turbine Cycle With Flue Gas Feedwater Heater}

Results of ASPEN Plus simulations for the steam turbine cycle with a flue gas feedwater heater arrangement (see Figure 6-9) are shown in Tables 6-6 and 6-7 for the four coals. Table 6-6 compares each of the steam turbine extraction flow rates with the four coals to those in the original steam cycle and Table 6-7 compares the turbine outputs, pump power and steam cycle heat rates.

The largest effect of using the flue gas feedwater heater occurs in the net work from the low pressure turbine, however, there is also a small difference in pump work. The booster pump is not affected, however the flue gas feedwater heater does affect the power requirements for the drain pumps, since they pump less water due to the reduction in steam extraction flow rate.

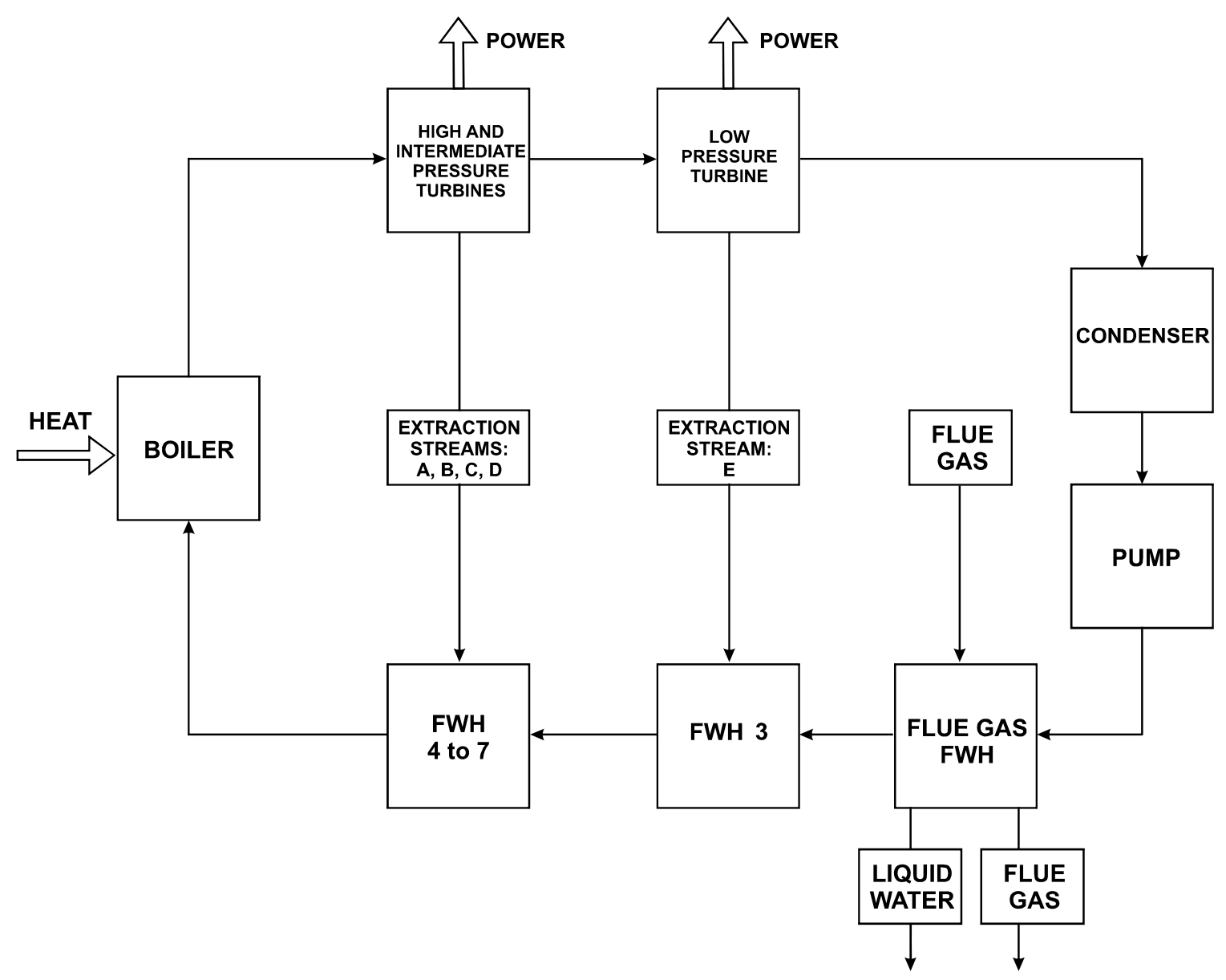

Figure 6-9: Steam Turbine Cycle with Flue Gas Feedwater Heater. 
Table 6-6: Effect of Flue Gas Feedwater Heater on Supercritical Steam Turbine Extraction Flow Rates

\begin{tabular}{|c|c|c|cc|cc|cc|cc|}
\hline \multirow{2}{*}{ FWH } & Extraction & Original & \multicolumn{2}{|c|}{ LIGNITE } & \multicolumn{2}{c|}{ Beulah-Zap } & \multicolumn{2}{c|}{ PRB } & \multicolumn{2}{c|}{ Illinois \#6 } \\
& Stream & Cycle & Summer & Winter & Summer & Winter & Summer & Winter & Summer & Winter \\
\hline 1 & G $[\mathrm{lb} / \mathrm{hr}]:$ & 178,947 & 0 & 0 & 0 & 0 & 0 & 0 & 0 & 0 \\
2 & F [lb/hr]: & 114,535 & 0 & 0 & 0 & 0 & 0 & 0 & 29,089 & 38,550 \\
3 & E $[\mathrm{lb} / \mathrm{hr}]:$ & 109,004 & 78,093 & 81,342 & 85,082 & 89,664 & 94,107 & 99,344 & 109,004 & 109,004 \\
5 & C [lb/hr]: & 163,003 & 89,166 & 89,166 & 89,166 & 89,166 & 89,166 & 89,166 & 89,166 & 89,166 \\
6 & B [lb/hr]: & 184,533 & 163,003 & 163,003 & 163,003 & 163,003 & 163,003 & 163,003 & 163,003 & 163,003 \\
7 & A [lb/hr]: & 432,374 & 432,374 & 432,374 & 432,374 & 432,374 & 432,374 & 432,374 & 432,374 & 432,374 \\
\hline
\end{tabular}

Table 6-7: Effects of FG-FWH on Supercritical Turbine Cycle Power and Heat Rate

\begin{tabular}{|c|c|c|c|c|c|c|c|c|c|}
\hline \multirow[b]{2}{*}{ Performance Parameters } & \multirow{2}{*}{$\begin{array}{c}\text { Original } \\
\text { Cycle }\end{array}$} & \multicolumn{2}{|c|}{ Lignite FWH } & \multicolumn{2}{|c|}{ BZap FWH } & \multicolumn{2}{|c|}{ PRB FWH } & \multicolumn{2}{|c|}{ Illinois \#6 FWH } \\
\hline & & Summer & Winter & Summer & Winter & Summer & Winter & Summer & Winter \\
\hline Mass flow rate thru boiler $[\mathrm{lb} / \mathrm{hr}]:$ & $4,184,734$ & $4,184,734$ & $4,184,734$ & $4,184,734$ & $4,184,734$ & $4,184,734$ & $4,184,734$ & $4,184,734$ & $4,184,734$ \\
\hline Mass flow rate thru reheat $[\mathrm{lb} / \mathrm{hr}]:$ & $3,677,525$ & $3,677,525$ & $3,677,525$ & $3,677,525$ & $3,677,525$ & $3,677,525$ & $3,677,525$ & $3,677,525$ & $3,677,525$ \\
\hline$\Delta \mathrm{h}$ thru boiler $[\mathrm{Btu} / \mathrm{lb}]:$ & 919.541 & 919.541 & 919.541 & 919.541 & 919.541 & 919.541 & 919.541 & 919.541 & 919.541 \\
\hline$\Delta \mathrm{h}$ thru reheat $[\mathrm{Btu} / \mathrm{lb}]:$ & 252.395 & 252.395 & 252.395 & 252.395 & 252.395 & 252.395 & 252.395 & 252.395 & 252.395 \\
\hline $\mathrm{Q}$ boiler $[\mathrm{MBtu} / \mathrm{hr}]:$ & 3,848 & 3,848 & 3,848 & 3,848 & 3,848 & 3,848 & 3,848 & 3,848 & 3,848 \\
\hline$Q$ reheat $[\mathrm{MBtu} / \mathrm{hr}]:$ & 928 & 928 & 928 & 928 & 928 & 928 & 928 & 928 & 928 \\
\hline Total Q in [MBtu/hr]: & 4,776 & 4,776 & 4,776 & 4,776 & 4,776 & 4,776 & 4,776 & 4,776 & 4,776 \\
\hline High Pressure Turbine $[\mathrm{kW}]:$ & 183,730 & 183,504 & 183,504 & 183,504 & 183,504 & 183,504 & 183,504 & 183,504 & 183,504 \\
\hline Interm ediate Pressure Turbine $[\mathrm{kW}]:$ & 172,049 & 172,290 & 172,290 & 172,290 & 172,290 & 172,290 & 172,290 & 172,290 & 172,290 \\
\hline Low Pressure Turbine $[\mathrm{kW}]$ : & 280,240 & 291,283 & 291,106 & 290,902 & 290,652 & 290,410 & 290,125 & 288,420 & 288,043 \\
\hline Total Turbine Work $[\mathrm{kW}]:$ & 636,020 & 647,076 & 646,899 & 646,696 & 646,446 & 646,204 & 645,919 & 644,214 & 643,836 \\
\hline LP Turbine increase & $0.00 \%$ & $3.94 \%$ & $3.88 \%$ & $3.80 \%$ & $3.72 \%$ & $3.63 \%$ & $3.53 \%$ & $2.92 \%$ & $2.78 \%$ \\
\hline$W$ net $[\mathrm{kW}]:$ & 624,273 & 635,329 & 635,152 & 634,949 & 634,699 & 634,457 & 634,172 & 632,467 & 632,089 \\
\hline W Net Increase: & $0.00 \%$ & $1.77 \%$ & $1.74 \%$ & $1.71 \%$ & $1.67 \%$ & $1.63 \%$ & $1.59 \%$ & $1.31 \%$ & $1.25 \%$ \\
\hline Turbine Cycle Heat Rate [Btu/kW-hr]: & 7,651 & 7,518 & 7,520 & 7,522 & 7,525 & 7,528 & 7,532 & 7,552 & 7,556 \\
\hline Heat Rate Decrease: & $0.00 \%$ & $1.74 \%$ & $1.71 \%$ & $1.68 \%$ & $1.64 \%$ & $1.61 \%$ & $1.56 \%$ & $1.30 \%$ & $1.24 \%$ \\
\hline
\end{tabular}

In all cases, the coal flow rate into the boiler is the same. However, it is the additional steam flow through the last stages of the low pressure turbine caused by eliminating or reducing turbine extraction flows to feedwater heaters which increases power output and causes the improvement (decrease) in turbine cycle heat rate.

Comparing all the results, the larger the flue gas water vapor content, the larger the increase in net power output. Figure 6-10 depicts the relationship between flue gas water vapor content and turbine cycle heat rate reduction resulting from use of a flue gas feedwater heater with heat transfer effectiveness values of 85 and $100 \%$. The corresponding water capture efficiencies were shown previously in Figure 6-7. 


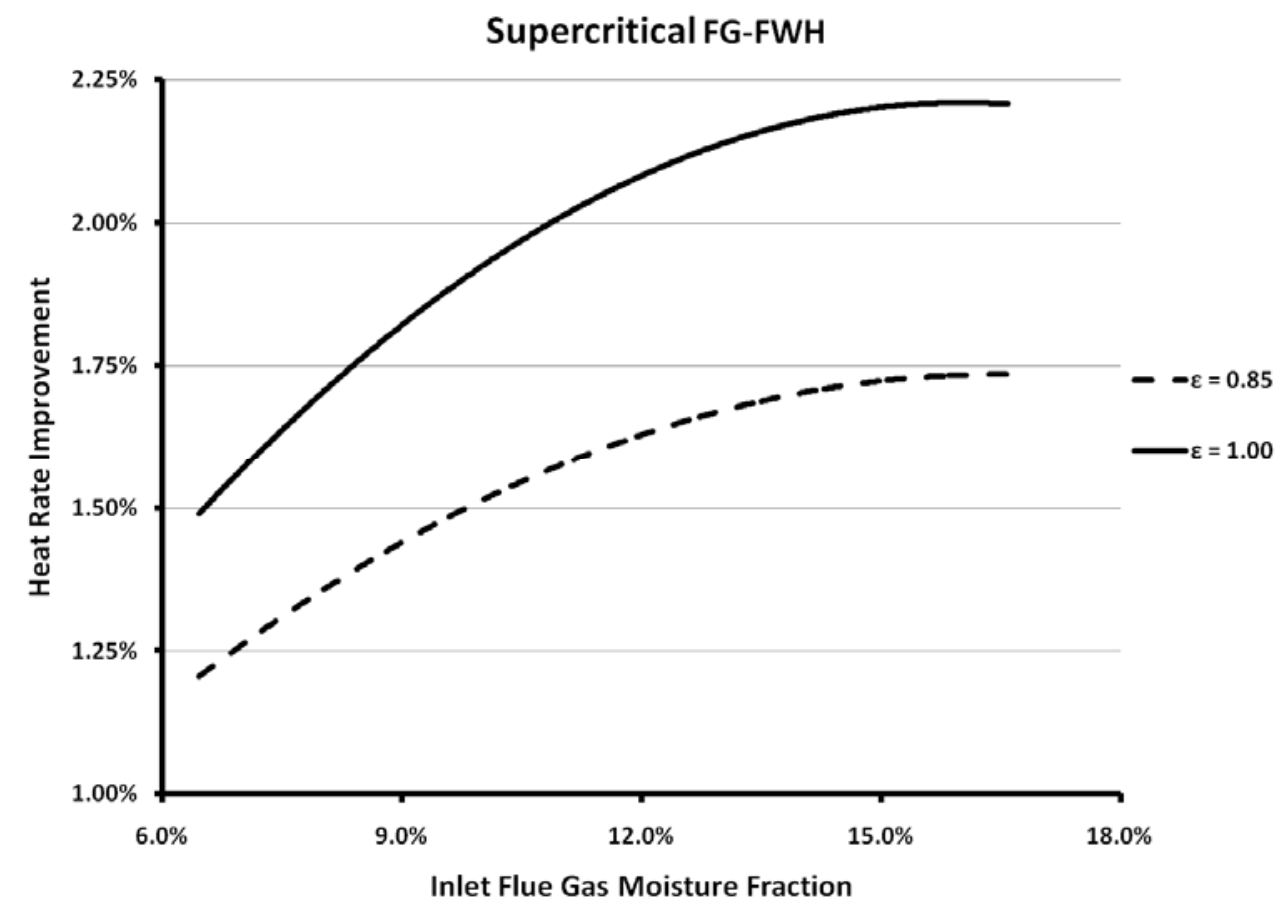

Figure 6-10: Comparison of Changes in Turbine Cycle Heat Rate with Flue Gas Water Fraction for Heat Exchanger Effectiveness Values of 0.85 and 1.00.

\section{Subcritical Steam Turbine Cycle}

Figure $6-11$ is the diagram of the steam turbine cycle for a subcritical coal-fired unit. There are seven feedwater heaters, each using turbine extraction steam to preheat the feedwater. For the conditions shown here, the feedwater enters the first feedwater heater at $105.3^{\circ} \mathrm{F}$ and is raised in temperature to $158.6^{\circ} \mathrm{F}$ by extraction stream Bleed-1 from the low pressure turbine. Similar processes in the other six feedwater heaters result in a feedwater temperature of $485.0^{\circ} \mathrm{F}$ at the economizer inlet.

As before, ASPEN Plus simulations were performed on a modified cycle in which the first two feedwater heaters were replaced by a flue gas feedwater heater (Figure 612). The analyses were performed for four coals (lignite, sub-bituminous and bituminous), all in a boiler operating with $21 \%$ excess air and with a $300^{\circ} \mathrm{F}$ air preheater gas exit temperature. See Table 6-1 for the coal analysis and volumetric flue gas composition for each coal. 


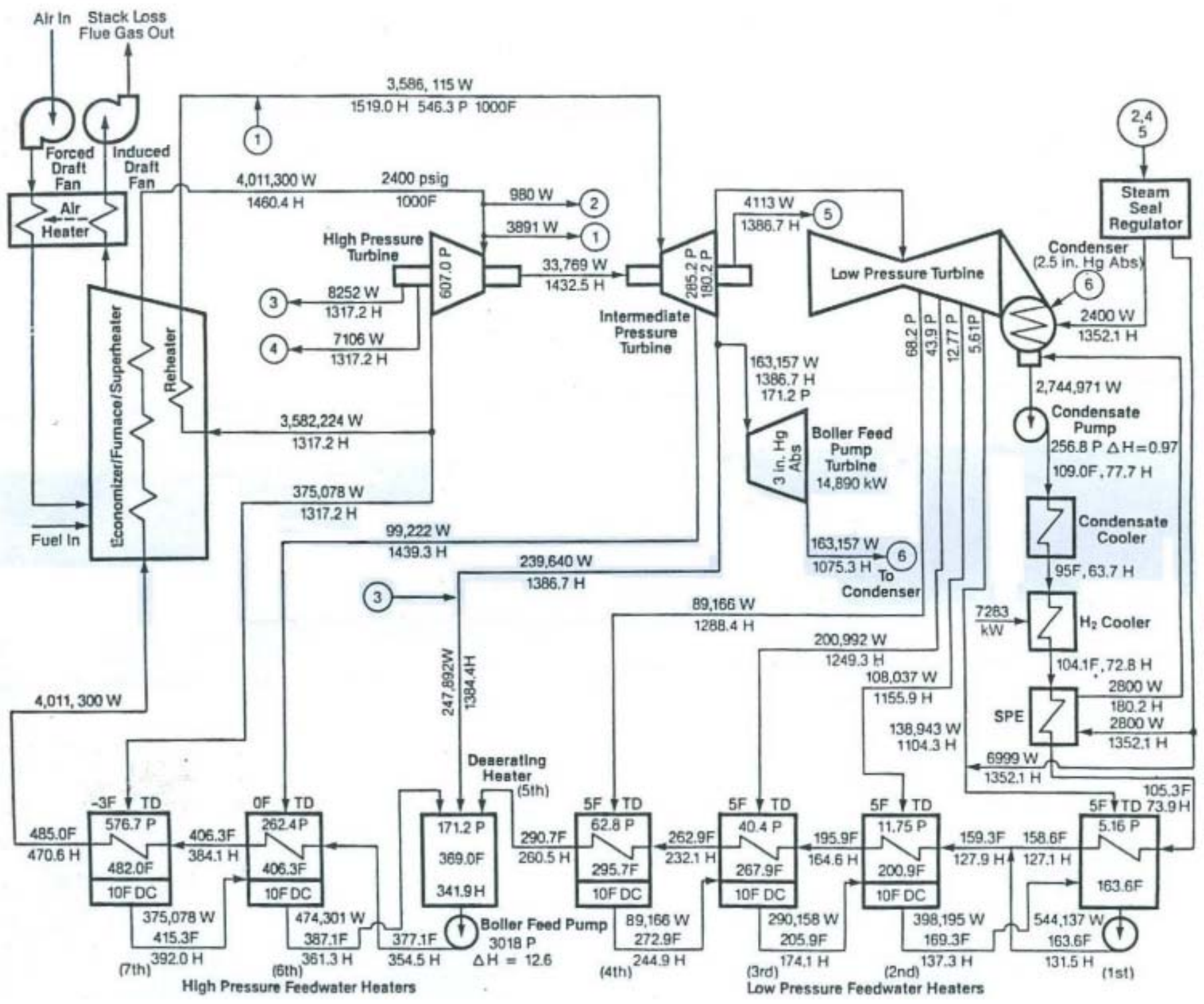

Figure 6-11: Steam Turbine Cycle Diagram of Subcritical Unit. 


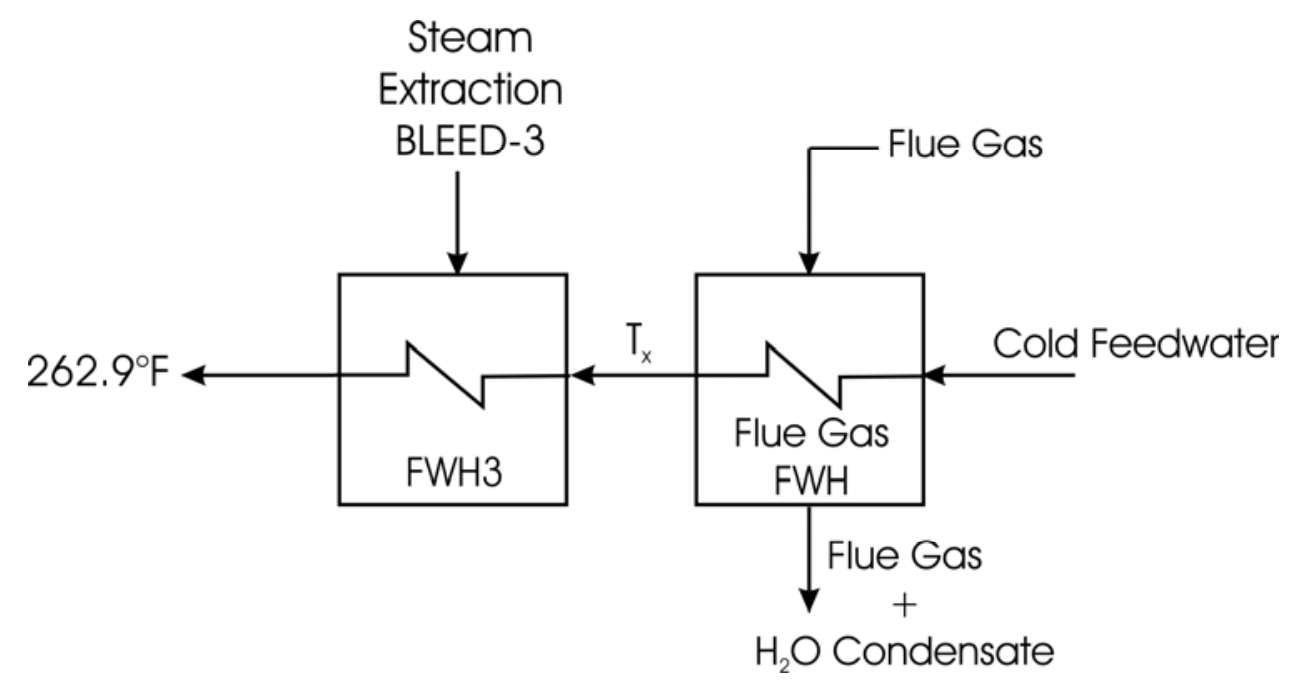

Figure 6-12: Flue Gas Feedwater Heat Exchanger - Subcritical Cycle.

The method of analysis used is the same as was used for the supercritical cycle. Figure 6-13 shows the resulting water capture efficiency for the subcritical steam cycle with FG-FWH effectiveness values of 0.85 and 1.00 and Figure 6-14 shows the corresponding heat rate improvements for both effectiveness values. Comparisons between the subcritical and supercritical cycles are shown in Figures 6-15 and 6-16 for 85 percent effectiveness. The consistently higher water capture efficiencies and larger heat rate improvements of the supercritical cycle are most likely due to it's lower inlet feedwater temperature $\left(87.1^{\circ} \mathrm{F}\right.$ versus $\left.105.3^{\circ} \mathrm{F}\right)$, as opposed to any inherent differences between subcritical and supercritical steam turbine cycles. 


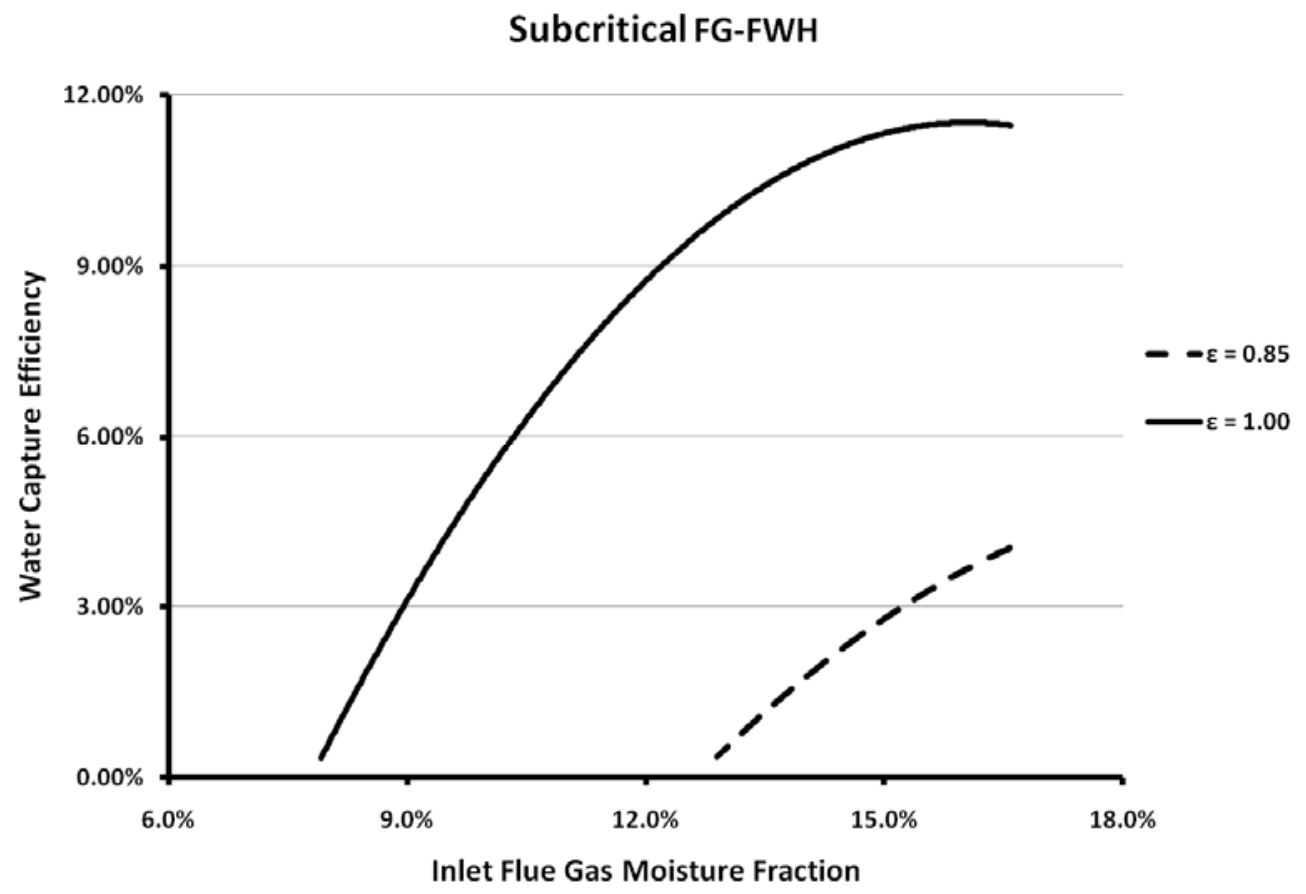

Figure 6-13: Variation of Flue Gas Water Capture Efficiency with Inlet Flue Gas Moisture Fraction. Subcritical Steam Cycle with $\varepsilon=0.85$ and 1.00 .

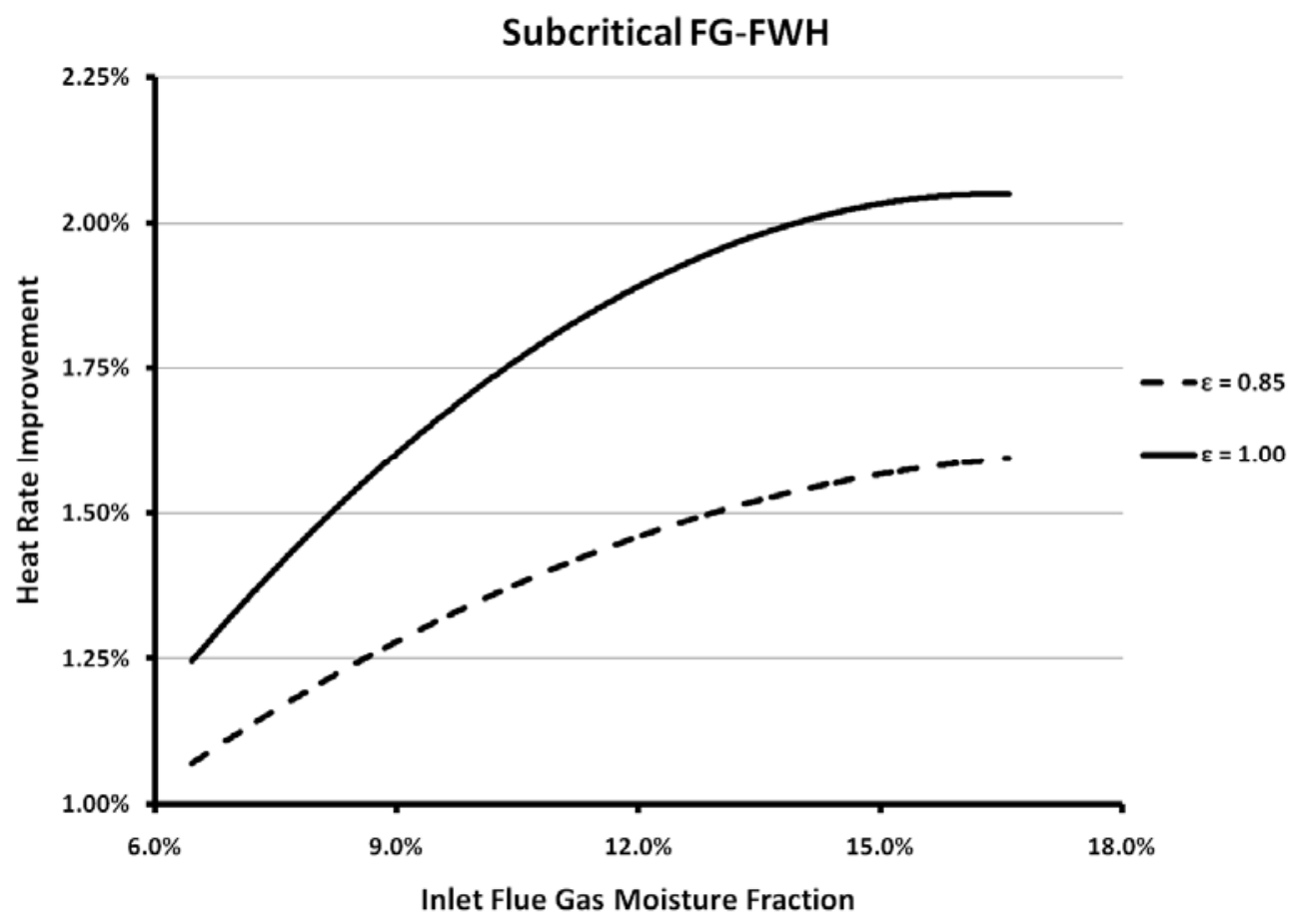

Figure 6-14: Variation of Turbine Cycle Heat Rate Improvement with Inlet Flue Gas Moisture Fraction. Subcritical Turbine Cycle with $\varepsilon=0.85$ and 1.00 . 


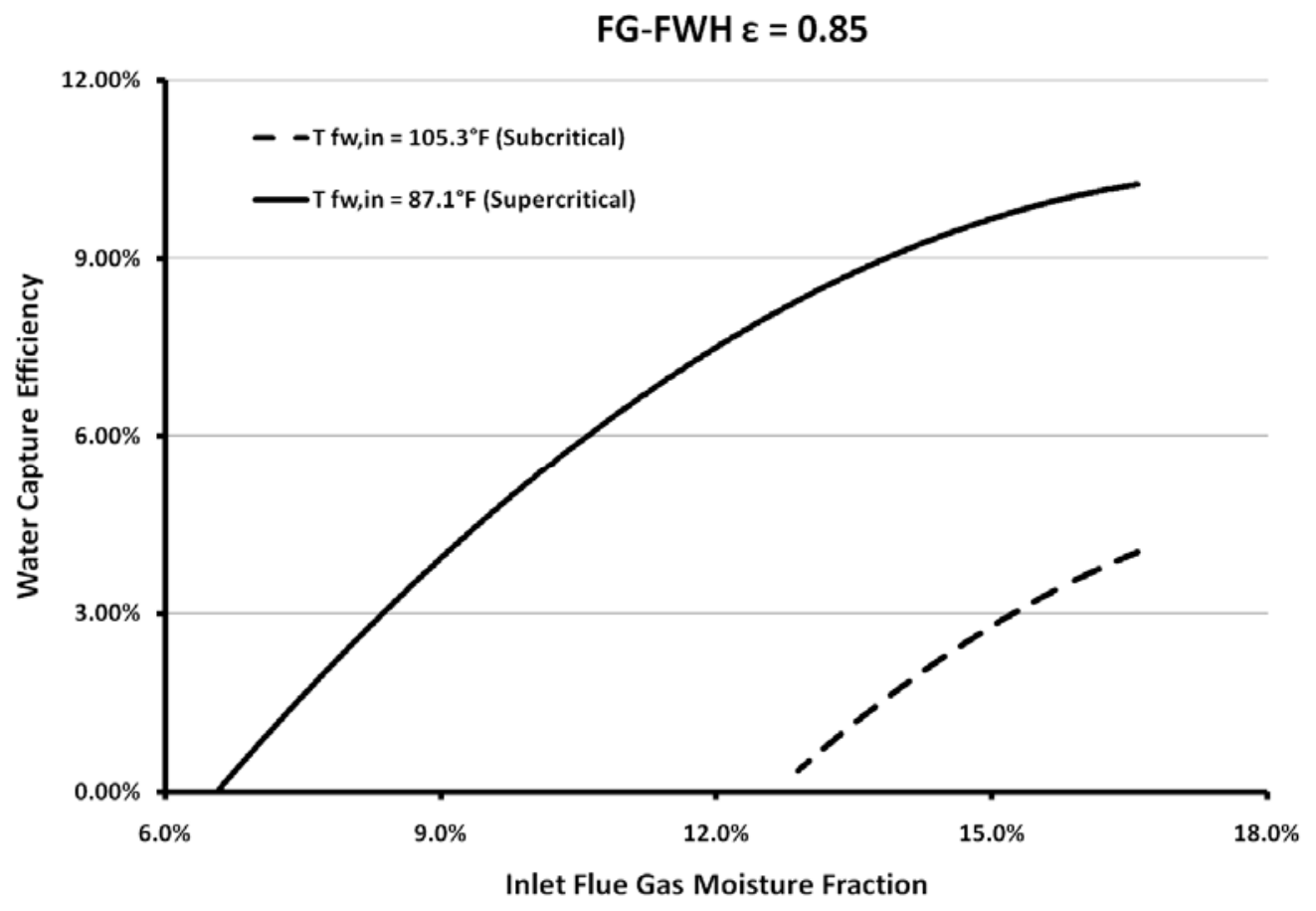

Figure 6-15: Effect of Feedwater Inlet Temperature on Water Capture Efficiency for an Effectiveness of 0.85 .

FG-FWH $\varepsilon=0.85$

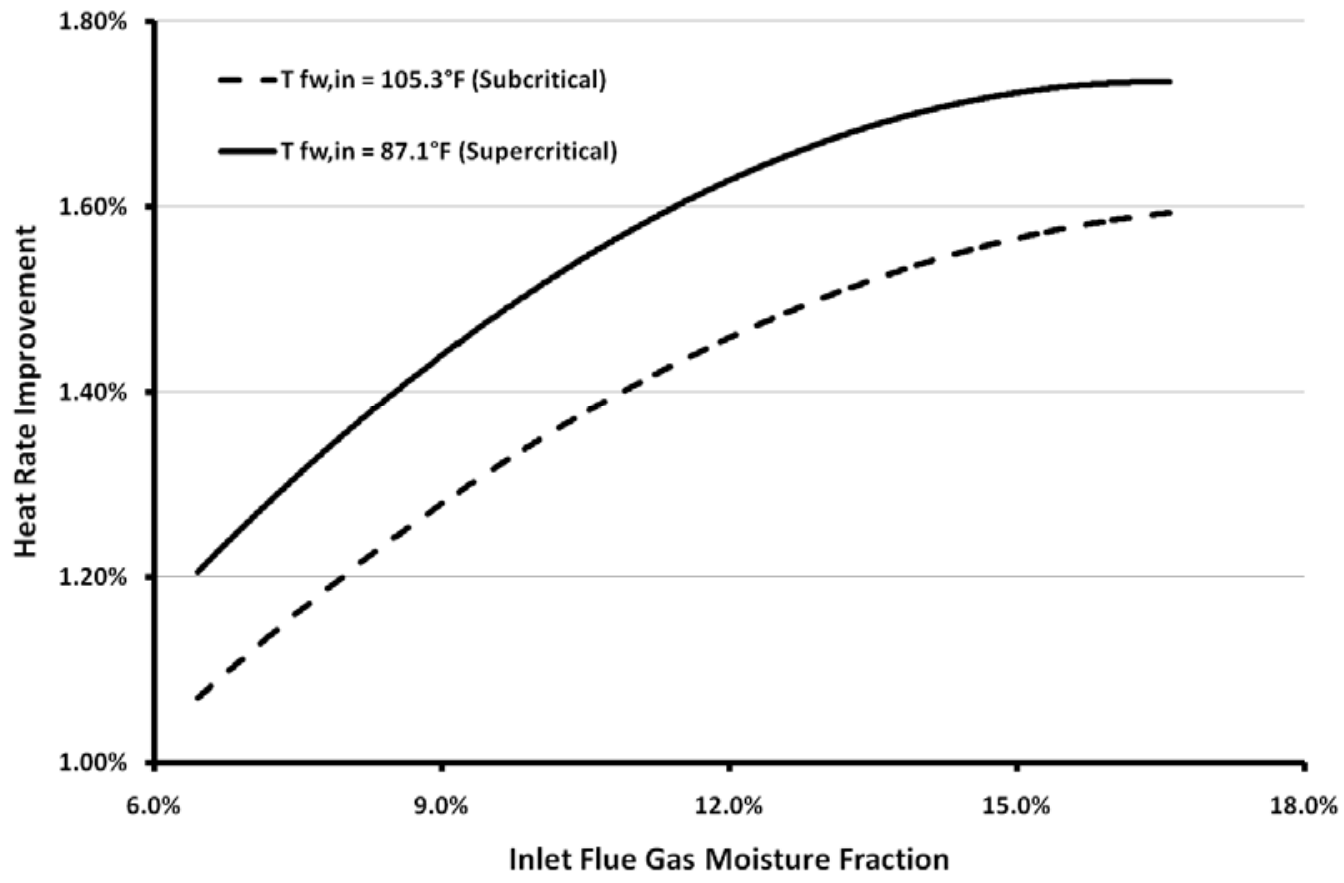

Figure 6-16: Effect of Feedwater Inlet Temperature on Turbine Cycle Heat Rate for an Effectiveness of 0.85 . 


\section{GROUP II HEAT EXCHANGERS: INLET COMBUSTION AIR AS HEAT SINK}

\section{Introduction}

After the flue gas leaves the Group I heat exchangers (FG-FWH), it passes through the Group II heat exchangers (FG-AHX1), which are used to increase the temperature of the combustion air before it enters the air preheater (APH). The FGAHX1 heat exchanger system would allow for more water vapor to condense from the flue gas and the corresponding increase in boiler air inlet temperature would increase the efficiency of the boiler and decrease unit heat rate. A simplified diagram of the combined flue gas cooling process is shown in Figure 6-17.

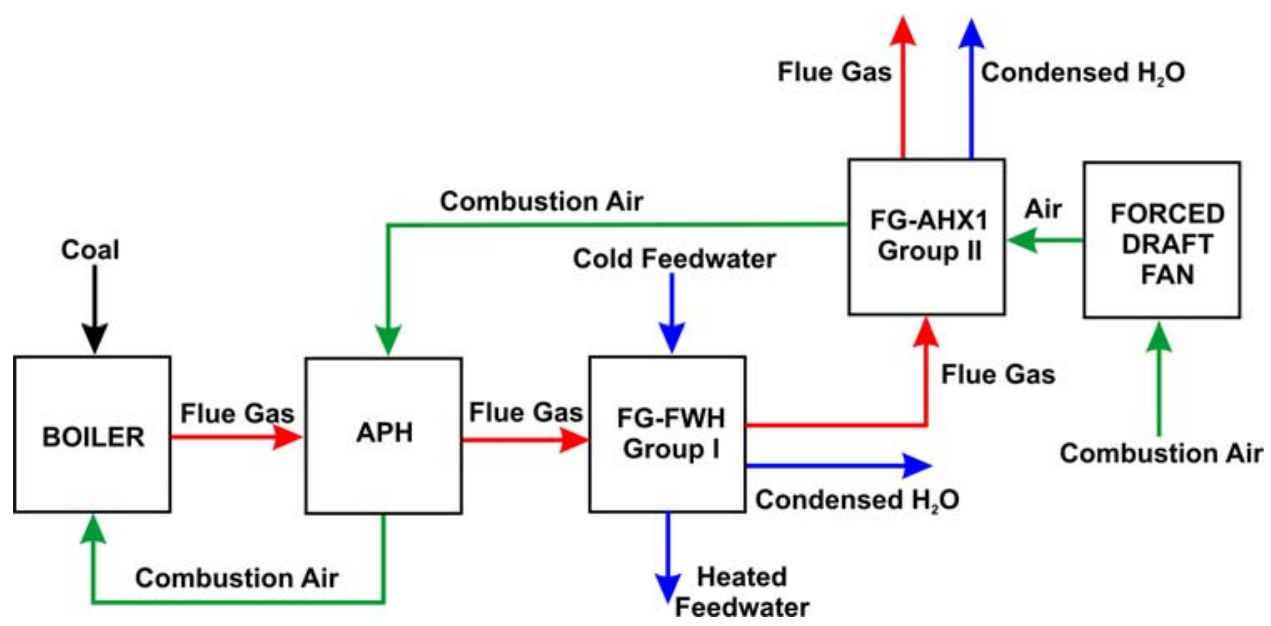

Figure 6-17: Process Diagram Showing FG-FWH and FG-AHX1 Integrated With Boiler and Auxiliary Components.

Due to the increase in boiler efficiency, less coal would be needed to produce the same amount of steam, and the reduction in coal feed rate would reduce the flow rates of combustion air and flue gas, which in turn, would affect the performance of both the FG-FWH and the FG-AHX1 heat exchange systems.

For most cases, the flue gas temperature entering FG-AHX1 will already be at its dew point. Most of the energy captured from flue gas in FG-FWH will be sensible heat, whereas most of the energy captured in FG-AHX1 will be from latent heat. It is the inlet temperature and mass flow rate of the combustion air, as well as the flue gas inlet 
temperature which will limit heat transfer in a FG-AHX1. Since flue gas has a larger specific heat and mass flow rate than combustion air, the combustion air has the lower heat capacity rate. Therefore, a heat exchanger thermal effectiveness of 100 percent would mean that the exiting combustion air temperature would reach the incoming flue gas temperature. Keeping the performance of the FG-FWH fixed, the thermal effectiveness of FG-AHX1 was varied to determine the effects of effectiveness on unit heat rate and on condensation efficiency.

The following results, for the supercritical steam turbine cycle and for FG-FWH effectiveness values of 0.85 and 1.00, show predicted impacts of FG-AHX1 thermal effectiveness on unit heat rate and on water capture efficiency. Figures 6-18 through 621 show there is a linear relationship between FG-AHX1 thermal effectiveness and water vapor capture efficiency. In Figures 6-18 and 6-20, the values for water vapor capture efficiency assume the FG-FWH heat exchangers have an effectiveness of 0.85 and the effectiveness values for the FG-AHX1 heat exchangers range from 0.0 to 1.0. Figures 6-19 and 6-21 are organized in a similar manner, except the FG-FWH heat exchangers have an effectiveness of 1.00 .

Average summer and winter ambient air temperatures of $77^{\circ} \mathrm{F}$ and $33^{\circ} \mathrm{F}$ were assumed and since there will be a much larger temperature difference between the flue gas and combustion air in the winter case, the FG-AHX1 impact on water vapor capture efficiency will be greater in winter. Figures 6-22 and 6-23 show overall water vapor capture efficiency and unit heat rate improvement for FG-FWH heat exchanger effectiveness values of 0.85 and 1.00 and a FG-AHX1 effectiveness value of 0.85 . These results show, for example, that with a PRB coal, the predicted overall heat rate improvement ranges from 2.4 to 3.5 percent, depending on the effectiveness of the FGFWH heat exchanger and ambient temperature. At the same time, the predicted overall water vapor capture efficiency for PRB coal ranges from 15 to 34 percent. 


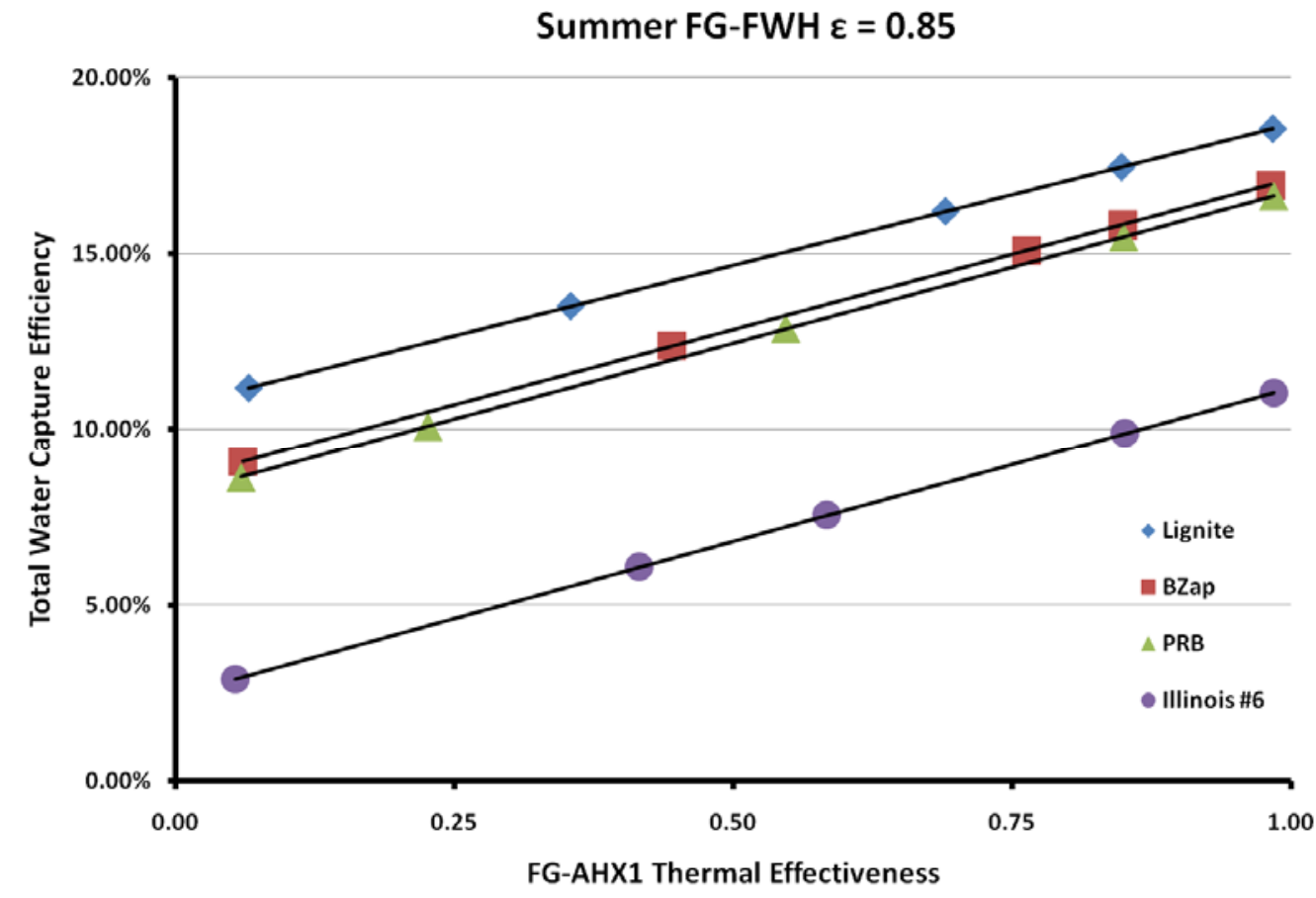

Figure 6-18: FG-AHX1 Impacts on Summer Water Capture Efficiency with FG-FWH $\varepsilon=0.85$.

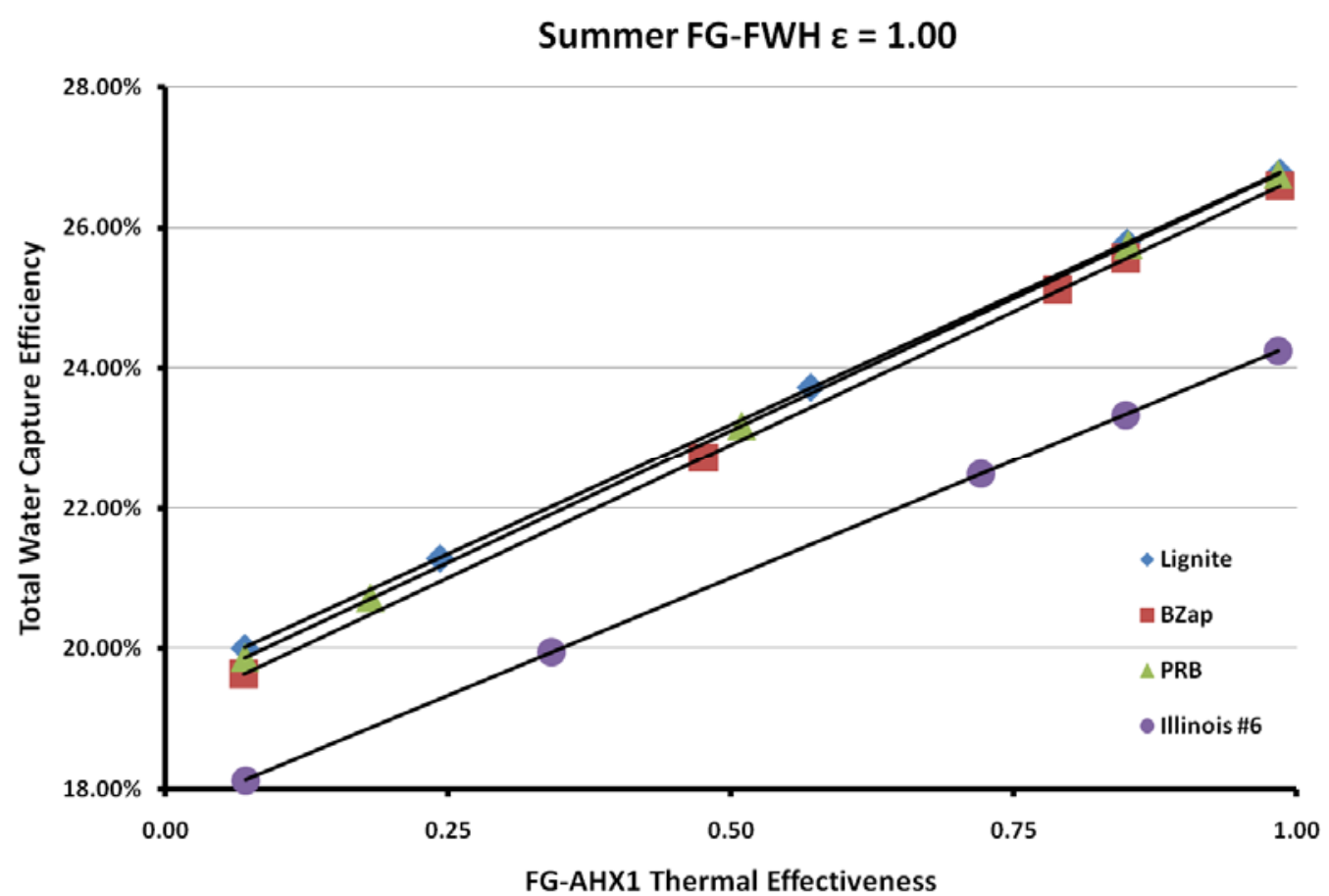

Figure 6-19: FG-AHX1 Impacts on Summer Water Capture Efficiency with FG-FWH $\varepsilon=1.00$. 


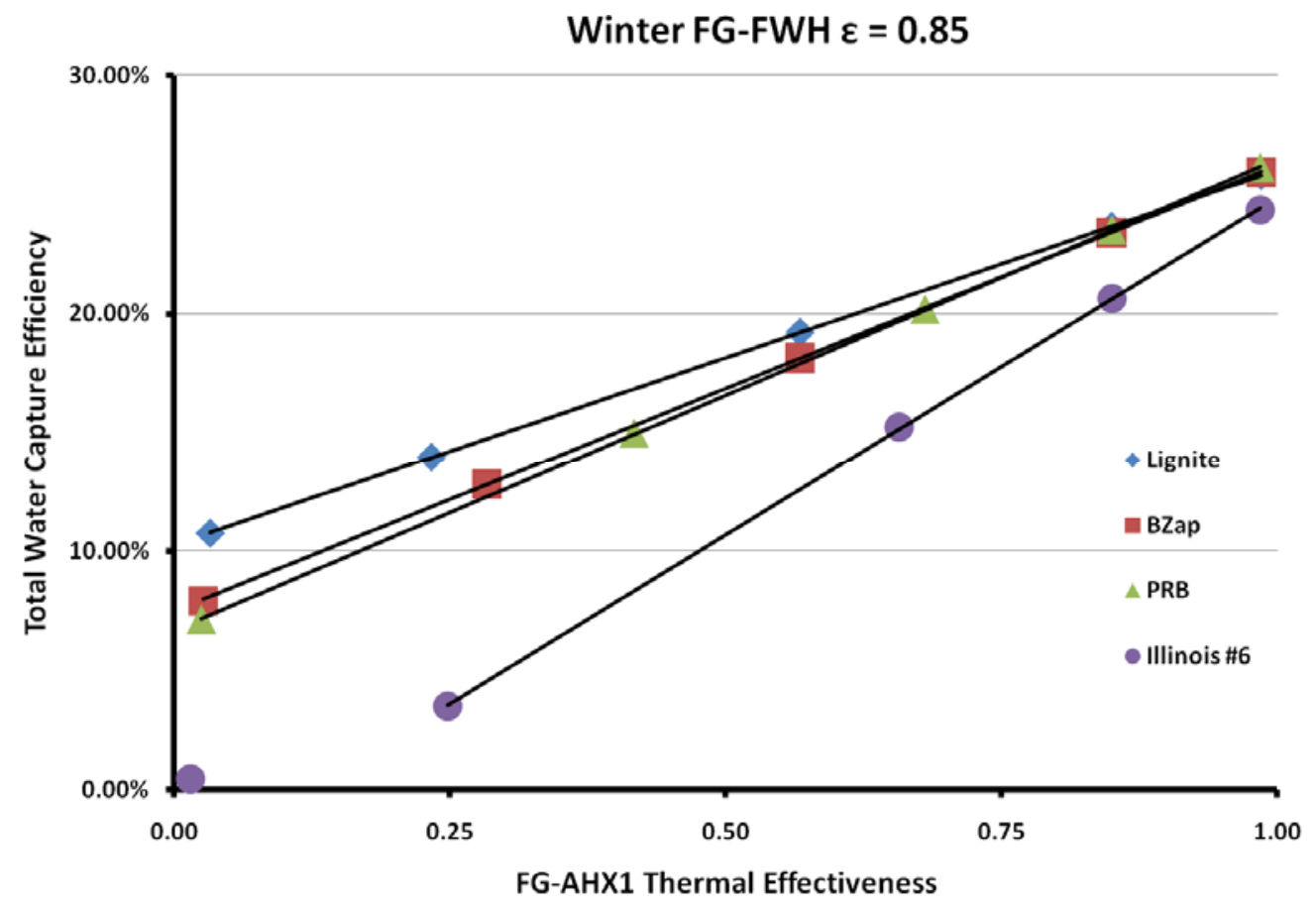

Figure 6-20: FG-AHX1 Impacts on Winter Water Capture Efficiency with FG-FWH $\varepsilon=0.85$.

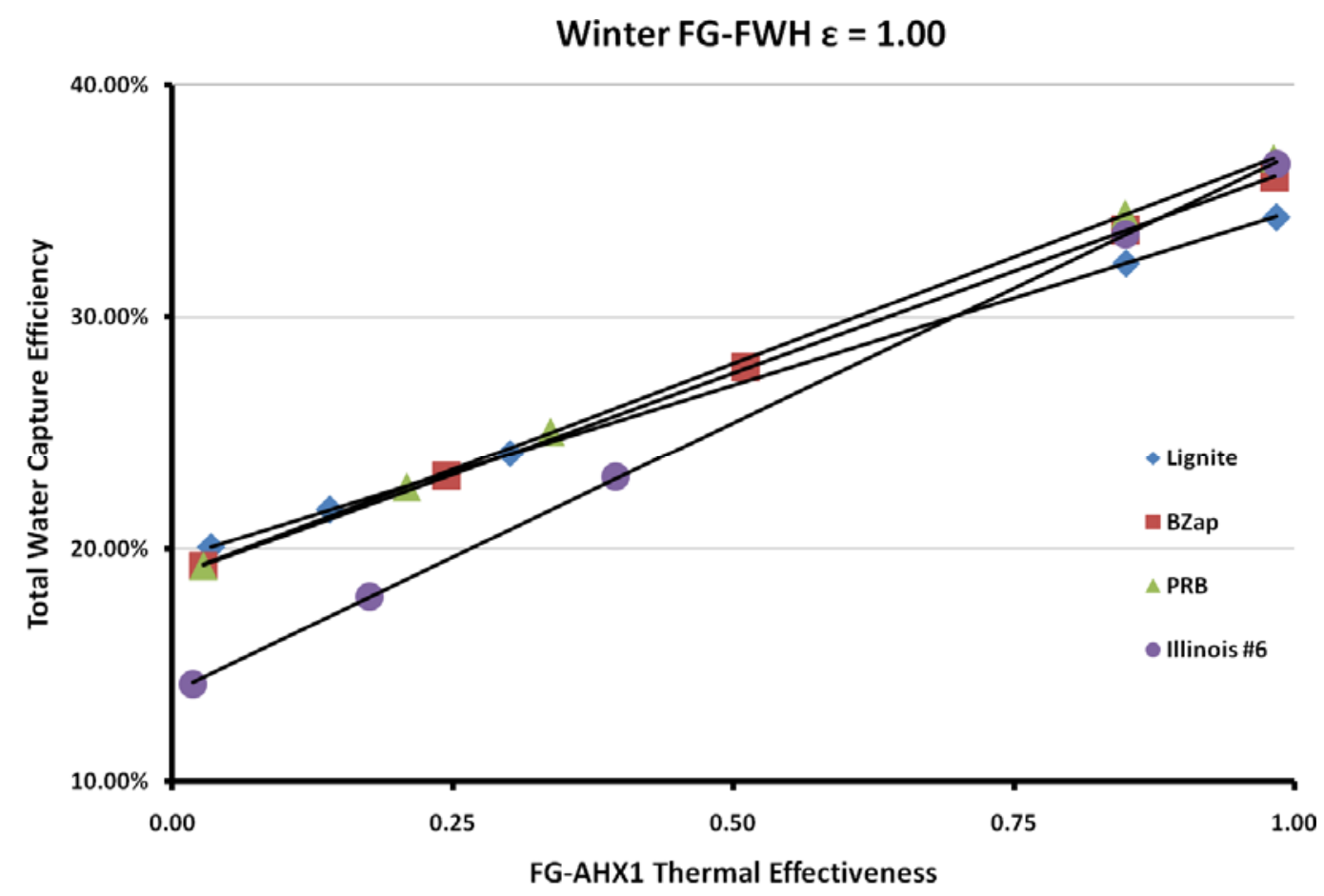

Figure 6-21: FG-AHX1 Impacts on Winter Water Capture Efficiency with FG-FWH $\varepsilon=1.00$. 


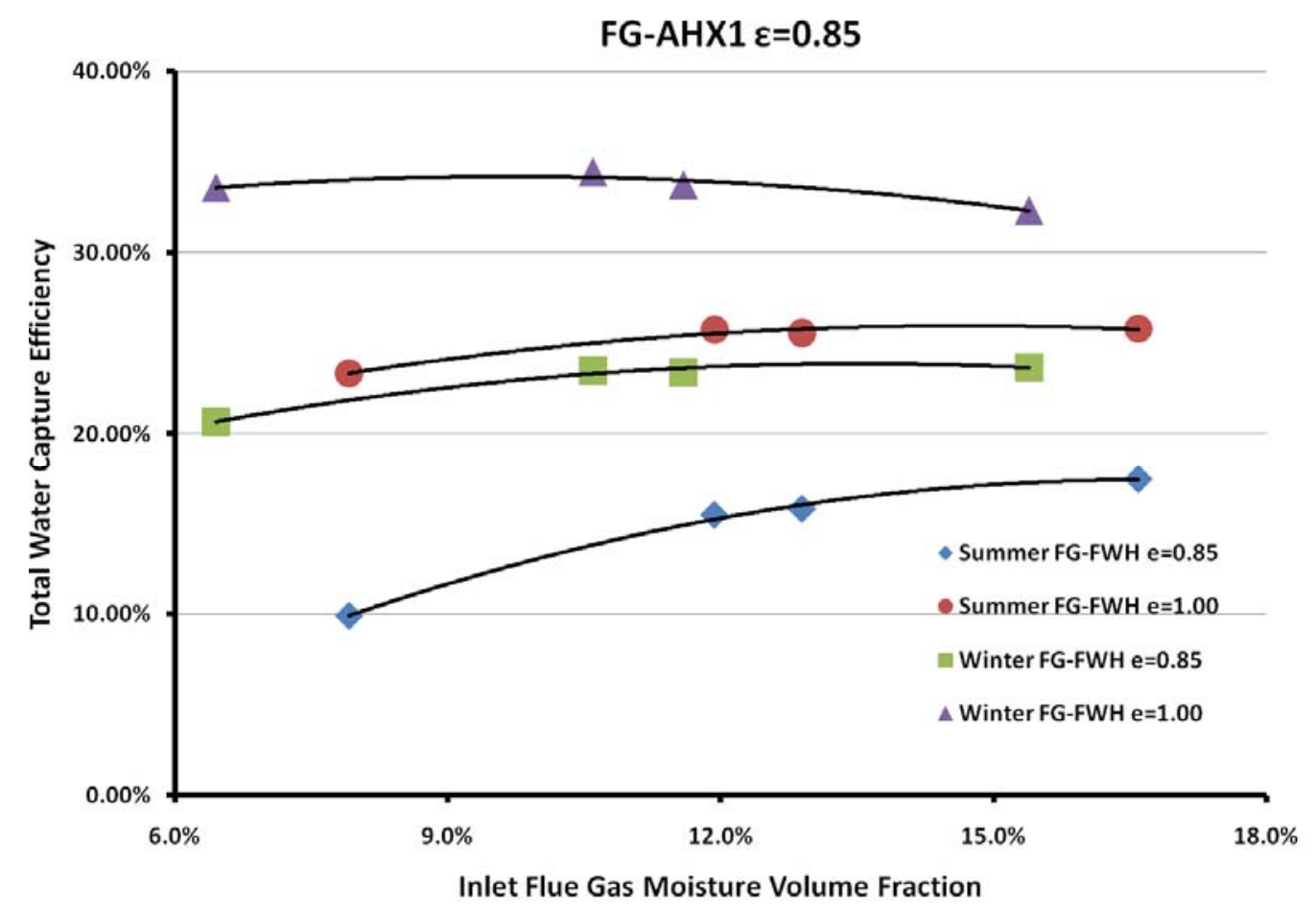

Figure 6-22: Effects of Inlet Flue Gas Moisture Fraction on Overall Water Vapor Capture Efficiency.

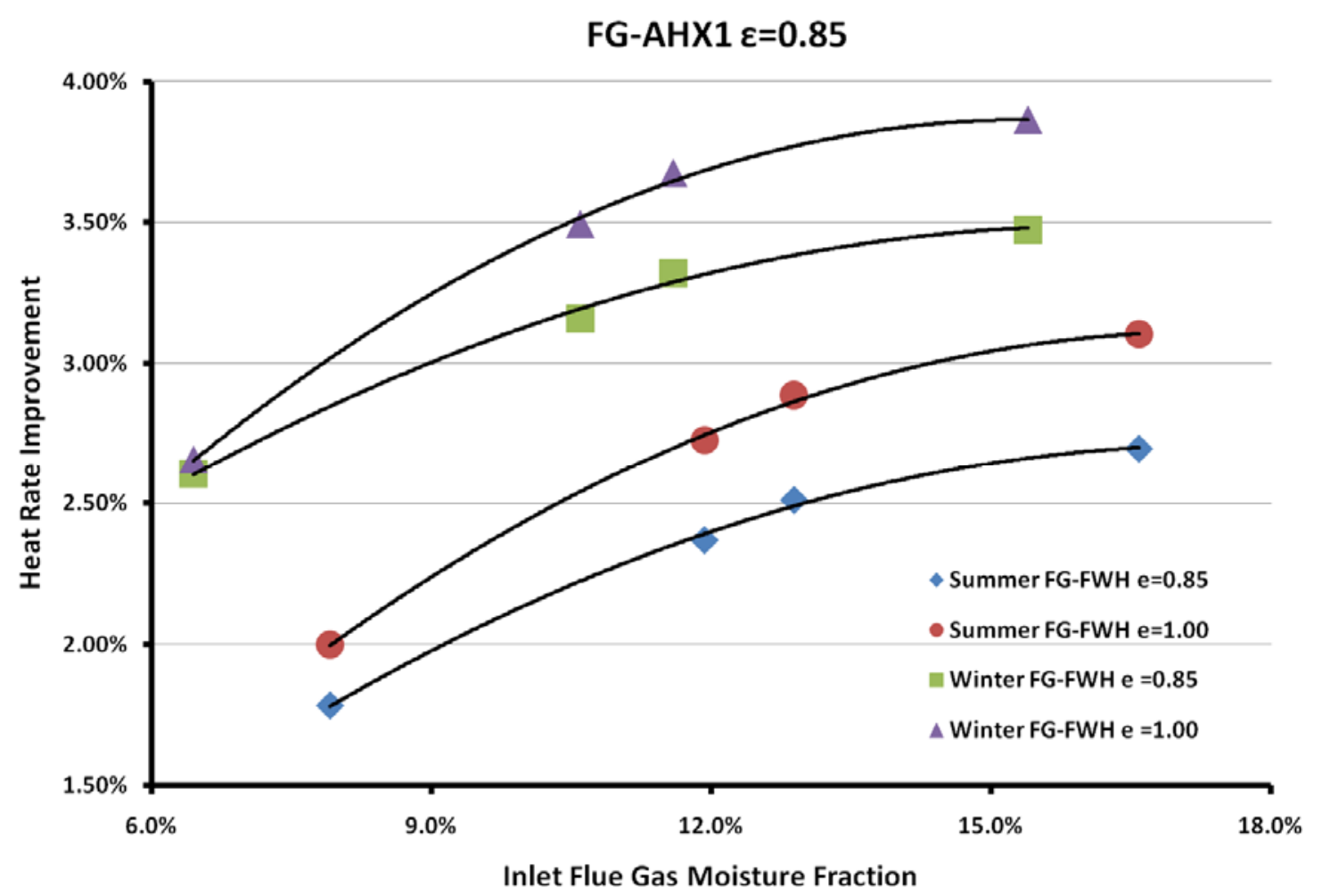

Figure 6-23: Effects of Inlet Flue Gas Moisture Fraction on Overall Unit Heat Rate Improvement. 


\section{GROUP III HEAT EXCHANGERS: USE OF ADDITIONAL AMBIENT AIR AS HEAT SINK}

In order to be able to capture any of the remaining water vapor in the flue gas, additional heat exchangers would be needed, and the Group III heat exchangers described in this section of the report would be one way to accomplish this. The Group III heat exchangers (referred to as FG-AHX2 in this report) use ambient air to cool flue gas to temperatures approaching ambient air temperature and to simultaneously condense moisture. Since thermal energy is rejected to ambient air in FG-AHX2, this heat exchange system would not have any impacts on unit heat rate, other than those caused by a possible increase in station service power due to the need for additional fan power. Figure 6-24 shows this additional step as a part of a flue gas cooling system.

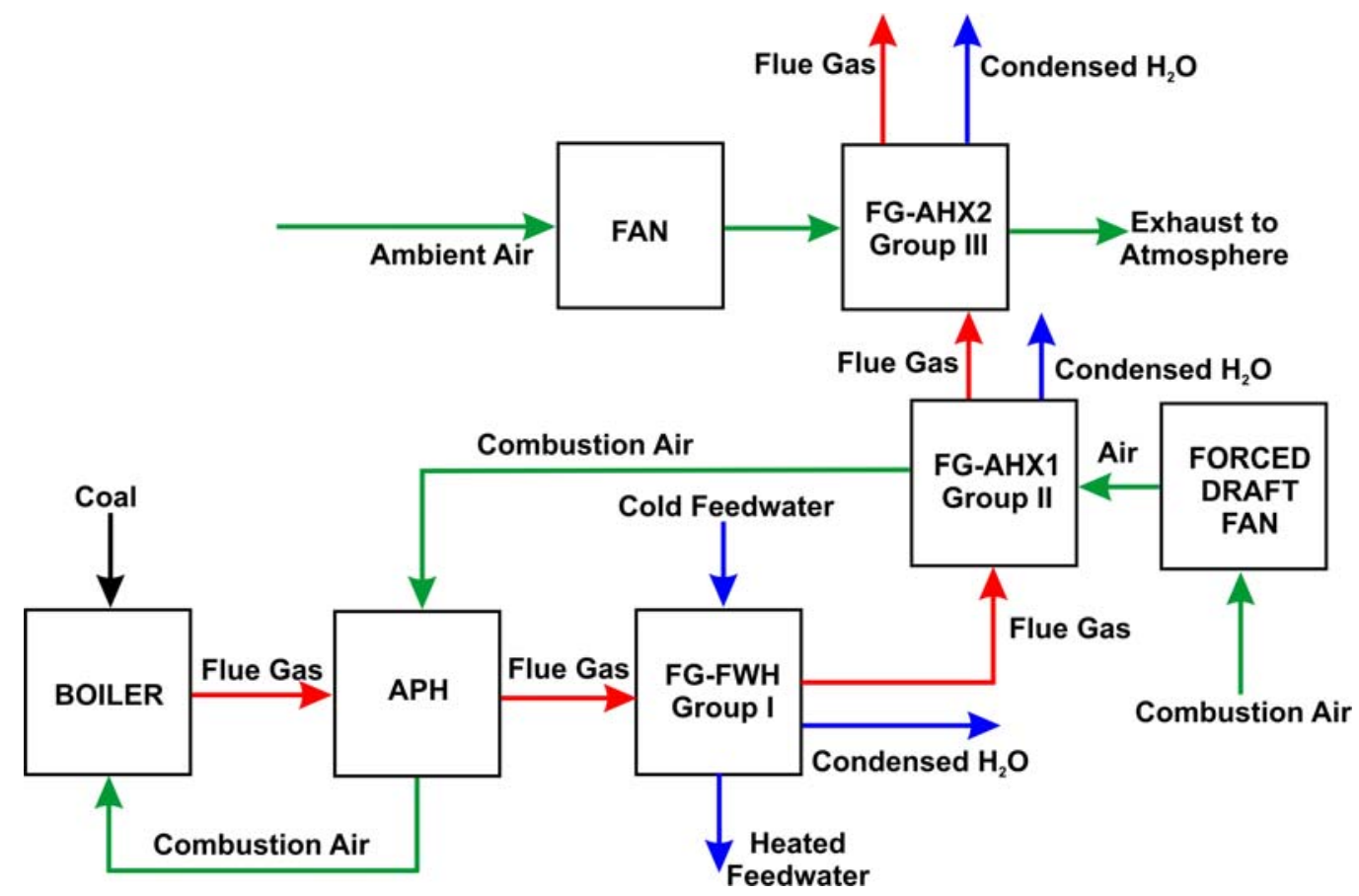

Figure 6-24: Flue Gas Cooling Process with FG-FWH, FG-AHX1 and FG-AHX2 Heat Exchangers Integrated with Boiler and Auxiliary Components.

For these analyses, winter and summer ambient air temperatures of $33^{\circ} \mathrm{F}$ and $77^{\circ} \mathrm{F}$ were assumed. In addition, a $5^{\circ} \mathrm{F}$ temperature increase across the FD fan and a 
thermal effectiveness of 85 percent was used for all three heat exchanger groups. Besides the size or effectiveness of the FG-AHX2 heat exchangers, the inlet temperature of the cooling air and the inlet moisture fraction of the flue gas are the primary factors affecting the performance of FG-AHX2.

Table 6-8 shows the water capture resulting from using the three groups of flue gas heat exchangers. The parameter, $y_{\text {initial, }}$ is the flue gas moisture volume fraction entering the Group I heat exchangers and $\mathrm{y}_{\mathrm{FWH}}, \mathrm{y}_{\mathrm{AHX} 1}$, and $\mathrm{y}_{\mathrm{AHX} 2}$ are the moisture volume fractions leaving each of the three heat exchanger groups. The $\eta_{w c}$ terms are the water capture efficiencies of the three heat exchanger groups and $M_{c d}$ is the flow rate of captured water vapor. As water is condensed from the flue gas, the moisture fraction decreases from heat exchanger to heat exchanger. The results show that for all coals and ambient temperature conditions, FG-AHX2 would be responsible for the majority of the total water captured. (Total water capture efficiency is defined here as the sum of the condensation flows from each of the flue gas heat exchangers divided by the inlet flow of flue gas water vapor.) The results also show the flue gas-to-air heat exchangers are able to capture more water in colder seasons because of a larger temperature difference between flue gas and air.

Table 6-8: Water Capture Results from the Three Flue Gas Heat Exchanger Groups

\begin{tabular}{|c|c|c|c|c|c|c|c|c|c|}
\hline & $\begin{array}{c}Y_{\text {initial }} \\
\text { [vol \%] }\end{array}$ & $\begin{array}{c}\mathrm{YFWH} \\
\text { [vol \%] }\end{array}$ & $\begin{array}{c}\mathrm{Y}_{\mathrm{AHX1}} \\
\text { [vol \%] }\end{array}$ & $\begin{array}{c}\mathrm{Y}_{\mathrm{AHX2}} \\
\text { [vol \%] }\end{array}$ & $\begin{array}{c}\eta W C \text { FWH } \\
\varepsilon=0.85\end{array}$ & $\begin{array}{c}\eta w c \text { AHX1 } \\
\varepsilon=0.85\end{array}$ & $\begin{array}{c}\eta w c \text { AHX2 } \\
\varepsilon=0.85\end{array}$ & Total nwc & $\begin{array}{c}\mathrm{mcd} \\
{[\mathrm{lb} / \mathrm{hr}]}\end{array}$ \\
\hline Lignite Summer: & 16.59 & 15.13 & 14.10 & 5.36 & $10.38 \%$ & $7.08 \%$ & $54.06 \%$ & $71.5 \%$ & 461,242 \\
\hline BZap Summer: & 12.89 & 11.95 & 11.08 & 4.85 & $8.25 \%$ & $7.56 \%$ & $49.75 \%$ & $65.6 \%$ & 334,299 \\
\hline PRB Summer: & 11.93 & 11.10 & 10.27 & 4.72 & $7.80 \%$ & $7.68 \%$ & $47.95 \%$ & $63.4 \%$ & 291,884 \\
\hline Illinois\#6 Summer: & 7.91 & 7.77 & 7.19 & 4.23 & $2.02 \%$ & $7.87 \%$ & $38.70 \%$ & $48.6 \%$ & 132,302 \\
\hline Lignite Winter: & 15.39 & 14.06 & 12.19 & 2.35 & 0.00 & $13.57 \%$ & $63.11 \%$ & $76.7 \%$ & 514,678 \\
\hline BZap Winter: & 11.59 & 10.85 & 9.13 & 1.89 & $7.23 \%$ & $16.18 \%$ & $61.87 \%$ & $85.3 \%$ & 387,260 \\
\hline PRB Winter: & 10.60 & 9.99 & 8.31 & 1.78 & $6.39 \%$ & $17.13 \%$ & $61.19 \%$ & $84.7 \%$ & 342,729 \\
\hline Illinois\#6 Winter: & 6.46 & 6.46 & 5.15 & 1.34 & $0.00 \%$ & $21.37 \%$ & $58.97 \%$ & $80.3 \%$ & 175,983 \\
\hline
\end{tabular}

Table 6-9 lists the final flue gas exit temperature, FGET, its terminal temperature difference $(\Delta T 2)$, the air flow rates through FG-AHX1 and FG-AHX2, and the air flow rate ratio. For the summer lignite case, the air flow rate through FG-AHX2 would be 
over 9 times as large as the combustion air flow rate. Figure 6-25 shows how predicted total water capture efficiency increases with increasing inlet moisture fraction and cooler air temperatures. The required air flow rate through FG-AHX2 increases with moisture fraction, but decreases with air temperatures as shown in Figure 6-26.

Table 6-9: Flue Gas-to-Air Heat Exchanger Results

\begin{tabular}{|r|ccccc|}
\hline & $\begin{array}{c}\text { FGET } \\
{\left[{ }^{\circ} \mathbf{F}\right]}\end{array}$ & $\begin{array}{c}\Delta \mathbf{T} 2 \\
{\left[{ }^{\circ} \mathbf{F}\right]}\end{array}$ & $\begin{array}{c}\mathbf{M}_{\text {Comb Air }} \\
{[\mathbf{l b} / \mathbf{h r}]}\end{array}$ & $\begin{array}{c}\mathbf{M}_{\text {AHX2 }} \\
{[\mathbf{l b} / \mathbf{h r}]}\end{array}$ & $\begin{array}{c}\mathbf{M}_{\text {AHX2 }} \\
\mathbf{M}_{\text {COMB.AIR }}\end{array}$ \\
\hline Lignite Summer: & 93.17 & 11.17 & $4,798,121$ & $43,900,000$ & 9.15 \\
BZap Summer: & 90.21 & 8.21 & $5,082,349$ & $40,500,000$ & 7.97 \\
PRB Summer: & 89.43 & 7.43 & $5,038,710$ & $38,290,000$ & 7.60 \\
Illinois\#6 Summer: & 86.31 & 4.31 & $4,721,236$ & $29,719,000$ & 6.29 \\
& & & & & \\
Lignite Winter: & 64.50 & 26.50 & $4,773,835$ & $27,820,000$ & 5.83 \\
BZap Winter: & 59.03 & 21.03 & $5,053,996$ & $24,929,000$ & 4.93 \\
PRB Winter: & 57.50 & 19.50 & $5,008,234$ & $23,340,000$ & 4.66 \\
Illinois\#6 Winter: & 50.96 & 12.96 & $4,680,329$ & $17,205,000$ & 3.68 \\
\hline
\end{tabular}

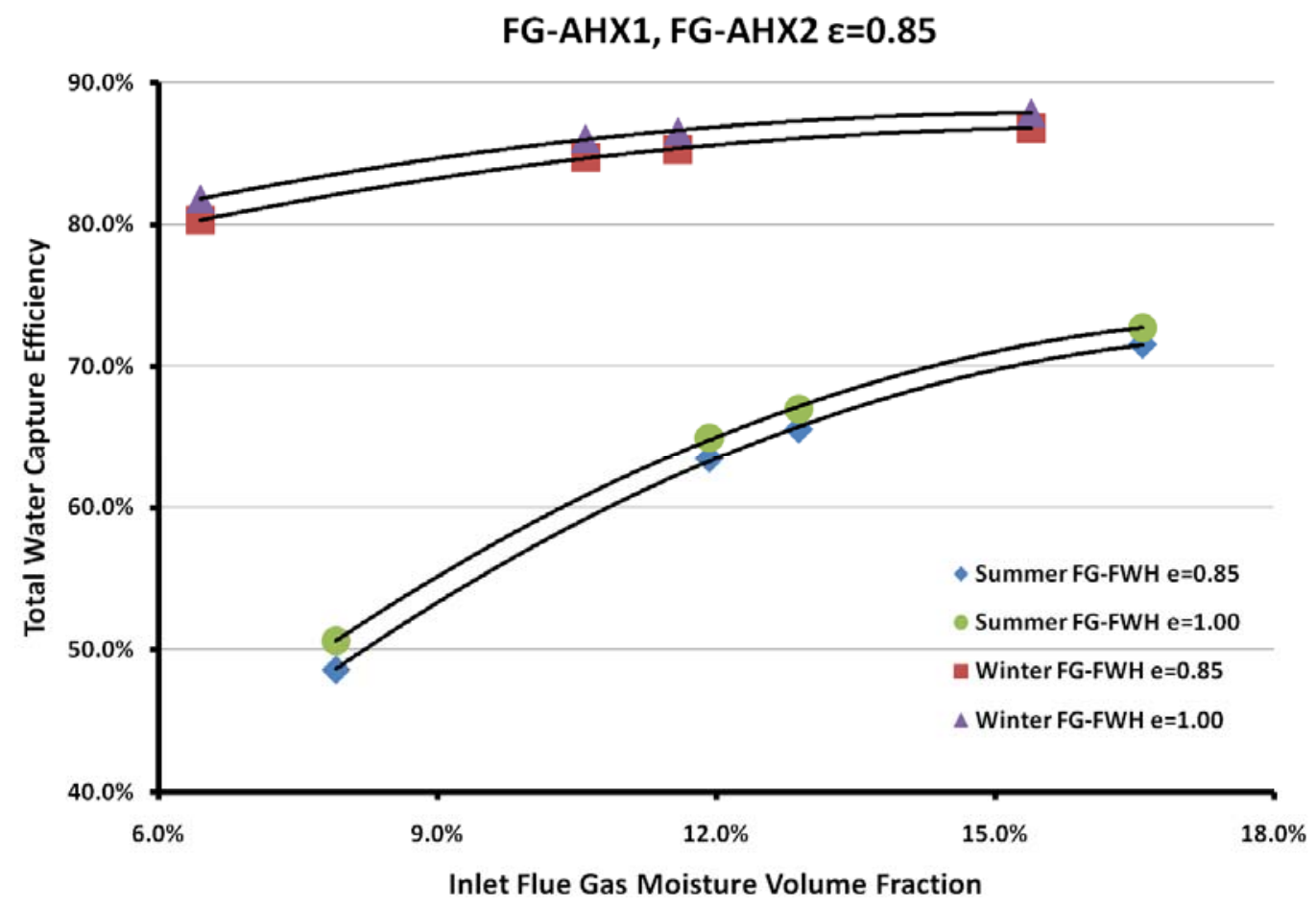

Figure 6-25: Total Water Capture Efficiency as a Function of Inlet Flue Gas Moisture Fraction for Summer and Winter Conditions. 


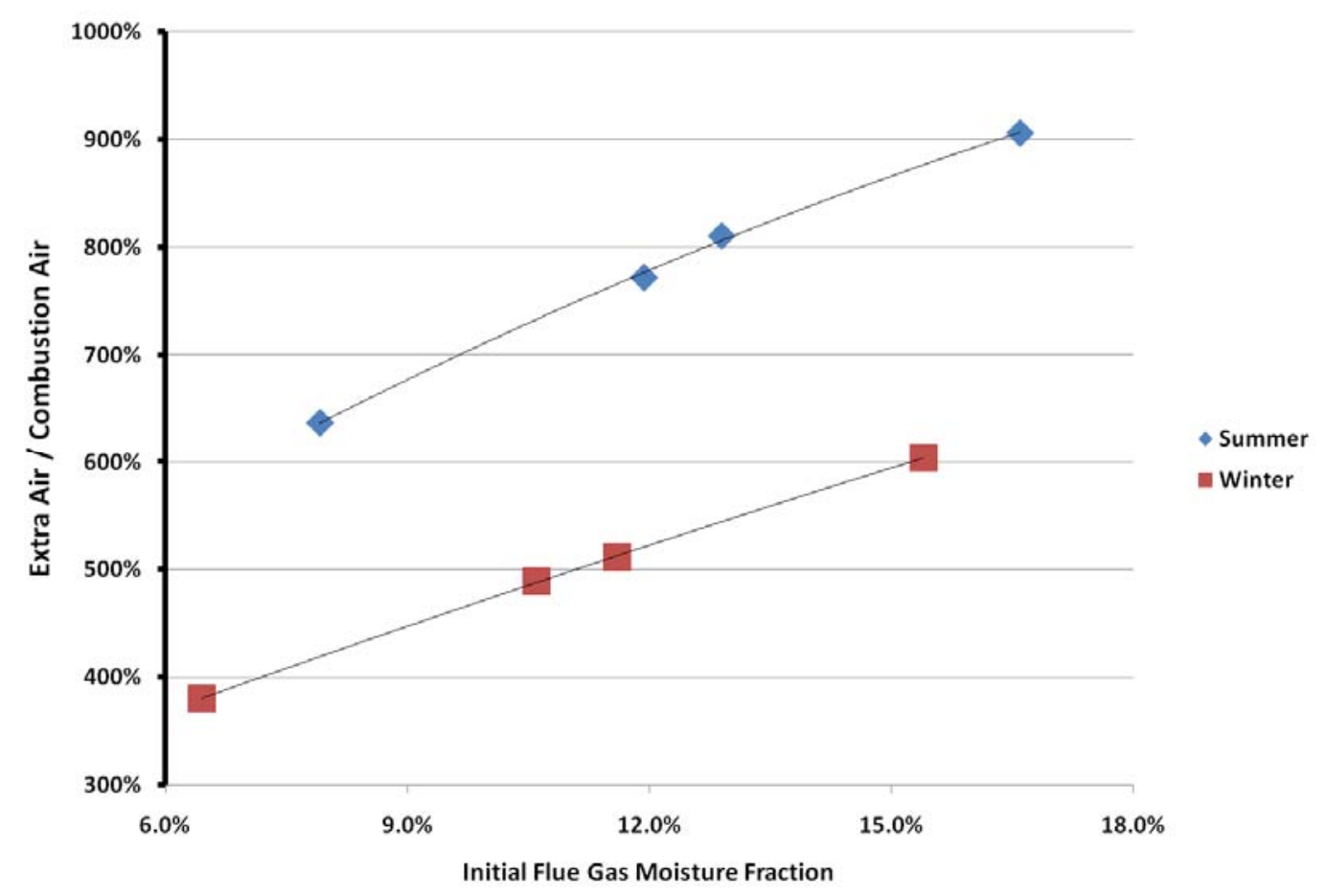

Figure 6-26: Ratio of Cooling Air Mass Flow Rate for AHX2 to Combustion Air Mass Flow Rate.

\section{ESTIMATED FRACTION OF COOLING TOWER MAKEUP WATER PROVIDED BY SYSTEM OF CONDENSING HEAT EXCHANGERS}

An analysis was carried out to estimate the fraction of cooling tower makeup water which could be provided by extracting moisture from flue gas using a system of condensing heat exchangers. The annual average cooling tower water consumption in the U.S. is 0.426 gallons/kWh (Ref. 1). As noted in Chapter 1 of this report, if all of the flue gas moisture could be recovered and used for cooling tower makeup water, depending on coal moisture content, this would represent anywhere from approximately 10 to 29 percent of the makeup water. Table 6-7 lists, for a unit with a net power output of $585 \mathrm{MW}$, the predicted summer and winter water capture efficiencies and the mass flow rates of captured flue gas water from the combined three groups of heat exchangers. The resulting ratios of captured flue gas water vapor to annual average cooling tower makeup water needs is shown in Figure 6-27. These results show the estimated percentage of cooling tower makeup water needs which could be provided by condensing heat exchangers is highly dependent on flue gas moisture concentration, or equivalently on coal moisture content. The resulting numbers are 6.4 to 8.5 percent for 
typical bituminous coals, 14.1 to 16.5 percent for Powder River Basin coals and 16.1 to 24.8 percent for U.S. lignite coals.

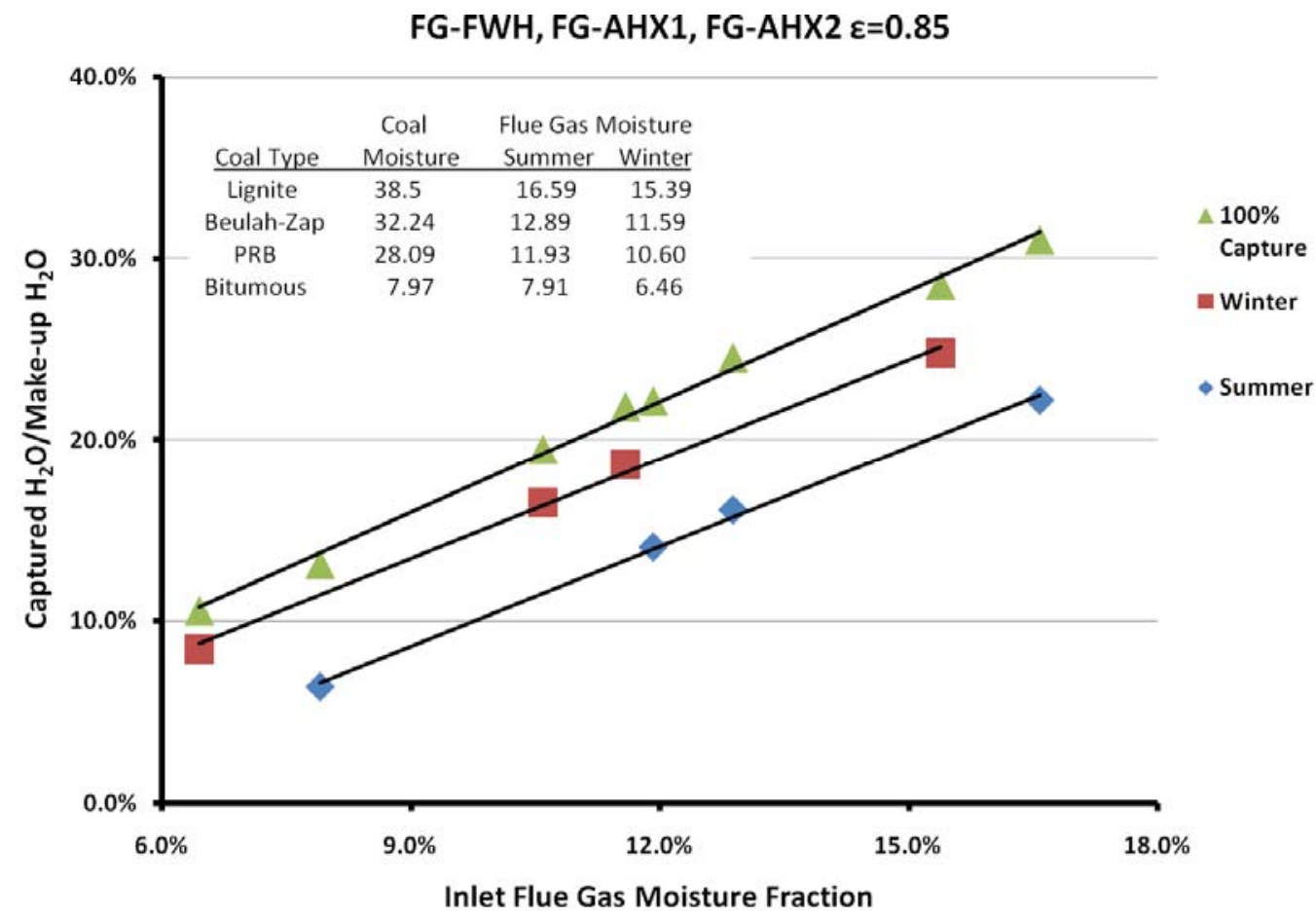

Figure 6-27: Estimated Fraction of Cooling Tower Makeup Water Provided by Condensing Heat Exchangers. 


\section{CHAPTER 7 \\ CONCLUSIONS}

The data from the pilot scale flue gas water vapor condensation tests performed in this project show that several design and process parameters affect flue gas water vapor condensation rates. Cooling water inlet temperature was found to be an important parameter, with overall water capture efficiency for a high moisture coal increasing in one case from 48 to $72 \mathrm{wt}$ percent as the inlet cooling water temperature decreased from approximately 100 to $77^{\circ} \mathrm{F}$. The overall water vapor capture efficiency was also found to be sensitive to flue gas water vapor content and as the water vapor volume fraction increased from approximately 11 to 14 percent, there were increases in overall water vapor capture efficiency of up to 10 percent. While the design of the heat exchanger system tested here was not optimized, the results suggest that water capture efficiencies greater than 70 percent will be possible for some process conditions. However, for other combinations of process conditions, much lower water capture efficiencies are to be expected. Both experimental and theoretical results show the ratio of cooling water to flue gas flow rates can have a large effect on rate of water capture, with capture efficiency decreasing steadily with a decrease in $\mathrm{m}_{\mathrm{cw}} / \mathrm{m}_{\mathrm{fg}}$ to levels of capture efficiency from 10 to 30 percent for values of $0.5<\mathrm{m}_{\mathrm{cw}} / \mathrm{m}_{\mathrm{fg}}<1.0$.

Comparisons were also made between the rates of condensation and heat transfer to the cooling water with bare tube heat exchangers and a fin tube heat exchanger in the low temperature end of the apparatus. As expected, the results show a consistent trend of higher rates of heat transfer and condensation with the fin tube heat exchanger than was obtained with the bare tube bundle. These trends are due to a larger heat exchanger surface area in the fin tube heat exchanger.

Sorbent trap measurements were made of the mercury concentrations at the inlet and outlet of the condensing heat exchanger system during coal-fired tests with cooling water inlet temperatures of $70^{\circ} \mathrm{F}$ and $100^{\circ} \mathrm{F}$. The data indicate approximately a 60 percent decrease in flue gas mercury concentration occurred due to the condensing heat exchangers. 
Measurements of sulfuric acid vapor and water vapor in the flue gas were made in both oil-fired and coal-fired tests. The regions over which the sulfuric acid and water vapor condensed were quite distinct in the oil-fired tests. The majority of the acid condensed in the high temperature heat exchanger while water vapor condensation was limited to the three low temperature heat exchangers. In contrast, acid condensation occurred within all of the heat exchangers in the coal-fired tests, with the water vapor condensation, once again, limited to the low temperature heat exchangers. The reasons for the differences between the location of sulfuric acid condensation in the coal and oil-based flue gas will be investigated by the project team in a follow-on investigation. Finally, the data also showed that hydrochloric and nitric acids condensed with water vapor in the low temperature heat exchangers.

A first-principle model of the heat and mass transfer processes occurring in the heat exchanger system was developed and used to compute both water vapor condensation rates in individual heat exchangers and the total rate of water vapor condensation. Comparisons with measured data for a range of process conditions show agreement between measurements and predictions to within a few percent. This model will make it possible to determine the effects of heat exchanger design and process conditions on water capture efficiency.

Use of heat exchangers in the back end of the boiler to recover water vapor from flue gas also provides opportunities to improve unit heat rate. Under the right conditions, sensible and latent heat transferred from the flue gas can be used to preheat boiler feedwater, thus reducing the steam turbine extraction flows to the feedwater heaters and thereby reducing unit heat rate. Other heat exchangers can be used to preheat the combustion air, thereby increasing boiler efficiency and reducing heat rate. The potential magnitude of the combined heat rate impact was determined from analyses carried out for the steam turbine cycle with an inlet feedwater temperature to the flue gas feedwater heater of $87.1^{\circ} \mathrm{F}$. The analyses were performed for four U.S. coals, ranging from a relatively low-moisture bituminous coal to a high-moisture lignite. The resulting estimated combined improvement in unit heat rate was in the 1.8 to 3.9 percent range. At the same time, the estimated combined water vapor capture 
efficiency ranged from 10 to 34 percent. Both heat rate improvement and water capture efficiency increased with increasing inlet flue gas moisture concentration, decreasing inlet combustion air temperature, and increasing heat exchanger effectiveness.

Theoretical analyses were also performed in which three separate groups of heat exchangers were used to cool the flue gas and condense flue gas moisture: one for preheating boiler feedwater, a second for preheating inlet combustion air and a third for condensing much of the remaining flue gas moisture through use of low temperature ambient air as a heat sink. For the case of high moisture North Dakota lignite, the analyses predict overall water capture efficiencies of 88 percent for winter operation and 71 percent for summer operation. Overall capture efficiency depends strongly on flue gas moisture content or equivalently on coal moisture content, and the predicted winter and summer capture efficiencies decrease to 80 percent (winter operation) and 50 percent (summer operation) for low moisture bituminous coals.

Based on U.S. annual average cooling tower makeup water needs, the estimated percentage of cooling tower makeup water which could be provided by condensing heat exchangers was found to 6.4 to 8.5 percent for units firing low moisture bituminous coals, 14.1 to 16.5 percent for units firing Powder River Basin coals and 22.2 to 24.8 percent for units firing high moisture US lignite coals.

Condensing heat exchangers can be located in different places in the flue gas path, depending on the application. For power plants with cold side ESP's or baghouses for particulate control, but without wet flue gas $\mathrm{SO}_{2}$ scrubbers (FGD), the heat exchangers would be located between the cold side ESP or baghouse and the stack. For power plants with FGD's, one heat exchanger could be located between the ESP and FGD and additional heat exchangers could be located between the FGD and stack.

There are also potential applications of condensing heat exchangers in carbon capture and sequestration systems (CCS). Amine and ammonia $\mathrm{CO}_{2}$ scrubbers require inlet flue gas temperatures below $100^{\circ} \mathrm{F}$ for efficient operation, and the types of heat 
exchangers described in this report are candidates for use in pretreating boiler flue gas before it flows into a $\mathrm{CO}_{2}$ scrubber. In addition, it is expected that in most cases the concentrated streams of $\mathrm{CO}_{2}$ produced by post-combustion $\mathrm{CO}_{2}$ scrubber systems and by oxyfuel boilers will be compressed to over 2000 psia before being transported by pipeline to geologic sequestration sites. These concentrated streams of $\mathrm{CO}_{2}$ will contain high concentrations of water vapor which should be separated from the $\mathrm{CO}_{2}$ before compression, and here, too, condensing heat exchangers of the type described in this report may have an important role to play. 


\section{APPENDIX A}

\section{HEAT EXCHANGER EFFECTIVENESS}

Heat exchanger effectiveness (Ref. 6) is defined as

$\varepsilon=\frac{\text { actual heat transfer }}{\text { maximum possible heat transfer }}$

In the case of heat exchangers in which a component of the hot fluid is condensing, the actual heat transfer should be computed by calculating the energy gained by the cold fluid.

The maximum possible heat transfer would occur if one of the fluids were to undergo a temperature change equal to the difference in temperatures of the entering hot and cold fluids. The fluid which might undergo this maximum temperature difference is the one having the smaller of the two values of $m \times c_{p}$ since conservation of energy requires that the energy given up by the hot fluid must equal the energy received by the cold fluid. For this reason, if the fluid with the larger value of $m \times c_{p}$ were to go through the maximum temperature difference, this would require that the other fluid undergo a temperature difference greater than the maximum, which would violate conservation of energy.

In heat exchangers which use boiler feedwater as the heat sink and which operate with tube wall temperatures above the flue gas water vapor dewpoint temperature, the maximum rate of heat transfer is

$$
Q_{\max }=m_{g} \times C p_{g} \times\left(T_{\text {gin }}-T_{\text {win }}\right)
$$

In heat exchangers which use boiler feedwater as the heat sink and which operate with tube wall temperatures both above and below the flue gas water vapor dewpoint temperature, there is both sensible and latent heat transfer. As a result, 


$$
Q_{\max }=m_{g} \times C p_{g} \times\left(T_{\text {gin }}-T_{\text {dew }}\right)+m_{f w} \times c_{w} \times\left(T_{\text {dew }}-T_{w \text { in }}\right)
$$

In the case of heat exchangers cooled by combustion air with condensation occurring over the entire length of the heat exchanger,

$$
Q_{\max }=(m C p)_{C A} x\left(T_{\text {gin }}-T_{C A} \text { in }\right)
$$

In the case of heat exchangers cooled by air having a flow rate significantly greater than the flue gas flow rate and with condensation occurring over the entire length of the heat exchanger,

$$
Q_{\max }=h_{L} \times\left[m_{g w, i n}-m_{g w}\left(T_{A H X 2, \text { in }}\right)\right]+m_{g} \times C p_{g}\left(T_{g i n}-T_{A H X 2, \text { in }}\right)
$$




\section{REFERENCES}

1. "Estimating Freshwater Needs to Meet Future Thermoelectric Generation Requirements: 2007 Update," DOE/NETL Report 400/2007/1304, September 24, 2007.

2. DeVito, M. S. and D. L. Smith, "Controlled Condensation Method: New Option for $\mathrm{SO}_{3}$ Sampling," Power, February 1991, pp. 41-44.

3. CFR 40, Part 75, Appendix K, "Quality Assurance and Operation Precedures for Sorbent Trap Monitoring Systems"

4. Verhoff, F. H. and J. T. Banchero, "Predicting Dew Points of Flue Gases," Chem. Eng. Progress, 1974, Vol. 70, pp. 71-72.

5. Yen Hsiung Kiang, "Predicting Dewpoints of Acid Gases," Chemical Engineering, February 9, 1981, p. 127.

6. J. P. Holman, Heat Transfer, McGraw Hill, 1963. 


\begin{tabular}{|c|c|}
\hline A & Heat Exchanger Surface Area \\
\hline$A_{85}$ & Heat Exchanger Surface Area for 85 Percent Effectiveness \\
\hline $\mathrm{C}_{\mathrm{H} 2 \mathrm{O}}$ & Flue Gas Water Vapor Concentration \\
\hline $\mathrm{Cp}_{\mathrm{g}}$ & Specific Heat of Flue Gas \\
\hline $\mathrm{C}_{\mathrm{w}}$ & Specific Heat of Liquid Phase Water \\
\hline FGET & Flue Gas Exit Temperature \\
\hline FGET & Flue Gas Temperature Exiting FG-AHX2 \\
\hline$h_{f g}$ or $h_{L}$ & Latent Heat of Evaporation \\
\hline $\mathrm{m}_{\mathrm{AHX} 2}$ & Flow Rate of Cooling Air Through AHX2 \\
\hline $\mathrm{M}_{\mathrm{C}}$ or $\mathrm{M}_{\mathrm{CD}}$ & Rate of Water Vapor Condensation \\
\hline $\mathrm{m}_{\mathrm{CA}}$ & Flow Rate of Combustion Air \\
\hline $\mathrm{m}_{\mathrm{cw}}$ & Mass Flow Rate of Cooling Water \\
\hline $\mathrm{M}_{\mathrm{fg}}$ or $\mathrm{M}_{\mathrm{g}}$ & Mass Flow Rate of Flue Gas \\
\hline$m_{\mathrm{fw}}$ & Flow Rate of Boiler Feedwater \\
\hline 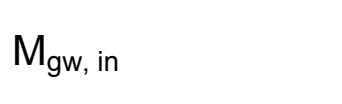 & $\begin{array}{l}\text { Mass Flow Rate of Water Vapor in Flue Gas at Heat } \\
\text { Exchanger Inlet }\end{array}$ \\
\hline $\mathrm{M}_{\mathrm{gw}}\left(\mathrm{T}_{\mathrm{AHX} 2, \mathrm{in}}\right)$ & $\begin{array}{l}\text { Mass Flow Rate of Water Vapor in Flue Gas with Flue Gas } \\
\text { Temperature Equal to Cooling Air Inlet Temperature }\end{array}$ \\
\hline QLATEnt or $Q_{L}$ & Rate of Latent Heat Transfer \\
\hline$Q_{\text {sensible }}$ or $Q_{s}$ & Rate of Sensible Heat Transfer \\
\hline $\mathrm{T}_{\mathrm{AH} \times 2 \text {, in }}$ & Inlet Temperature of Cooling Air \\
\hline $\mathrm{T}_{\text {ambient }}$ & Ambient Air Temperature \\
\hline $\mathrm{T}_{\mathrm{cw}}$ & Cooling Water Temperature \\
\hline $\mathrm{T}_{\mathrm{cw}, \text { in }}$ & Inlet Cooling Water Temperature \\
\hline $\mathrm{T}_{\text {dew }}$ & Water Vapor Dew Point Temperature \\
\hline $\mathrm{T}_{\mathrm{fw}}$ & Feedwater Temperature \\
\hline$T_{\mathrm{fw}}$, in & Inlet Feedwater Temperature \\
\hline$T_{G}$ or $T_{g}$ & $\begin{array}{l}\text { Flue Gas Temperature } \\
\text { Volumetric Concentration of Water Vapor in Flue Gas }\end{array}$ \\
\hline $\mathrm{y}_{\mathrm{FWH}}, \mathrm{y}_{\mathrm{AHX} 1}, \mathrm{y}_{\mathrm{AHX}} 2$ & $\begin{array}{l}\text { Water Vapor Concentrations at Exits of Individual Heat } \\
\text { Exchangers }\end{array}$ \\
\hline$\varepsilon$ & Heat Exchanger Effectiveness (See Appendix A) \\
\hline$\eta_{w c}$ & Water Capture Efficiency \\
\hline$\Delta \mathrm{T} 2$ & FEGT - $T_{\text {ambient }}$ \\
\hline
\end{tabular}




\section{ACRONYMS AND DEFINITIONS}

$\begin{array}{ll}\text { APH } & \text { Air Preheater } \\ \text { ASPEN Plus } & \text { Process Modeling Software } \\ \text { Beulah-Zap } & \text { North Dakota Lignite with Approximately 32 Percent Moisture } \\ \text { BFP } & \text { Boiler Feed Pump } \\ \text { ESP } & \text { Electrostatic Precipitator } \\ \text { FGD } & \text { Flue Gas Desulfurization Equipment } \\ \text { FG-AHX1 } & \text { Condensing Heat Exchanger Using Combustion Air as Heat Sink } \\ \text { FG-AHX2 } & \text { Condensing Heat Exchanger Using Ambient Air as Heat Sink } \\ \text { FG-FWH } & \text { Feedwater Heater Using Flue Gas as Heat Source } \\ \text { FWH } & \text { Feedwater Heater } \\ \text { HX } & \text { Heat Exchanger } \\ \text { HP Turbine } & \text { High Pressure Turbine } \\ \text { IP Turbine } & \text { Intermediate Pressure Turbine } \\ \text { LP Turbine } & \text { Low Pressure Turbine } \\ \text { PRB } & \text { Powder River Basin Coal } \\ \text { W } & \text { Power }\end{array}$

